\title{
SOEP
}

SOEPpapers

on Multidisciplinary Panel Data Research

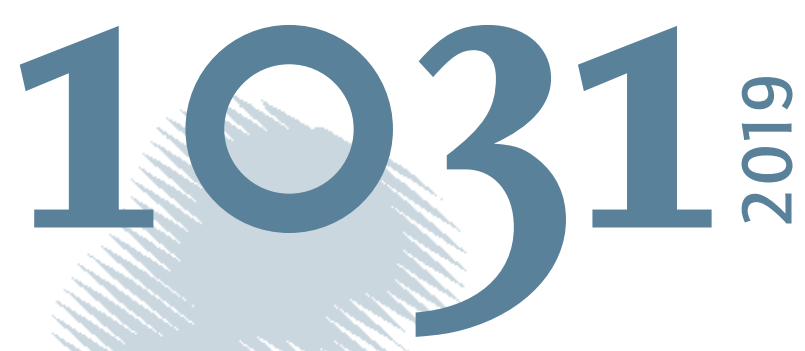

\section{Undoing Gender with Institutions. Lessons from the German Division and Reunification}


This series presents research findings based either directly on data from the German SocioEconomic Panel study (SOEP) or using SOEP data as part of an internationally comparable data set (e.g. CNEF, ECHP, LIS, LWS, CHER/PACO). SOEP is a truly multidisciplinary household panel study covering a wide range of social and behavioral sciences: economics, sociology, psychology, survey methodology, econometrics and applied statistics, educational science, political science, public health, behavioral genetics, demography, geography, and sport science.

The decision to publish a submission in SOEPpapers is made by a board of editors chosen by the DIW Berlin to represent the wide range of disciplines covered by SOEP. There is no external referee process and papers are either accepted or rejected without revision. Papers appear in this series as works in progress and may also appear elsewhere. They often represent preliminary studies and are circulated to encourage discussion. Citation of such a paper should account for its provisional character. A revised version may be requested from the author directly.

Any opinions expressed in this series are those of the author(s) and not those of DIW Berlin. Research disseminated by DIW Berlin may include views on public policy issues, but the institute itself takes no institutional policy positions.

The SOEPpapers are available at http://www.diw.de/soeppapers

\section{Editors:}

Jan Goebel (Spatial Economics)

Stefan Liebig (Sociology)

David Richter (Psychology)

Carsten Schröder (Public Economics)

Jürgen Schupp (Sociology)

Conchita D'Ambrosio (Public Economics, DIW Research Fellow)

Denis Gerstorf (Psychology, DIW Research Fellow)

Elke Holst (Gender Studies, DIW Research Director)

Martin Kroh (Political Science, Survey Methodology)

Jörg-Peter Schräpler (Survey Methodology, DIW Research Fellow)

Thomas Siedler (Empirical Economics, DIW Research Fellow)

C. Katharina Spieß (Education and Family Economics)

Gert G. Wagner (Social Sciences)

ISSN: 1864-6689 (online)

German Socio-Economic Panel (SOEP)

DIW Berlin

Mohrenstrasse 58

10117 Berlin, Germany

Contact: soeppapers@diw.de

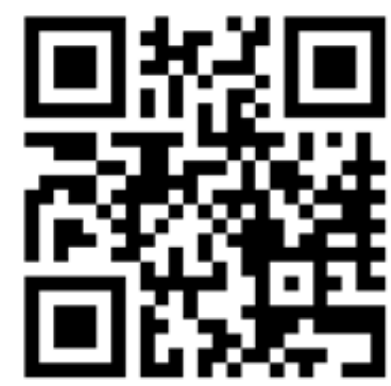




\title{
Undoing Gender with Institutions. Lessons from the
}

\section{German Division and Reunification.}

\author{
Quentin Lippmann, Alexandre Georgieff, and Claudia Senik*†
}

\begin{abstract}
Using the 41-year division of Germany as a natural experiment, we show that the GDR's gender-equal institutions created a culture that has undone the male breadwinner norm and its consequences. Since reunification, East Germany still differs from West Germany not only by a higher female contribution to household income, but also because East German women can earn more than their husbands without having to increase their number of housework hours, put their marriage at risk or withdraw from the labor market. By contrast, the norm of higher male income, and its consequences, are still prevalent in West Germany.
\end{abstract}

JEL codes: D13, I31, J16, P51, Z1

Keywords: Gender norms, Culture, Institutions, German division, Family, Housework, Divorce, Labor market.

\footnotetext{
${ }^{*}$ Corresponding author: at Paris School of Economics, 48 Boulevard Jourdan 75014 Paris, senik@pse.ens.fr

${ }^{\dagger}$ We thank CEPREMAP and the French National Research Agency, through the program Investissements d'Avenir, ANR-10-LABX-93-01, for financial support. We are grateful to participants in seminars at the Paris School of Economics, Sciences Po, Columbia University, Cornell University, Duke University, NYU, Dartmouth College, at the LAGV and IAREP 2016 Conferences, for useful comments. The paper also benefitted from remarks from Pierre-André Chiappori, Sergei Guriev, Nicolas Jacquemet, Rachel Kranton, Erzo Luttmer, Marjorie McElroy, Petra Moser, Michael Peters, Jean-Marc Robin, Martin Rotemberg, Odile Rouhban, Anne Solaz, Kevin Thom, Mallika Thomas, Na'ama Shenhav, Jon Skinner and Ekaterina Zhuravskaya, as well as two anonymous referees and the editor. Alexandre Georgieff worked on this paper while he was at the Paris School of Economics. The opinions expressed in this paper are those of the authors and cannot be attributed to the OECD or its Member Countries. The errors naturally remain ours.
} 
Men spend more time in paid work, and women more time in housework. In spite of the rise in female participation in the labor market and the feminist struggle for greater symmetry, this gender-wise specialization within couples remains a quasi-universal norm. As a consequence, gender gaps in labor force participation and earnings have not subsided (Bertrand et al., 2015; Blau and Kahn, 2017) and the male breadwinner model remains prevalent.

What is the rationale for the stability of this pattern? Household economists have proposed various explanations based on the notion of comparative advantage (Becker, 1973, 1974), with or without bargaining between spouses (Chiappori, 1988, 1992; Weiss, 1997). These comparative advantages can be seen in turn as partly natural or as being dictated by the nature of economic activity and job characteristics at each stage of a society's development (Alesina et al., 2013; Autor et al., 2003; Beaudry and Lewis, 2014; Black and Spitz-Oener, 2010). Institutions also certainly play a role in designing the architecture of choices for men and women, and providing incentives for more or less specialization (Esping-Andersen, 2009).

On top of these potential determinants, social scientists have pointed out the superimposition of norms (Akerlof and Kranton, 2000, 2013), postulating that people may attach some value to the roles they endorse per se, such as gender roles. An entire set of stylized facts that cannot be rationalized within standard economic models comes in support of this idea. One of the most striking of these observations is the reaction of households when the male breadwinner norm is violated. While any economic model of decision-making within the family would predict that a spouse should decrease her number of housework hours as her personal contribution to the household income increases, empirical evidence shows that things are not so simple. Beyond spouses' income equality threshold, when a woman becomes the primary breadwinner, she starts doing gender (West and Zimmerman, 1987) by increasing her number of housework hours, and sometimes withdrawing from the labor force. Such marriages also become more unstable. ${ }^{1}$

\footnotetext{
${ }^{1}$ See Greenstein (2000), Akerlof and Kranton (2000), Bittman et al. (2003), Evertsson and Nermo (2004) and Schneider (2011) on housework, Heckert et al. (1998), Jalovaara (2003) and Liu and Vikat
} 
It would be difficult to make sense of such behaviors without recourse to the notion of gender identity. Existing studies have mostly contributed to establishing the existence of this gender-unequal norm, but little is known about its origin and the part played by public policy in constructing or deconstructing it.

This paper brings the first causal evidence that the male breadwinner norm is cultural and can be undone by institutions. Developing a causal test of the role of institutions is a major empirical challenge. Specifically, gender-equalizing institutions are much more likely to emerge in an environment where mentalities have already become more gender friendly. To overcome this empirical hurdle, we focus on Germany and exploit the natural experiment constituted by the 41-year division of the country. Before World War II, prior to the division, gender norms, including female labor force participation, were essentially similar in Eastern and Western regions. During the division, East Germany adopted gender-equalizing policies, in line with the universal "right" (and obligation) to work. Work-family balance programs, kindergarten and other childcare facilities were put in place (Bauernschuster and Rainer, 2012). In the meantime, a traditional family policy prevailed in West Germany. The institutions and policies implemented in the two regions radically diverged and so did gender roles. As a result, in 1989, women's labor force participation in the German Democratic Republic (GDR) had reached about 89\%, one of the highest in the world, against $56 \%$ in West Germany (Rosenfeld et al., 2004). After reunification, the government of the former Federal Republic of Germany (FRG) took over East Germany and rapidly dissolved its institutions and structures and absorbed them into those of West Germany, which remained unchanged.

Using data from the German Socio-Economic Panel from 1991 to 2012, we establish that, since reunification, the male breadwinner norm has been prevalent in West Germany but not in the East. First, we show that women who earn more than their husbands "compensate" by increasing their number of housework hours in West Germany. But this is not the case in East Germany, where women monotonically keep decreasing the (2004), on the risk of divorce, and Bertrand et al. (2015) on the three types of consequences. 
time they spend on housework as their contribution to the household finances rises. Consistently, in West Germany, the risk of divorce increases for couples where the wife switches from earning less to earning more than her husband, whereas this is not the case in East Germany. Finally, we show that when a woman's potential income is higher than that of her husband, she is more likely to withdraw from the labor market, but only in West Germany. Likewise, when a West German woman actually starts earning more than her husband, she is more likely to withdraw from the labor market in the following year. These behaviors are mirrored by self-reported preferences, as East German women attach almost as much value to paid work as men, in contrast with West German women.

To demonstrate the robustness of our results, we run systematic placebo exercises to establish that it is the focal point of equal incomes that triggers these reactions, and not any other alternative cut-off point. Similarly, we show that it is the former Berlin wall that constitutes the dividing line, and not any other division of Germany. We also provide substantive evidence showing that our results do not stem from pre-existing or current differences between Eastern and Western regions. First, we show that before the division, Eastern and Western regions had similar industrial, employment and social structures: we show this using first-hand statistical sources pertaining to the year 1933, as well as Prussian data from 1886 and 1849. We also illustrate the diverging trends in terms of female labor market participation. Second, we rule out the suspicion that East-West differences in household behavior could be due to other historical differences in unobservables or persisting structural differences, such as economic conditions. To do so, we focus on areas where it is likely that people face the same structural conditions. We show that among couples who currently live in the West, i.e. in the same environment, those who migrated from the East after 1990 display much more egalitarian behavior in terms of female labor market participation, wage earnings and housework time. In the same spirit, we use another survey (GoGold) to show that among women who currently live in East or West Berlin, those who were born in a former socialist country, or whose mother was born in a former socialist country, are much more likely to be working full 
time (ceteris paribus) than those who were not. We also focus on couples who live near the former East-West border and document the sharp spatial discontinuity of the female contribution to household income at the border and re-establish our main results on this subsample. Finally, we exploit the heterogeneity within West Germany to rule out the suspicion that our findings may be driven by wage structure differentials.

These results shed light on the sources of gender inequality. After decades of progress, female labor force participation has recently plateaued (Blau and Kahn, 2017) and researchers have started to investigate the determinants of social norms influencing gender equality. These include technological changes (Goldin and Katz, 2002), the influence of ancestors (Fernández et al., 2004; Fernandez and Fogli, 2009), information (Alessandra and Laura, 2011) and past technology (Alesina et al., 2013). We add to this literature by considering the role of institutions in sustaining the male breadwinner norm.

Our results are directly related to the literature on social norms and preferences, beyond gender issues. Experiments in behavioral economics have shown that, in dictator games for instance, the situation of equal earnings is a focal point that powerfully influences decisions (Rabin, 1993; Charness and Rabin, 2002). Cultural economics has also shed light on the evolution of social norms (Bisin and Verdier, 2001, 2011; Alesina and Giuliano, 2015; Fernández, 2013). Here, we illustrate the influence of institutions on social norms and identity.

This paper is in the line of Alesina and Fuchs-Schündeln (2007) who exploited the same episode of socialism in Germany to study the lasting (and progressively withering) effect of socialist institutions on mentalities. Regarding gender attitudes, several studies, such as Breen and Cooke (2005), Bauernschuster and Rainer (2012) or Beblo and Görges (2014) have illustrated the smaller gender gap in East Germany, as compared with West Germany, in terms of self-reported attachment to work. Campa and Serafinelli (2016) show that this appears to be a hallmark of socialist states. Besides work attitudes, Lippmann and Senik (2018) have also shown that the gender gap in mathematics is smaller in East Germany and in former socialist countries.. 
The rest of this work is organized as follows. Section 1 recalls the institutional background of East and West Germany. Section 2 describes the data. Section 3 presents the empirical strategy. Section 4 studies the impact of higher female earnings on housework hours, the risk of divorce, and female labor market participation. Section 5 provides robustness checks. Section 6 illustrates the differences in work attitudes among Western and Eastern couples. Section 7 concludes.

\section{The German Division as a Natural Experiment}

\subsection{Before the Division}

The division of Germany was drawn by a postwar agreement between the Allies, on the basis of the zones occupied by the Soviet Union and Western countries. In 1949, five Länder formed the GDR and the remaining eleven constituted the FRG. The line of division was thus arguably unrelated to pre-existing differences between the two regions.

To provide evidence on this matter, we collected data from German statistical yearbooks before the division. Table 1 describes the situation in $1933 .{ }^{2}$ Columns 1 and 2 provide descriptive statistics for the Eastern and Western regions of Germany. Column 3 computes the differences between the two regions. In 1933, the employment structure was similar in the two regions. About $45 \%$ of East Germans worked in industry against $40 \%$ in the West. As regards gender behavior, the table shows that the female share of employment was 2.8 percentage points higher in the East, and the birth rate (per thousand) 1.95 points higher in the West.

\footnotetext{
${ }^{2}$ In the Appendix Table B1, we replicate the same exercise using data from the 19th century in 1886 and 1849. Similarly, we find that there was very little differences between East and West Germany in the 19th century.
} 
Table 1: East and West Germany in 1933. Descriptive Statistics

\begin{tabular}{|c|c|c|c|c|c|}
\hline & $\begin{array}{c}\text { East } \\
(1)\end{array}$ & $\begin{array}{c}\text { West } \\
(2)\end{array}$ & $\mid$ East-West $\mid$ & $\begin{array}{c}\text { Average } \\
\text { Regional } \\
\text { Differences } \\
(4)\end{array}$ & P-value \\
\hline Industry and Handcraft \% & 44.64 & 40.08 & 4.55 & $\begin{array}{c}4.69 \\
(2.92)\end{array}$ & 0.47 \\
\hline Retail and Transport \% & 16.32 & 16.65 & 0.33 & $\begin{array}{c}2.05 \\
(1.77)\end{array}$ & 0.89 \\
\hline Agriculture \% & 16.01 & 21.21 & 5.20 & $\begin{array}{c}5.79 \\
(3.66)\end{array}$ & 0.51 \\
\hline Services\% & 9.10 & 9.60 & 0.51 & $\begin{array}{c}0.49 \\
(0.46)\end{array}$ & 0.66 \\
\hline Free occ. / Self-employed \% & 13.95 & 12.98 & 0.97 & $\begin{array}{c}0.66 \\
(0.49)\end{array}$ & 0.12 \\
\hline Female share of employees** $\%$ & 35.92 & 33.12 & 2.80 & $\begin{array}{c}2.94 \\
(1.91)\end{array}$ & 0.46 \\
\hline Female share of high school students\% & 31.61 & 34.87 & 3.26 & $\begin{array}{c}2.32 \\
(1.57)\end{array}$ & 0.28 \\
\hline Marriages per 1000 inhabitants & 9.87 & 9.45 & 0.42 & $\begin{array}{c}0.52 \\
(0.34)\end{array}$ & 0.57 \\
\hline Births per 1000 inhabitants & 13.02 & 14.97 & 1.95 & $\begin{array}{c}1.02 \\
(0.78)\end{array}$ & 0.15 \\
\hline Population (in Millions) & 11.43 & 35.44 & & & \\
\hline
\end{tabular}

Notes: Own calculations based on Statistisches Reichsamt (1936:27, 37, 1935:297) for 1933. We use the regions of the former German Empire that coincide with the later boundaries of GDR and FRG, excluding Berlin. East: Anhalt, Mecklenburg, Prov. Sachsen, Sachsen, Thüringen. West: Baden, Bayern, Bremen, Hamburg, Hessen, Hohenzollerische Lande, Lippe, Lübeck, Oldenburg, Prov. Hannover, Prov. Hessen-Nassau, Prov. Westfalen, Rheinprovinz, Schaumburg-Lippe, Württemberg. ** For these statistics, the divide is based on the State Employment Office Districts, i.e. for GDR: Mitteldeutschland, Sachsen, and for FRG: Bayern, Hessen, Niedersachsen, Rheinland, Sudwestdeutschland, Westfalen. Column (4) displays the average absolute value of differences between regions in all possible regional partitions of 20 regions into $5+15$, as well as the standard error of these averages in parenthesis. Column (5) displays the probability that these differences are higher than the East/West difference displayed in column (3), which corresponds to the share of these differences that is higher than the East/West difference. In row 6 (female share of employees), the calculation was made on the basis on the 8 regions available in official statistics (instead of 20). In row 7 (female share of high school students), data are missing for Schaumburg-Lippe, and the resulting number of available Länder is 19 .

How did the small East/West differences compare with the average regional differences? To investigate this question, we performed a permutation test that follows the 
logic of a Fisher exact test, and compared, for each measure, the East-West difference with the picture that would emerge from any random partition of Germany (excluding Berlin) into two groups of respectively 15 and 5 regions (column 5). It turns out that in 1933, the structural dissimilarities between the two regions that would later become East Germany and West Germany (excluding Berlin) were not any different from what would stem from any random division of the 20 regions into two groups of $5+15$ regions. This is attested by the p-value (column 5). This result supports the idea that the division of Germany was not influenced by pre-existing regional differences.

\subsection{Diverging Trends during the Division}

After the division, between 1949 and 1990, the GDR rapidly set up institutions in favor of gender equality. Beyond its constitution ensuring full equality between men and women, the Mother and Child Care and Women's Rights Acts, adopted in 1950, aimed at '[establishing] a range of social services in support of full female employment, including a network of public childcare centers, kindergartens and facilities for free school meals' (Cooke, 2007, p. 935), as well as paid maternity leave. By 1972, additional policies expanded childcare facilities and extended paid maternity leave to 18 weeks. A final set of reforms implemented between 1972 and 1989 improved childcare facilities, extended parental leave to 20 weeks and allowed fathers as well as grandmothers to take this leave (Cooke, 2007). In summary, these policies were targeted at making participation in the labor force compatible with maternity (see Goldstein and Kreyenfeld, 2011 about fertility trends in both regions).

In the meantime, the FRG's policies strengthened the traditional family model. Irregular school schedules and scarce childcare facilities inhibited female employment. The tax system favored single earner families, as non-employed spouses and children could get public health insurance at no extra cost. Until 1977, the Marriage and Family law stated that: "The wife is responsible for running the household. She has the right to be employed as far as this is compatible with her marriage and family duties' (Civil Code 
on the Effects of Marriage in General, title Five, Section 1356). ${ }^{3}$ Subsequent policies then alternated more or less conservative incentives for female participation in the labor market.

As a result of these very different policies, the female labor market participation rate started to diverge after the division. To illustrate the impact of the two different sets of policies during the division, we collected data from statistical yearbooks from 1959 to 1987. Figure 1 displays the diverging trends of women's share in total employment. In the FRG, the share of employed women, as a percentage of the total female population remains steadily around 30\%, whereas in the GDR, it rises from approximately the same level to 50\% between 1959 and 1987 (the years for which these statistics are available). ${ }^{4}$

Figure 1: Evolution of Women's Participation in the Labor Market

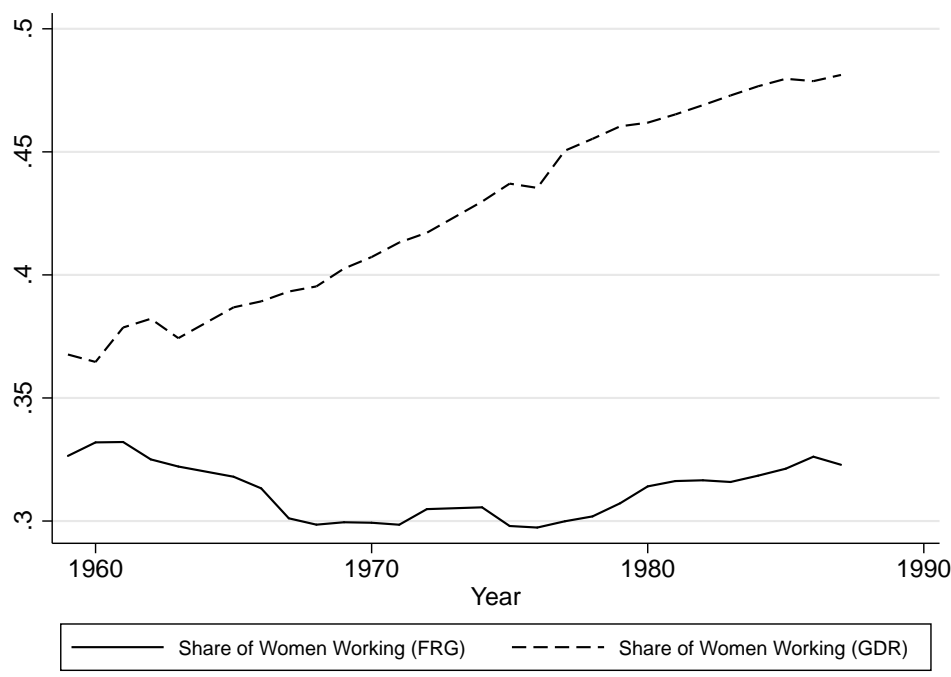

Notes: Authors' computation using the statistical yearbooks of FRG and GDR from 1959 to 1987. The shares of working women are computed by dividing the number of working women by the total number of women in the population. We do not report data for years prior to 1959 because self-employed starts being included in the number of workers from 1959 only, making longer time series inconsistent.

\footnotetext{
${ }^{3}$ See also Rheinstein and Glendon (1978).

${ }^{4}$ These diverging trends happened notwithstanding migration. Cornelius and Tsuda (2004) reports that 730,000 Germans moved from the Soviet zone to the other zones in the late 1940s, and another 3.8 million moved from East Germany to West Germany between 1949 and the building of the Berlin Wall in August 1961; then only 600,000 Germans moved West between 1961 and 1988.
} 


\subsection{Persisting Differences after Reunification}

After reunification, the government of the former Federal Republic of Germany (FRG) took over East Germany and rapidly dissolved its institutions and structures, absorbing them into those of West Germany, which remained unchanged. Yet, persisting differences between the two regions were still observable ten years later in 2000. Labor force participation was still approximately the same across gender in the former GDR (around $80 \%$ ), whereas the gap remained wide in West Germany, with $65 \%$ of women in the labor force against $81 \%$ of men (Schenk, 2003). As we will show, these objective differences are supported by opinions regarding gender roles. In terms of paid work time, in 2000, East German workers generally worked longer hours than West Germans: 35 hours for women and 42 hours for men in the former GDR against respectively 29 and 40 hours in the former FRG. This is probably a legacy of the different labor laws that prevailed during the division. ${ }^{5}$ The status of part-time employment also differed considerably across regions. In West Germany, part-time workers, most of whom were women, often worked less than 20 hours, and were not eligible for the same social benefits as full-time workers (Rosenfeld et al., 2004). In East Germany, part-time workers had longer hours, received identical social benefits and used these contracts primarily as a transition to retirement.

This does not mean that there are no gender differences at all in East Germany. For instance, Rosenfeld et al. (2004), document the existence of gender wage gaps and occupational segregation. Additionally, within the household, although men participate more in housework in the East than in the West, Eastern women still take on a greater share of housework (Cooke, 2007).

\footnotetext{
${ }^{5}$ The standard regulatory full-time number of work hours per week was 43.75 in the GDR against 36 to 39 in the FRG (Rosenfeld et al., 2004.)
} 


\section{Data}

\subsection{Source}

We use the German Socio-Economic Panel, a longitudinal survey run by the German Institute for Economic Research (DIW, Berlin). ${ }^{6}$ This survey was started in 1984 in West Germany and was extended to East Germany in 1990. In 1998, 2000, 2002, 2006, 2009, 2011 and 2012, additional German households were added to the initial sample. We use 22 waves, from 1991 to 2012.

\subsection{Main Explanatory Variables}

East versus West. Our exercise consists in contrasting the behavior of East versus West Germans. We exploit the biographical information contained in the dataset. The questionnaire asked all individuals: "Where did you live before 1989?". We define an East dummy variable that takes the value 1 (0) if both spouses lived in GDR (FRG) before 1989, independently of where they live at the time of the survey. ${ }^{7}$

Relative Income. Our main explanatory variable is a dummy that equals 1 if the wife earns more than her husband and 0 otherwise (hereafter: WifeEarnsMore), where income measures monthly labor earnings.

\subsection{Main Outcomes}

Housework. The time spent on housework is measured using the following question: "What is a typical weekday like for you? How many hours per normal workday do you spend on housework (washing, cooking, cleaning)?". The definition of housework, i.e. the list of tasks included in the survey, follows the general usage in the literature. In

\footnotetext{
${ }^{6}$ Socio-Economic Panel (SOEP), data for years 1984-2012, version 29, SOEP, 2013. For more details, see Goebel et al., 2018.

${ }^{7}$ This definition excludes mixed couples where one spouse originates from GDR and the other from FRG. For robustness, we also included this type of couple and define an East dummy variable that takes the value $1(0)$ if only one spouse lived in GDR (FRG) before 1989. We performed this robustness check using successively the origin of the wife and of the husband. The results remained similar.
} 
particular, it does not include the time parents spend with children. The norm concerning childcare has changed since the 1970s: a new norm of intensive parenting has diffused, whereby the time spent with children is more and more considered as leisure. This is particularly true of more educated parents and wealthier families (Sullivan, 2010). For this reason, we leave this aspect of couples' time-use aside from our main housework measure.

Divorce. In Section 4.2, we look at the impact of female relative income on the risk of divorce. We consider the sample of married working couples, aged 18 to 65 years old, and estimate the likelihood of divorce within the coming years, according to their relative income. We use the marital status reported by both spouses at each wave, as well as the biographic data file. As divorce takes time, our main variable of interest is the risk of divorce in a 5-year horizon.

Labor Market Participation. In Section 4.3, we look at the impact of female relative income on her participation in the labor market. We estimate the likelihood of withdrawing from the labor market in a one-year horizon $(\mathrm{T}+1)$. Consequently, the variable of interest is a dummy that codes 1 if the individual has no labor earnings in $\mathrm{T}+1$ (out of the labor market) and 0 otherwise.

Attitudinal Variables. We use subjective attitudes elicited in the SOEP survey, namely: How important is success at work for satisfaction? How important is marriage for satisfaction? How important is work for satisfaction? How important is a successful career for satisfaction? How important is family for your satisfaction? The first two questions were asked in 1992, 1995, 2004, 2008 and 2012. The remaining three questions were asked in 1991, 1994, 1998 and 1999. Given the distribution of preferences (see Figure F1 to Figure F5 in the Appendix), we define dummy variables that equal 1 if the respondent has declared the matter to be very important and 0 otherwise. 


\subsection{Descriptive Statistics}

Figure 2 depicts the entire distribution of female relative income in dual-earner married couples, aged 18 to 65 years old according to where they lived during the division (East or West Germany). The distribution is extremely skewed to the left in the sample of West German couples, where the mode is the point where the wife earns about 20\% of the total family earnings. By contrast, in the East German sample, the distribution is much more symmetric, with a mode around equal earnings. ${ }^{8}$ Nevertheless, in both regions, there are significantly fewer couples in a situation where the wife earns more than her husband than the opposite and the two distributions seem very similar beyond the point where the wife earns about $70 \%$ of the total income.

Figure 2: Female Income Share among Western and Eastern German Couples
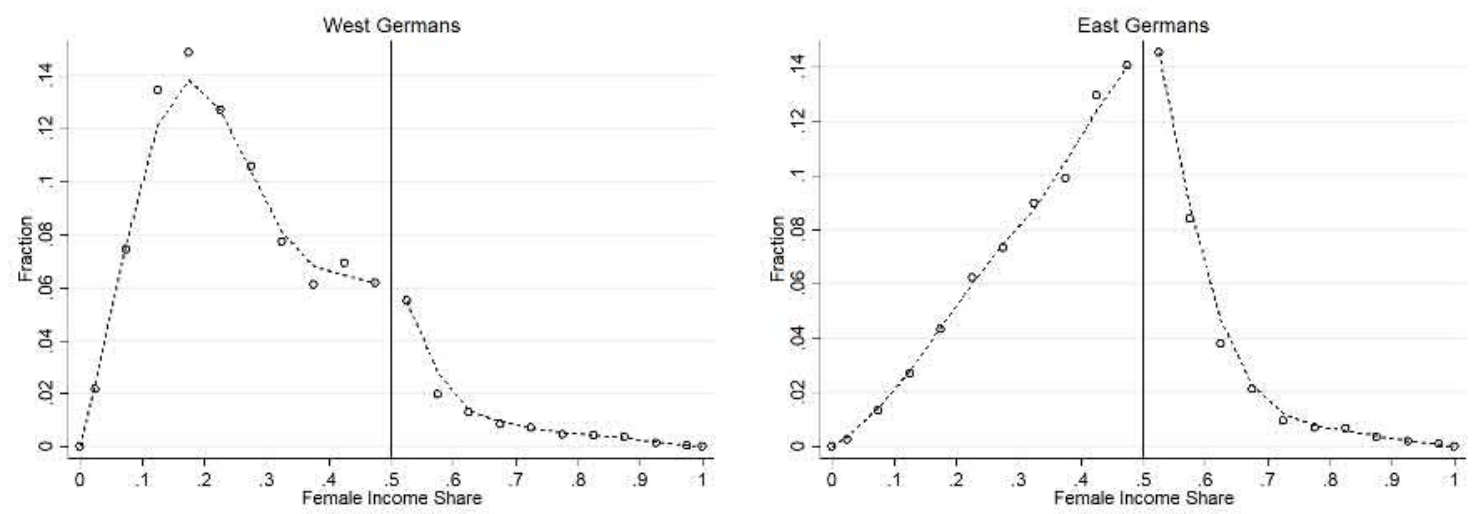

Notes: The data comes from the German Socio-Economic Panel using all the waves from 1991 until 2012. Sample: dual-earner married couples between 18 and 65 years of age. Female Income Share is defined as Female Income/(Female Income + Male Income). The vertical black line corresponds to Female Income Share $=0.5$. Each dot represents the fraction of couples in a 0.05 relative income bin. Eastern (Western) couples are those in which both spouses lived in GDR (FRG) before 1989.

Table 2 presents descriptive statistics on our main sample, using housework hours as the outcome. There are 6,104 couples for whom we know whether both members lived in East or West Germany before reunification: 1,976 are from East Germany and 4,129 from West Germany. On average, these couples are present in the sample for 5.6 years, which makes a total of 34,205 observations over 22 years (22,091 from West Germany

\footnotetext{
${ }^{8}$ Additionally, Figure $\mathrm{C} 1$ shows that these patterns display a slight convergence across cohorts and Figure C2 describes the limited evolution over time.
} 
and 12,114 from East Germany).

Table 2: Descriptive Statistics of the East/West Samples

\begin{tabular}{lcccccccc}
\hline & \multicolumn{3}{c}{ West Germans } & \multicolumn{5}{c}{ East Germans } \\
\hline & Mean & S.D. & Min & Max & Mean & S.D. & Min & Max \\
\hline Relative Income & 0.29 & 0.17 & 0 & 1 & 0.42 & 0.15 & 0 & 1 \\
WifeEarnsMore & 0.11 & 0.31 & 0 & 1 & 0.29 & 0.45 & 0 & 1 \\
Woman's Housework Time & 2.61 & 1.50 & 0 & 20 & 1.98 & 1.09 & 0 & 12 \\
Man's Housework Time & 0.61 & 0.72 & 0 & 16 & 0.68 & 0.73 & 0 & 10 \\
Hswk Woman - Hswk Man & 1.99 & 1.73 & -15 & 19 & 1.30 & 1.32 & -9 & 12 \\
Paid Work Time Woman & 27.03 & 13.29 & 1 & 80 & 37.72 & 10.40 & 1 & 80 \\
Paid Work Time Man & 44.60 & 9.81 & 1 & 80 & 45.70 & 9.77 & 1 & 80 \\
Income HH (Euros) & 3679.14 & 2405.09 & 10 & 200000 & 2660.94 & 1234.34 & 102 & 16259 \\
Income Woman (Euros) & 973.45 & 835.55 & 2 & 30170 & 1056.71 & 640.34 & 17 & 15000 \\
Income Man (Euros) & 2456.87 & 1703.53 & 46 & 99999 & 1477.82 & 913.59 & 25 & 15000 \\
Hourly Wage Woman & 8.62 & 5.43 & 0 & 129 & 6.79 & 4.11 & 0 & 96 \\
Hourly Wage Man & 13.14 & 8.62 & 0 & 392 & 7.84 & 4.99 & 0 & 138 \\
Woman's Age & 43.64 & 8.46 & 20 & 65 & 42.90 & 8.49 & 19 & 65 \\
Man's Age & 46.26 & 8.73 & 22 & 65 & 45.23 & 8.68 & 21 & 65 \\
Kids in HH (1=YES) & 0.68 & 0.47 & 0 & 1 & 0.72 & 0.45 & 0 & 1 \\
Observations & 22091 & & & & 12114 & & & \\
\hline
\end{tabular}

Notes: The data comes from the German Socio-Economic Panel using all the waves from 1991 until 2012. Descriptive statistics are based on the main sample: married couples with positive income. Eastern (Western) couples are those in which both spouses lived in GDR (FRG) before 1989. Income measures are based on 2010 constant euros. Number of housework or paid-work hours per day.

Households differ in several dimensions across the two samples. On average, West German households are richer, and more often childless. Men's level of income and contribution to household finance is higher in Western couples than in Eastern ones. ${ }^{9}$ The opposite holds for women. There are more Eastern couples where women earn more than their spouse (29\% versus $11 \%$ for Western couples). East German men spend a

\footnotetext{
${ }^{9}$ Note that household income includes all elements of income, including transfers and return on financial assets, whereas we use net labor income to construct our measure of women's relative contribution to household finance.
} 
slightly higher number of hours in housework than West German men, and the reverse is true for women.

In the West, we observe 698 transitions to a situation where the wife earns more and 513 in the opposite direction. These numbers are respectively 719 and 602 in the East. There are 16,208 observations where the wife always earns less than her husband in the West (resp. 6,190 in the East) and 1,423 where the wife earns more in all periods (resp. 2,316 in the East).

In the Appendix, Tables $\mathrm{C} 1$ and $\mathrm{C} 2$, we present descriptive statistics of the sample for the study of divorce and labor market participation. These samples are very similar to that described in Table 2. West German couples exhibit a higher divorce rate (within a 5-year horizon) than East German ones (9\% versus 7\%). Additionally, West German women withdraw more often from the labor market than East German ones $(2 \%$ versus $1 \%)$.

\section{Econometric Specification}

We use the German division as a natural experiment and argue that, absent this division, similar preferences would prevail in East and West Germany. In a sense, this setting is similar to a difference-in-differences strategy where we assume a similar starting point and a common trend assumption between the two regions. To illustrate the existence of the male breadwinner norm, we follow Bertrand et al. (2015) and focus on the specific point of equal incomes of spouses. ${ }^{10}$ Three outcomes are considered: the number of housework hours, the risk of divorce and labor market participation.

Formally, we estimate the following equation:

\footnotetext{
${ }^{10}$ Although this paper does not build on a structural model, we discuss in the Appendix Section A how our findings can be incorporated in the framework of a structural model of household behavior. In this framework, transgressing the male breadwinner norm produces a decrease in the value of the marriage which increases the risk of divorce or leads the wife to restore this value by shifting the division of tasks toward a more traditional arrangement.
} 


$$
Y_{i t}=\gamma_{1} \text { WifeEarnsMore }_{i t}+\gamma_{2} \text { WifeEarnsMore }_{i t} * \text { East }_{i}+\beta X_{i t}+\mu_{i}+\epsilon_{i t}
$$

Where $\mathrm{i}$ is the subscript for the individual and $\mathrm{t}$ for time. WifeEarnMore it $_{\text {it }}$ a dummy that equals 1 if the wife i earns more than her husband at time t. If the norm is prevalent among West Germans but not among East Germans, we expect $\gamma_{1}$ to be positive and significant, whereas $\gamma_{2}$ should be negative. If this norm does not exist among East Germans, $\gamma_{2}$ should totally offset $\gamma_{1}$.

The controls included in $X_{i t}$ are the log of household income, respondent and partner's age and age squared, respondent and partner's education level (4 categories), a dummy controlling for the presence of children, year fixed-effects and regional fixed-effects (at the Land level, 16 categories). Depending on the outcome considered, we also control for the degree of specialization within the couple, namely relative income, as this variable is likely to be correlated with the division of housework or the probability of withdrawing from the labor market. ${ }^{11}$

Our preferred specification contains individual fixed-effects $\mu_{i}$. This is important because it is likely that spouses match on unobserved characteristics, such as their preferences in terms of household income structure, which produces self-sorting of spouses into different types of families. For instance, without individual fixed-effects, the results could be driven by overachieving wives who earn more than their husbands and also spend more time on housework, or alternatively underachieving husbands with a strong preference for idleness. Introducing fixed-effects alleviates this selection issue.

One crucial assumption in this setting is the exogeneity of the treatment. If an individual could move from East to West Germany, or vice-versa, because of her preferences

\footnotetext{
${ }^{11}$ As pointed by Bertrand et al. (2015), controlling for relative income is important when standard Beckerian forces influence the outcome. In particular, they will lead the wife to do less housework when her relative income increases. For instance, couples where the wife earns $10 \%$ of the household income are probably couples where the wife has specialized in unpaid work activities. She is thus mechanically more likely to perform housework than a woman earning $40 \%$ of household income.
} 
for some gender-relevant aspect of institutions, this would bias our analysis. To overcome this issue, as explained in section 2.2, we define an East dummy variable that takes the value 1 if both spouses lived in GDR before reunification, independently of where they live at the time of the survey. Given that migration between the two regions was forbidden during the division and that there were no stark differences between East and West Germany before the division, exposure to the institutions can be considered as random. ${ }^{12}$

Unlike Bertrand et al. (2015), we do not test for the existence of a discontinuity in the distribution of household income. This is because, in our dataset, the number of observations at the point of equal earnings is too high, and is higher in the East $(2.75 \%)$ than in the West (1.37\%). This makes it impossible to run a McCrary test for the discontinuity of the distribution function at the point of equal earnings. ${ }^{13}$ However, in order to test for the relevance of the point of equal income, we run a robustness exercise consisting in estimating all of our regression equations with alternative thresholds, i.e. alternative focal points, as explained in section 5.3.1. We establish that the only relevant threshold is that of equal earnings.

The sample used in our main specification contains dual-earner married couples, aged 18 to 65 years old. The reason for not including households with unemployed adults is that this situation is most likely transitory and might not be reflected by the division of housework between spouses. We do not include couples where one spouse is out of the labor force, as the contribution of the latter to household finance is in most cases nil, and the allocation of her time into paid-word versus housework is trivially skewed. Moreover, couples where the wife changes from being out of the labor force to earning more than her husband are likely to be atypical. We select married couples rather than all couples because the former are generally more "stable" than simply cohabiting couples. However, in order to alleviate concerns about selection biases, we replicate all of our results using

\footnotetext{
${ }^{12}$ In the Appendix, we replicate all our results with a geographical definition based on where households currently live. They remain essentially unchanged.

${ }^{13} \mathrm{We}$ attribute this to the approximation of self-declared income by respondents in the SOEP survey, but we have no means to correct these figures and we are reluctant to -artificially- simply drop these observations.
} 
a larger sample including non-married and one-earner couples (See Appendix).

\section{Results - Consequences of Violating the Male Bread- winner Norm}

We study whether there is a difference across Western versus Eastern German couples in terms of the consequences of a wife earning more than her husband. Our outcomes of interest are: housework hours, the risk of divorce and female participation in the labor market.

\subsection{Housework. Couples of the Former GDR are Not "Doing Gender"}

We start with non-parametric visual evidence about the supply of housework hours by women, according to whether the spouses lived in the former GDR or not. Figure 3 displays the number of female housework hours according to the contribution of female earnings to the total earnings of the couple.

The left-hand-side panel shows that among West German couples, women decrease their number of housework hours as their relative earnings rise, until they reach the vicinity of equal earning. Beyond that point, their number of housework hours stops decreasing and remains at about 2 hours per day. It even seems to increase again at about $75 \%$. By contrast, the right hand-side panel shows that East German women monotonically reduce the time they devote to housework as their relative contribution to household finances increases. One can suspect an inflection in the curve at the point where women earn more than $80 \%$ of the couple's income, but due to the small number of couples who are in this situation, it is not possible to draw more than one dot. 
Figure 3: Women's Housework Time Depending on their Share of Income
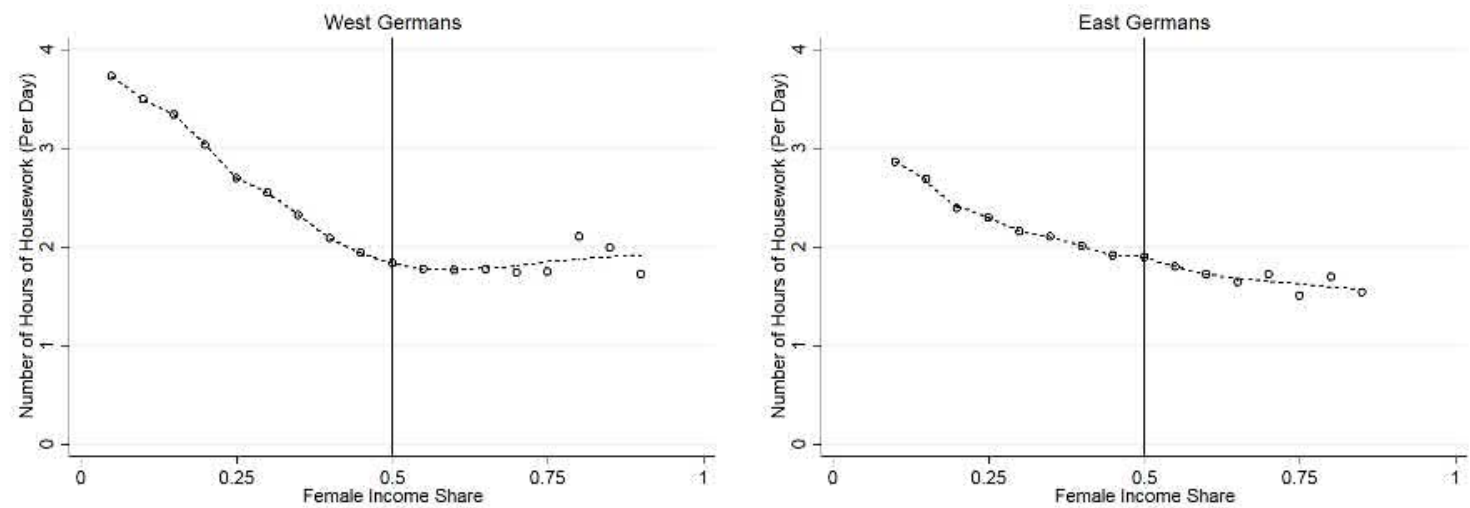

Notes: The data comes from the German Socio-Economic Panel using all the waves from 1991 until 2012. Sample: dual-earner married couples between 18 and 65 years of age. Female Income Share is defined as Female Income/(Female Income + Male Income). Each dot represents at least 50 observations in a 0.05 relative income bin (99.5\% of the total sample). The vertical black line corresponds to Female Income Share $=0.5$. Eastern (Western) couples are those in which both spouses lived in GDR (FRG) before 1989.

Figure 4 represents the relationship between men's housework time and their wives' relative income. Men monotonically increase their number of housework hours, with a small plateau around the point of equal incomes.

Figure 4: Male Housework Time Depending on Female's Share of Income
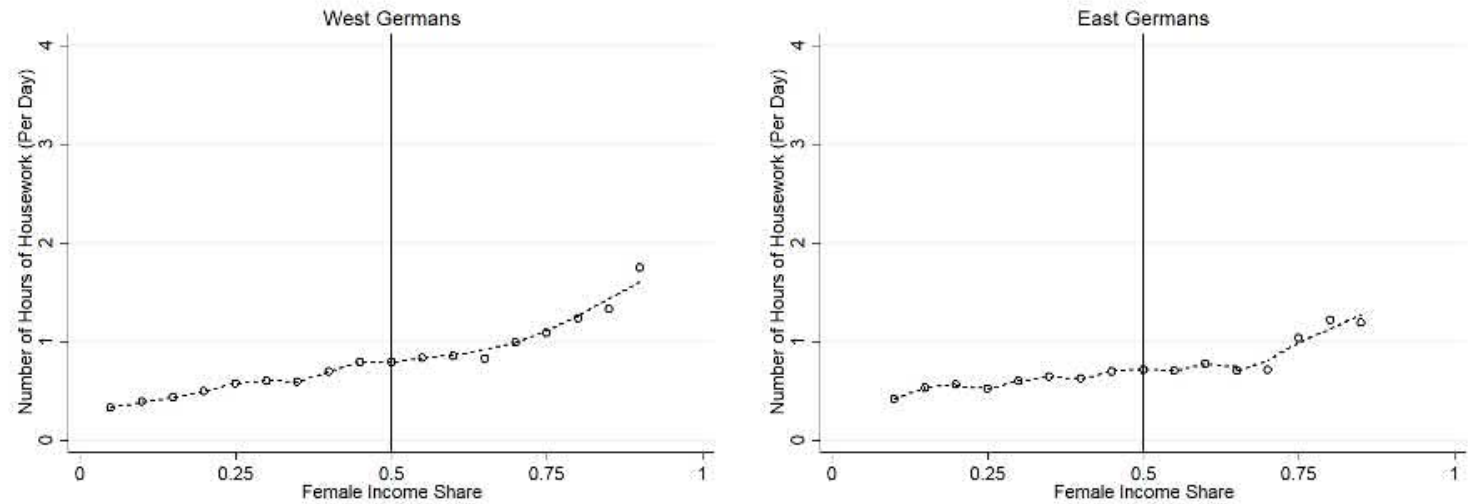

Notes: The data comes from the German Socio-Economic Panel using all the waves from 1991 until 2012. Sample: dual-earner married couples between 18 and 65 years of age. Female Income Share is defined as Female Income/(Female Income + Male Income). Each dot represents at least 50 observations in a 0.05 relative income bin (99.5\% of the total sample). The vertical black line corresponds to Female Income Share $=0.5$. Eastern (Western) couples are those in which both spouses lived in GDR (FRG) before 1989 .

Next, we estimate Equation 1 with and without individual fixed-effects using house- 
work hours as an outcome. Following Gupta (2007) who argues that individual income is a decisive determinant of the number of housework hours, as it reflects women's degree of autonomy, we augment the baseline specification and control for individual labor incomes (in the Appendix, we also test without controlling for individual incomes or introducing hourly wages). This is not totally collinear with household income as the latter includes non labor income.

The results are displayed in Table 3 . Columns 1 to 3 display cross-sectional OLS estimates and columns 4 to 6 estimations including individual fixed-effects. Panel $\mathrm{A}$ is restricted to the sample of women, panel B to their husbands and panel $\mathrm{C}$ studies the time gap between the spouses.

Columns 3 and 6 of panel A show that, as expected, the number of housework hours performed by West German women increases when they earn more than their husband. In column 6, we see that West German women increase their time spent on housework by about 0.18 hours per day when they start earning more than their husbands. This is not the case in East Germany. The interaction between the two variables, East and WifeEarnsMore is negative, and its order of magnitude is sufficient to offset exactly the positive coefficient of WifeEarnsMore, so that there is no effect left for East German couples. Accordingly, the coefficient on WifeEarnsMore is statistically significant when the regression is run on the subsample of West German women (in columns 1 and 4) but it is not when the subsample includes only East German women (columns 2 and 5). These results hold in cross-sectional as well as in fixed-effects specifications. Additionally, the East dummy variable (column 3) attracts a negative coefficient, indicating that East German women spend less time on housework than West German women. 
Table 3: Housework Time and Relative Income

\begin{tabular}{|c|c|c|c|c|c|c|}
\hline & $\begin{array}{l}\text { West } \\
(1)\end{array}$ & $\begin{array}{c}\text { East } \\
(2)\end{array}$ & $\begin{array}{l}\text { All } \\
(3)\end{array}$ & $\begin{array}{c}\text { West } \\
(4)\end{array}$ & $\begin{array}{c}\text { East } \\
(5)\end{array}$ & $\begin{array}{l}\text { All } \\
\text { (6) }\end{array}$ \\
\hline Panel A: Women & \multicolumn{6}{|c|}{ Dep Var: Housework Time (hours per day) } \\
\hline WifeEarnsMore & $\begin{array}{c}0.10^{* *} \\
(0.05)\end{array}$ & $\begin{array}{l}-0.02 \\
(0.04)\end{array}$ & $\begin{array}{c}0.12^{* *} \\
(0.05)\end{array}$ & $\begin{array}{c}0.17^{* * *} \\
(0.04)\end{array}$ & $\begin{array}{c}0.01 \\
(0.03)\end{array}$ & $\begin{array}{c}0.18^{* * *} \\
(0.04)\end{array}$ \\
\hline WifeEarnsMore*East & & & $\begin{array}{c}-0.14^{* *} \\
(0.06)\end{array}$ & & & $\begin{array}{c}-0.18^{* * *} \\
(0.05)\end{array}$ \\
\hline East & & & $\begin{array}{c}-0.67^{* * *} \\
(0.09)\end{array}$ & & & \\
\hline Observations & 22091 & 12114 & 34205 & 22091 & 12114 & 34205 \\
\hline Panel B: Men & \multicolumn{6}{|c|}{ Dep Var: Housework Time (hours per day) } \\
\hline WifeEarnsMore & $\begin{array}{c}-0.07^{* *} \\
(0.03)\end{array}$ & $\begin{array}{l}-0.04 \\
(0.03)\end{array}$ & $\begin{array}{c}-0.08^{* *} \\
(0.03)\end{array}$ & $\begin{array}{l}-0.04 \\
(0.03)\end{array}$ & $\begin{array}{l}-0.01 \\
(0.02)\end{array}$ & $\begin{array}{l}-0.04 \\
(0.03)\end{array}$ \\
\hline WifeEarnsMore*East & & & $\begin{array}{c}0.04 \\
(0.04)\end{array}$ & & & $\begin{array}{c}0.03 \\
(0.04)\end{array}$ \\
\hline East & & & $\begin{array}{c}0.17^{* * *} \\
(0.06)\end{array}$ & & & \\
\hline Observations & 22091 & 12114 & 34205 & 22091 & 12114 & 34205 \\
\hline Panel C: Couple & \multicolumn{6}{|c|}{ Dep Var: Housework Time Gap (Woman's - Man's) } \\
\hline WifeEarnsMore & $\begin{array}{c}0.17^{* * *} \\
(0.06)\end{array}$ & $\begin{array}{c}0.03 \\
(0.05)\end{array}$ & $\begin{array}{c}0.19^{* * *} * \\
(0.06)\end{array}$ & $\begin{array}{c}0.21^{* * *} \\
(0.05)\end{array}$ & $\begin{array}{c}0.02 \\
(0.04)\end{array}$ & $\begin{array}{c}0.23^{* * *} \\
(0.05)\end{array}$ \\
\hline WifeEarnsMore*East & & & $\begin{array}{c}-0.18^{* *} \\
(0.08)\end{array}$ & & & $\begin{array}{c}-0.21^{* * *} \\
(0.06)\end{array}$ \\
\hline East & & & $\begin{array}{c}-0.84^{* * *} \\
(0.11)\end{array}$ & & & \\
\hline Individual fixed-effects & No & No & No & Yes & Yes & Yes \\
\hline Individuals & 4128 & 1976 & 6104 & 4128 & 1976 & 6104 \\
\hline Observations & 22091 & 12114 & 34205 & 22091 & 12114 & 34205 \\
\hline
\end{tabular}

Notes: ${ }^{*} \mathrm{p}<0.1,{ }^{* *} \mathrm{p}<0.05,{ }^{* * *} \mathrm{p}<0.01$. The data comes from the German Socio-Economic Panel using all the waves from 1991 until 2012. The sample contains only dual earner married couples. Standard errors clustered at the individual level are given in parentheses. East is a dummy equals to 1 when both spouses lived in the former GDR before 1989. Controls: relative income between spouses, log of household income, respondent and partner's log of individual income, respondent and partner's age and age squared, respondent and partner's education level, a dummy controlling for the presence of children, year fixed-effects, Land fixed-effects and individual fixed-effects (columns 4,5 and 6).

Because doing gender is about within-couple interactions, it is of interest to observe 
the difference in the time spent on housework by each spouse. Panel C presents estimates of the time gap on the usual controls. Again, for West German couples, the time gap increases when the wife earns more than her husband all other things being equal (column 1 and 4), but this is not the case for East German couples (columns 2 and 5). Likewise, the coefficients on WifeEarnsMore and WifeEarnsMore * East totally compensate each other, so that no effect is left in East Germany (columns 3 and 6).

To probe the robustness of the results, we also replicate our results with a definition of housework that includes childcare (Table D1). Results are similar but the magnitude is much stronger when childcare is included. We also use the female share of total housework as the outcome variable instead of the time gap (Table D2). Results point in the same direction but are less precisely estimated.

\subsection{Marriage Instability}

Where gender norms are compelling, transgressing them should put one's marriage at risk. To enquire, we look at the association between women's relative income and marital instability.

Table 4 displays the probability of divorce within the next five years according to whether the wife earns more than her husband. ${ }^{14}$ The coefficient on WifeEarnsMore is positive and statistically significant in estimates that include individual fixed-effects (columns 4 and 6), but not in the cross-sectional estimates (column 1 to 3 ). Hence, it is a change in the situation of a couple that triggers divorce, rather than the difference between couples. This is consistent with the idea of self-selection of spouses into different types of couples.

Looking at column 4, we see that, among West German couples, when a wife starts earning more than her husband, the risk of divorce in the next 5 years increases by about 3 percentage points. Column 5 shows that nothing happens for East German couples

\footnotetext{
${ }^{14}$ It would be unrealistic to imagine that couples divorce immediately as soon as the wife starts earning more than her spouse. Accordingly, Table D7 displays the estimates of a linear probability model of the risk of divorce at different time-horizons.
} 
and consequently, when pooling both types of couples (column 6), the coefficient on WifeEarnsMore is offset by the one on WifeEarnsMore*East. This is consistent with the results concerning the number of housework hours.

Table 4: Risk of Divorce and Relative Income

\begin{tabular}{|c|c|c|c|c|c|c|}
\hline \multicolumn{7}{|c|}{ Dependent variable: Divorced within a 5-year time horizon $(1=Y e s)$} \\
\hline & $\begin{array}{c}\text { West } \\
(1)\end{array}$ & $\begin{array}{c}\text { East } \\
(2) \\
\end{array}$ & $\begin{array}{l}\text { All } \\
(3) \\
\end{array}$ & $\begin{array}{c}\text { West } \\
(4) \\
\end{array}$ & $\begin{array}{c}\text { East } \\
(5) \\
\end{array}$ & $\begin{array}{l}\text { All } \\
(6)\end{array}$ \\
\hline WifeEarnsMore & $\begin{array}{c}0.01 \\
(0.02)\end{array}$ & $\begin{array}{c}0.00 \\
(0.01)\end{array}$ & $\begin{array}{c}0.02 \\
(0.02)\end{array}$ & $\begin{array}{c}0.03^{* *} \\
(0.02)\end{array}$ & $\begin{array}{l}-0.01 \\
(0.01)\end{array}$ & $\begin{array}{c}0.03^{* *} \\
(0.02)\end{array}$ \\
\hline WifeEarnsMore*East & & & $\begin{array}{l}-0.01 \\
(0.02)\end{array}$ & & & $\begin{array}{c}-0.05^{* * *} \\
(0.02)\end{array}$ \\
\hline East & & & $\begin{array}{l}-0.01 \\
(0.03)\end{array}$ & & & \\
\hline Couple fixed-effects & No & No & No & Yes & Yes & Yes \\
\hline Couples & 1900 & 882 & 2782 & 1900 & 882 & 2782 \\
\hline Observations & 9054 & 4919 & 13973 & 9054 & 4919 & 13973 \\
\hline
\end{tabular}

Notes: $* \mathrm{p}<0.1,{ }^{* *} \mathrm{p}<0.05,{ }^{* * *} \mathrm{p}<0.01$. The data comes from the German SocioEconomic Panel using all the waves from 1991 until 2012. The dependent variable is a dummy that equals 1 if the couple has divorced within a 5 -year time horizon. The sample contains only dual earner married couples. Standard errors clustered at the couple level are given in parentheses. East is a dummy equals to 1 when both spouses lived in the former GDR before 1989. Controls: log of household income, man and woman's log of individual income, man and woman's age and age squared, man and woman's education level, a dummy controlling for the presence of children, year fixed-effects, Land fixed-effects and couple fixed-effects (columns 4,5 and 6).

\subsection{Labor Market Participation}

Bertrand et al. (2015) show that, in order to abide by the male breadwinner model, American women avoid earning more than their husband. This drives some of them, when their earning capacity is greater than that of their husband, to simply withdraw from the labor market. We ask whether this traditional behavior is also adopted by Eastern and Western German couples.

To do so, we estimate Equation 1 with and without fixed-effects, where the outcome variable is a dummy variable indicating whether an individual leaves the labor market 
within a year (in $\mathrm{T}+1)$. Table 5 displays the results. Columns 1 to 3 display crosssectional OLS estimates and columns 4 to 6 estimates that include individual fixed-effects. Panel A is restricted to the sample of women and panel B to their husbands.

Table 5: Labor Market Participation and Relative Income

\begin{tabular}{|c|c|c|c|c|c|c|}
\hline & $\begin{array}{c}\text { West } \\
(1) \\
\end{array}$ & $\begin{array}{c}\text { East } \\
(2) \\
\end{array}$ & $\begin{array}{l}\text { All } \\
(3) \\
\end{array}$ & $\begin{array}{c}\text { West } \\
(4) \\
\end{array}$ & $\begin{array}{c}\text { East } \\
(5) \\
\end{array}$ & $\begin{array}{l}\text { All } \\
(6) \\
\end{array}$ \\
\hline Panel A: Women & \multicolumn{6}{|c|}{ Dep. Var.: Out of the labor market in $T+1(1=Y e s)$} \\
\hline WifeEarnsMore & $\begin{array}{c}0.02 * * * \\
(0.00)\end{array}$ & $\begin{array}{c}0.00 \\
(0.00)\end{array}$ & $\begin{array}{c}0.02^{* * *} \\
(0.00)\end{array}$ & $\begin{array}{l}0.01^{*} \\
(0.00)\end{array}$ & $\begin{array}{l}-0.00 \\
(0.00)\end{array}$ & $\begin{array}{l}0.01^{*} \\
(0.00)\end{array}$ \\
\hline WifeEarnsMore*East & & & $\begin{array}{c}-0.02^{* * *} \\
(0.00)\end{array}$ & & & $\begin{array}{l}-0.01 \\
(0.01)\end{array}$ \\
\hline East & & & $\begin{array}{c}-0.03^{* * *} \\
(0.01)\end{array}$ & & & \\
\hline Individual fixed-effects & No & No & No & Yes & Yes & Yes \\
\hline Individuals & 3255 & 1510 & 4765 & 3255 & 1510 & 4765 \\
\hline Observations & 22159 & 12115 & 34274 & 22159 & 12115 & 34274 \\
\hline Panel B: Men & \multicolumn{6}{|c|}{ Dep. Var.: Out of the labor market in $T+1(1=Y e s)$} \\
\hline HusbandEarnsMore & $\begin{array}{c}-0.01^{* *} \\
(0.00)\end{array}$ & $\begin{array}{l}-0.00 \\
(0.00)\end{array}$ & $\begin{array}{c}-0.01^{*} \\
(0.00)\end{array}$ & $\begin{array}{l}-0.01^{*} \\
(0.00)\end{array}$ & $\begin{array}{l}-0.00 \\
(0.00)\end{array}$ & $\begin{array}{c}-0.01^{*} \\
(0.00)\end{array}$ \\
\hline HusbandEarnsMore*East & & & $\begin{array}{c}0.01 \\
(0.00)\end{array}$ & & & $\begin{array}{c}0.01 \\
(0.01)\end{array}$ \\
\hline East & & & $\begin{array}{c}-0.01^{*} \\
(0.01)\end{array}$ & & & \\
\hline Individual fixed-effects & No & No & No & Yes & Yes & Yes \\
\hline Individuals & 3255 & 1510 & 4765 & 3255 & 1510 & 4765 \\
\hline Observations & 22159 & 12115 & 34274 & 22159 & 12115 & 34274 \\
\hline
\end{tabular}

Notes: ${ }^{*} \mathrm{p}<0.1,{ }^{* *} \mathrm{p}<0.05,{ }^{* *} \mathrm{p}<0.01$. The data comes from the German Socio-Economic Panel using all the waves from 1991 until 2012. The sample is restricted to dual earner married couples in T. Standard errors clustered at the individual level are given in parentheses. The dependent variable is a dummy that equals 1 if the individual is not in the labor market in $\mathrm{T}+1$ (1 year horizon). East is a dummy equals to 1 when both spouses lived in the former GDR before 1989. Controls include relative income, log of household income, respondent and partners' age and age squared, respondent and partner's education level, a dummy controlling for the presence of children, year fixed-effects, Land fixed-effects and individual fixed-effects (columns 4,5 and 6).

The results are consistent with the previous outcomes. Columns 3 and 6 of panel A show that, as expected, the probability of a West German woman withdrawing from the 
labor market in $\mathrm{T}+1$ increases when she earns more than her husband. The interaction between the two variables, East and WifeEarnsMore is negative, and its order of magnitude is sufficient to offset exactly the positive coefficient of WifeEarnsMore, so that there is no effect left for East German couples. In column 6, although the coefficient related to WifeEarnsMore * East is not significant, it is close to standard significant levels (p-value of 0.129). Consistent with the previous outcomes, panel B shows that men do not withdraw from the labor market when their wife earns less than them. On the contrary, this situation reinforces the probability that they will remain in the labor market, especially in the West.

We now look at the labor market participation of women according to their potential income. We first predict individuals' potential income based on a Heckman selection model that includes a dummy variable for the presence of children in the selection equation. ${ }^{15}$ We then estimate potential wages for the entire sample of women based on the following characteristics: education (4 categories), age, age squared, year and Land fixed-effects. Next, we build a dummy that equals 1 if the potential wage of the individual is higher than the actual wage of his/her spouse (WifeEarnsMorePotentially and ManEarnsMorePotentially). About $21 \%$ of couples in our sample are in a situation where the potential earnings of the wife are higher than the actual earnings of her husband. ${ }^{16}$ Finally, we run a linear probability model in order to predict the likelihood of an individual participating in the labor market, according to the dummy WifeEarnsMorePotentially for the sample of women and ManEarnsMorePotentially for the sample of men. Since potential income can only change because of age, this specification does not include individual fixed-effects.

It turns out that when the potential wage of a woman is higher than the actual wage of her husband, the probability that she is out of the labor force increases by about 3 percentage points for West German women, whereas this pattern is reversed for East

\footnotetext{
${ }^{15}$ In the Appendix Table D8, we reproduce these estimates including a married dummy in the selection equation. We obtain similar results.

${ }^{16}$ In terms of actual incomes, $19 \%$ of couples in our sample are in that situation.
} 
German women (Table 6). When they earn potentially more than their husband, the probability of their withdrawal from the labor market diminishes by about 3 percentage points. Turning to the analysis of male behavior, we find a consistent pattern with the previous table. West German men are more likely to work when they earn potentially more than their wife, whereas East German men remain insensitive to this possibility.

Table 6: Labor Market Participation and Potential Relative Income

\begin{tabular}{|c|c|c|c|c|c|c|}
\hline & \multicolumn{3}{|c|}{$\begin{array}{c}\text { Women } \\
\text { Out of the labor force in } T\end{array}$} & \multicolumn{3}{|c|}{$\begin{array}{c}\text { Men } \\
\text { Out of the labor force in } T\end{array}$} \\
\hline & $\begin{array}{l}\text { West } \\
(1) \\
\end{array}$ & $\begin{array}{c}\text { East } \\
(2) \\
\end{array}$ & $\begin{array}{l}\text { All } \\
(3) \\
\end{array}$ & $\begin{array}{c}\text { West } \\
(4) \\
\end{array}$ & $\begin{array}{c}\text { East } \\
(5)\end{array}$ & $\begin{array}{c}\text { All } \\
(6) \\
\end{array}$ \\
\hline WifeEarnsMore Potentially & $\begin{array}{c}0.03^{* *} \\
(0.01)\end{array}$ & $\begin{array}{c}-0.03^{* * *} \\
(0.01)\end{array}$ & $\begin{array}{l}0.02^{*} \\
(0.01)\end{array}$ & & & \\
\hline WifeEarnsMore Potentially*East & & & $\begin{array}{c}-0.05^{* * *} \\
(0.02)\end{array}$ & & & \\
\hline ManEarnsMore Potentially & & & & $\begin{array}{c}-0.04^{* * *} \\
(0.02)\end{array}$ & $\begin{array}{l}-0.01 \\
(0.01)\end{array}$ & $\begin{array}{c}-0.04^{* * *} \\
(0.02)\end{array}$ \\
\hline ManEarnsMore Potentially*East & & & & & & $\begin{array}{c}0.04^{* *} \\
(0.02)\end{array}$ \\
\hline East & & & $\begin{array}{c}-0.14^{* *} \\
(0.05)\end{array}$ & & & $\begin{array}{c}-0.11^{* *} \\
(0.05)\end{array}$ \\
\hline Observations & 35848 & 14290 & 50138 & 32104 & 14647 & 43783 \\
\hline
\end{tabular}

Notes: ${ }^{*} \mathrm{p}<0.1,{ }^{* *} \mathrm{p}<0.05,{ }^{* * *} \mathrm{p}<0.01$. The data comes from the German Socio-Economic Panel using all the waves from 1991 until 2012. Standard errors clustered at the individual level are given in parentheses. East is a dummy equals to 1 when both spouses live in East Germany. Controls include log of husband income, log of household income, respondent and partners' age and age squared, respondent and partner's education level along with year fixed-effects and Land fixed-effects.

\section{Robustness Checks}

The norm of higher male earnings seems to be influential among West German couples, but not among former East German couples. All of the modalities of the typical doing gender behavior that have been documented in the literature seem to be at work among West German couples, i.e. higher female earnings are associated with longer housework hours, greater marriage instability and less participation in the labor market. This section 
tests the robustness of these results. We first test alternative samples and specifications. Then, we examine alternative mechanisms that could drive the results. Finally, we run several placebo tests for different focal points and other possible divisions of Germany.

\subsection{Alternative Samples and Specifications}

To ascertain our results, we run several robustness tests on the definition of the East dummy, the choice of the sample, specifications and period. The related Tables and Figures are in the Appendix.

First, we change the definition of the East dummy. The measure used previously required that both spouses lived in the former GDR or the former FRG before 1989. We now relax this assumption and show how the results vary depending on whether it is the wife or the husband who originates from either region. We find similar results using only the information about the husband or the wife (Table E3). We also consider the case of mixed-couples. Although it is not possible to perform similar regressions on this sample because of its limited size, we display descriptive statistics in Table E1 and show that they appear to behave in between purely Western and Eastern couples. Moreover, we replicate all of our main results using an alternative, purely geographic, definition of the East-West divide, i.e. classifying couples according to whether they currently live in a Land of the former GDR or of the former FRG at the time of the survey. Descriptive statistics are in Table E4 and the results are presented in Tables E5 and E6. They are similar to those obtained using the biographic definition (i.e. whether couples lived in East or West Germany before reunification).

Second, we run the same regressions on each of our three outcomes (housework hours, divorce and labor market participation) using alternative samples and specifications. We enlarge the sample to include single-earner couples and, alternatively, unmarried couples (Table E7): the results are identical. We also check the robustness of our results to the exclusion of outliers (Table E8). We use alternative specifications without controlling for individual incomes or household income, including quadratic terms in wages and 
introducing hourly wages (Table E9 for housework, Table E10 for divorce and Table E11 for labor market participation). The results remain essentially unchanged. We also use larger clusters to compute the standard errors. In our setting, part of the treatment is at the regional level but clustering at this level would lead to a number of clusters that is arguably too small (only two). We could also cluster at smaller geographical units but doing so would fail to capture the serial-correlation for households who moved across the territory. For this reason, we chose to cluster at the household level (which coincides with the individual level) in the main specification and repeat our main analysis with the relevant alternative options (district and Land level). The results do not change (see Tables E12 and E13 ).

Third, as market work and housework decisions can be made simultaneously, we check that our results are robust even for couples whose market work time does not vary. This is important, as it provides supporting evidence that our findings are not driven by a reallocation of time between paid-work and housework time, but instead by a variation in hourly wages. To do so, we replicate the main analysis related to housework and restrict the sample to couples whose female absolute and relative paid-work time remains constant or varies marginally. The results are displayed in Figure E1 and Figure E2. They show that the main results on housework remain similar. This supports an interpretation in terms of shock, where the variation in income is due to a change in hourly wages.

Finally, we drop the first years of reunification one by one, progressively, and re-run our analysis of female housework. This is because these years may have been experienced as exceptionally chaotic and uncertain, thus triggering certain behavior that is not generalizable. We display the results on housework as this is the outcome with the highest number of observations and statistical power. Table E14 shows that the results are unchanged even once these years have been dropped. 


\subsection{Alternative Mechanisms}

\subsubsection{Historical Differences in Unobservables: Evidence from the East/West Border}

We have established that the differences between the Eastern and Western parts of Germany were not larger than the average interregional differences in 1933, 1886 and 1849 but there may remain concerns about differences in unobservables characteristics related to gender norms. If there had been some regional differences before 1949, following an East-West axis, it is likely that the legacy of these historical differences in unobservables would be weaker in the vicinity of the East/West border. Therefore, we would expect more homogenous behavior as we move closer to the border.

To enquire, we exploit geolocated data and examine the behaviors of couples according to which side of the East/West border they currently live. For each household, we calculate the relative distance from its district to the East-West border. ${ }^{17}$ Figure 5 below displays the wife's contribution to household income at different points of space across the East-West border. We see that the wife's contribution to household finance is sharply discontinuous at the border, i.e. ten kilometers East and West from the former political border. More generally, the relative share of female income slightly increases as one moves from the Western part of Germany to the Eastern border, following parallel trends. This spatial discontinuity within an otherwise homogenous region is confirmed by the regressions displayed in Table E15. Even within a distance of 50 kilometers, the wife's share of income is 10 percentage points higher in couples who live at the East of the former border, than in couples who live on the West side (the difference is statistically significant at 1\%). This asymmetry in the structure of household income is not due to the fact that Eastern couples are poorer, hence need to rely more on female income. Indeed, the coefficient barely changes after controlling for household income in addition to spouses'

\footnotetext{
${ }^{17}$ The geographical unit refers to the so-called Kreis. This corresponds to a level of administration that is intermediate between the German States (Länder) and the municipalities. There are 404 districts in the database.
} 
age, age squared, a dummy controlling for the presence of children and education level (Model C of Table E15).

Figure 5: Female Share in Household Income Depending on the Distance to the East/West Border

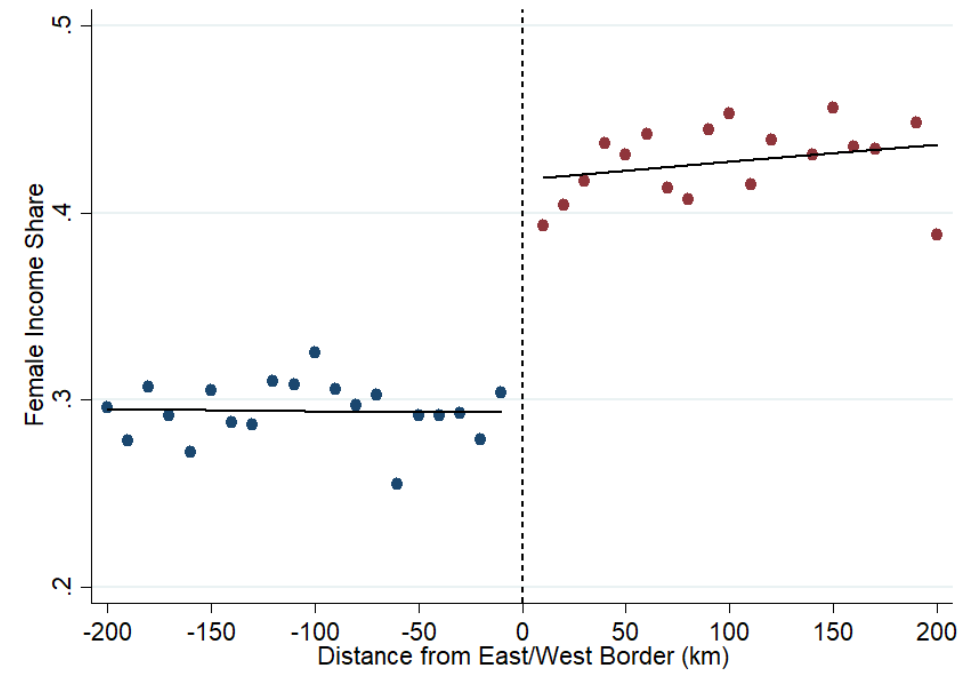

Notes: The data comes from the German Socio-Economic Panel using all the waves from 1991 until 2012. Sample: dual-earner married couples between 18 and 65 years of age without movers from East to West (or the opposite). The relative distance is defined as the euclidean distance in kilometers from the centroïd of the district to the East/West border. A positive (negative) distance means that the couple is geographically located in the East (West). The vertical dashed line corresponds to the border. Each dot represents the average value of the female income share in total household income, in a $10 \mathrm{~km}$ bin.

We also replicate the main results related to housework around the East/West border (we focus on housework because it is the most robust result and the least likely to be undermined by a smaller sample size). The results are available in Figure E3 and Table E16. Although the precision of the estimates is weaker closer to the border, we see that the coefficients remain essentially stable in magnitude across the territory, whereas historical and persisting differences in unobservables are expected to grow as we move away from the East/West border. This suggests that our findings are not driven by historical differences in unobservables but rather by the lasting consequences of the division of Germany. 


\subsubsection{Is the Difference Due to the Wage Structure?}

Although Eastern and Western Länder are now part of the same country, they still differ in several dimensions and in particular regarding the wage structure. We explore the role of three factors: lower household income, lower male hourly wage and lower wage dispersion in East Germany. These three factors could potentially explain our findings. For instance, in a context of low household income, individuals may not engage in doing gender behaviors because they simply cannot afford to divorce, to spend more time on housework or to withdraw from the labor market. Also, in a context of low male hourly wage, women could have a higher bargaining power within the household which could explain the absence of doing gender behaviors. Similarly, in a context of low dispersion of wages, the focal point of $50 \%$ could lose its meaningfulness.

To rule out these alternative explanations, we investigate the possible relationship between the wage structure and doing gender behaviors. We exploit the heterogeneity within West Germany (culturally homogeneous) and contrast the behavior of couples whose household income is high (similarly where male hourly wages and the dispersion of wages at the Land level are high) to couples whose household income is low (similarly where male hourly wages and the dispersion of wages at the Land level are low). Provided that there is sufficient heterogeneity within West Germany, this exercise will indicate whether our results may be due to these three confounding factors.

To quantify the level of heterogeneity, we use two types of measures. First, regional measures based on the average level of household income, male hourly wage and wage dispersion within a Land (macro definition). Second, individual measures based on the relative position of a household in West Germany in terms of household income and male hourly wages (micro definition). For each of these measures, we classify couples in two groups according to their position relative to the median value of the measure.

Descriptive statistics about the heterogeneity within West Germany are described in Table E17 for the household income level, Table E19 for the male hourly wage level and Table E21 for the dispersion of wages. Considering these three factors, we see that East 
German couples are often close to West German couples who stand below the median.

For each of these factors, we observe similar doing gender behaviors for households above or below the median. Women keep increasing their number of housework hours when they earn more than their husbands in West Germany, whether they are in a low or a high income household (Table E18). Similarly, the level of male hourly wages does not seem to alter the results (Table E20). Finally, measuring the dispersion of income using a Gini coefficient, we observe similar doing gender behaviors in Länder where the dispersion is below or above the West German median (Tables E22, E23, E24). This suggests that the East-West difference in household behavior is not due to the different structure of earnings in these regions.

\subsubsection{Other Institutional Differences}

Some of the East/West differences could be due to current objective structural disparities that might exist across German Länder. For example, unemployment is more pervasive in the East. It is also likely that the eastern part of Germany is still better equipped with childcare facilities than the western part, which could obviously influence women's work behavior. We extend the arguments developed in the previous section to focus on areas where Eastern and Western households live together.

The Case of Migrants. We first focus on Western Länder and contrast the behavior of West German "natives" to that of East German "immigrants" (i.e. those who lived in East Germany before 1990). In order to rule out the possibility that movers, as such, have idiosyncratic features that happen to be more gender-equal, we distinguish couples who always lived in the same Western Land (since they entered the survey) from those who moved from one Land to another within West Germany. Figure 6 displays the entire distribution of female relative income. In each of the three groups, the distribution has two hikes. Among non-mover Western couples, the principal mode is around 20\%, and we can see a minor one around $45 \%$ for "native" Western couples. But for former 
Eastern couples, the pattern is reversed. Finally, for movers from one Western Land to another, the two modes are approximately of equal importance. Hence, among couples who currently live in the West, those who immigrated from the East after 1990 still follow a much more gender-equal script. We also provide descriptive evidence in Table E25 about the characteristics of these couples. Considering the gender gap in housework hours and relative income, Eastern couples seem to be more gender equal than couples who have moved from one Western Land to another or than non-mover Western couples.

Figure 6: Distribution of Female Relative Income in Western Länder Depending on Couples' Former Location

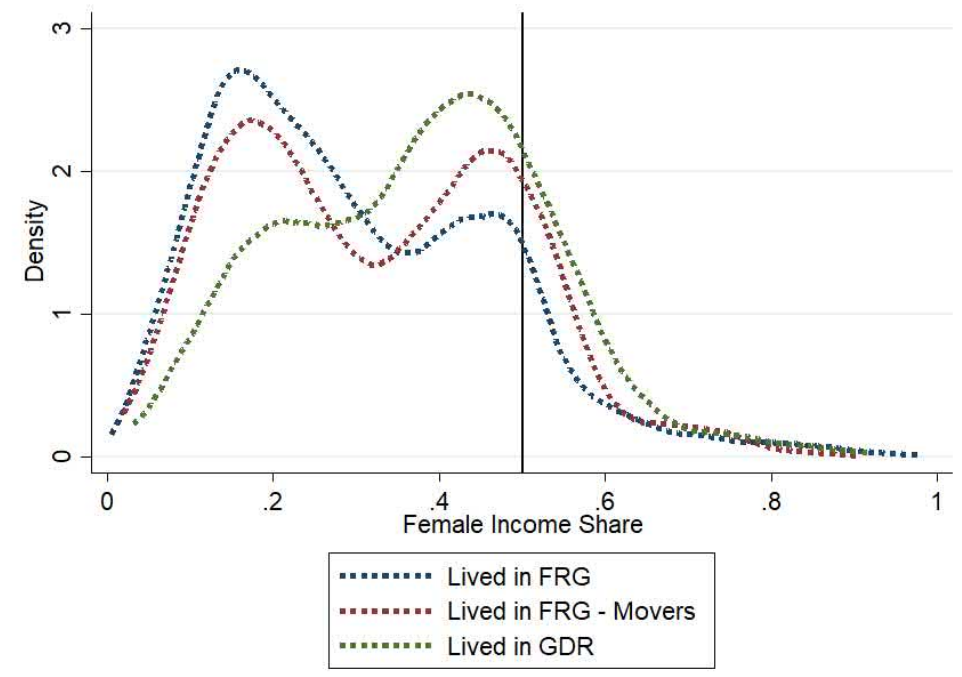

Notes: The data comes from the German Socio-Economic Panel using all the waves from 1991 until 2012. Sample: dual-earner married couples between 18 and 65 years of age living in Western Länder. Female Income Share is defined as Female Income/(Female Income + Male Income). The vertical black line corresponds to Female Income Share $=0.5$. Eastern (Western) couples are those in which both spouses lived in GDR (FRG) before 1989.

Focusing on Berlin. Finally, to rule out the possibility that persisting differences in the availability of childcare institutions explain the observed differences in terms of household behavior, we profit from a survey that was run in Berlin in 2011 (see Dolan et al., 2016). We use this additional database because it offers the unique feature of surveying a large sample of individuals located in a single city, with a distinction between dwellers in West Berlin and East Berlin. This gives us the possibility of observing people 
who live in a small, economically and spatially integrated and homogenous area. The survey asked respondents (all living in Berlin) where they used to live before 1990, and, if they were too young, where their mother used to live before 1990. People can choose between the following answers: East Berlin (within the former GDR), West Berlin (within the former FRG), GDR excluding Berlin, FRG excluding Berlin, other country part of the socialist bloc, or other country. The survey includes over 6,000 respondents, of whom 3,147 women, with 1,666 living in West Berlin and 1,481 living in East Berlin. We look at women's participation in the labor market, arguably the first outcome affected by the availability of childcare institutions, according to whether they (or their mother) lived in the FRG or the GDR during the division. Figure 7 displays the main results. It turns out that the effect of having lived in the East is of similar magnitude whether women currently live in East or West Berlin as of 2011: the proportion of women working part-time or fulltime is about 12 percentage points higher, i.e. approximately one third, among women who used to live in the East before 1990 as compared to women who used to live in the West. The results displayed in Figure 7 hold in Probit estimates that control for age, age squared and the presence of children under 16 in the household, and these differences hold only for women and not for men. Hence, even within a small geographic area, where childcare facilities are identically accessible to every household, the attachment to work is higher for women with an "East German" culture. In Figure E4, we also show that a similar pattern holds among young women. 
Figure 7: Female Participation in the Labor Market in Berlin
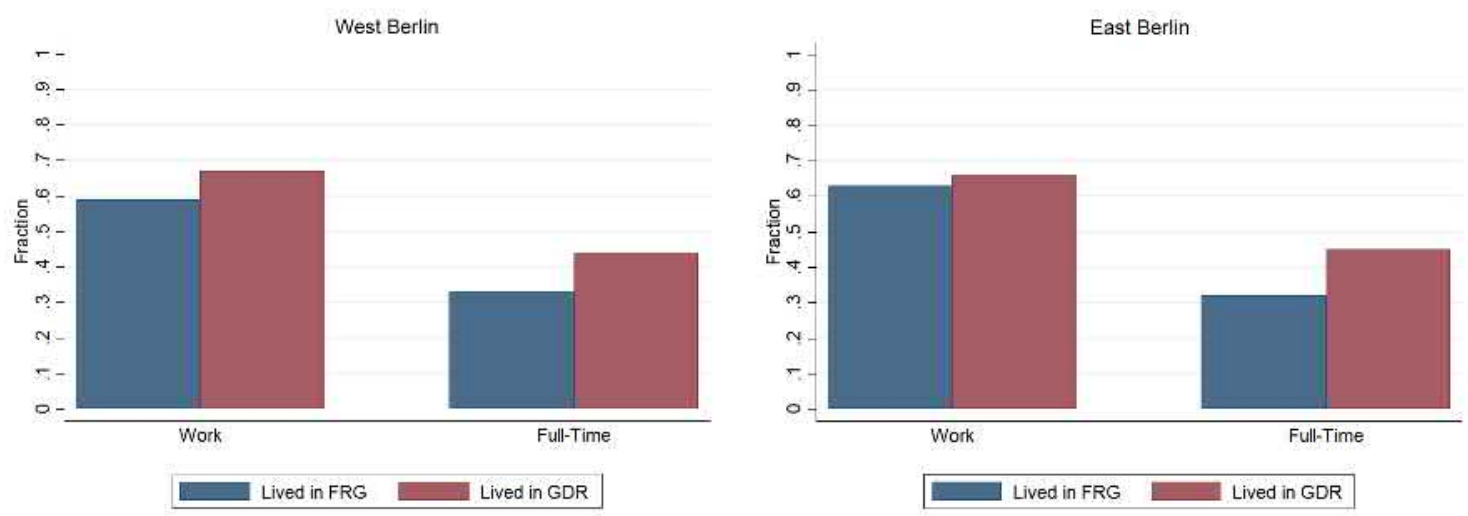

Notes: The left graph is restricted to women living in West Berlin. The graph on the right is restricted to women living in East Berlin.

\subsection{Placebo Tests}

\subsubsection{Other Possible Focal Points}

We have followed the literature in testing for the influence of the focal point of equal earnings between spouses. But could the threshold be lower or higher? To enquire, we run our preferred specification, following Equation 1, with respectively the number of female housework hours, the risk of divorce and the probability of being out of the labor force as independent variables, and we successively replace the dummy WifeEarns More by a dummy which equals 1 if the income of the wife is greater than $10 \%, 30 \%, 50 \%, 70 \%$ or $90 \%$, and 0 otherwise. The coefficient on the dummy variable starts being statistically significant only when the share of the wife's income reaches $50 \%$. This is true for the estimates of female housework hours (Table E27), marital instability (Table E28) and labor market participation (Table E29). The 50\% threshold is also the only point at which the results are significant for the three studied outcomes. Beyond this point, most of the coefficients turn statistically insignificant because many of the couples who are doing gender are on the other side of the cut-off point and because of the low number of observations. 


\subsubsection{Other Possible Divisions of Germany}

The paper's main claim is that the difference between East and West Germany stems from the different institutions that prevailed during the division. In order to challenge this interpretation, we run a systematic placebo exercise, which consists in testing the relevance of all of the possible divisions of the 15 German regions (excluding Berlin) into two groups of respectively 5 (Group 1) and 10 (Group 2) regions. This mimics the division of Germany into the GDR (5 Länder) and the FRG (10 Länder), excluding Berlin (by definition, this exercise uses a geographical definition of the East dummy variable). We run our preferred specification, following Equation 1 (with the number of female housework hours as the independent variable, as it provides the highest statistical power) and look at whether our coefficients of interest, i.e. those associated with the dummy WifeEarnsMore, and the interaction of WifeEarnsMore * Group1, are statistically significant, and at which level.

It turns out that out of 3,003 combinations, there are only 101 cases, i.e. 3.36\% cases, where both coefficients are statistically significant at the $1 \%$ level. Table E30 displays a synthetic analysis of the results, i.e. estimates of the probability that both coefficients of interest are statistically significant, according to the composition of Group 1 and Group 2, i.e. to how many Eastern Länder are included in Group 1. Column 1 displays the probability that the coefficients of interest are significant at the $10 \%$ level; column 2 at the $5 \%$ level and column 3 at the $1 \%$ level. The table shows that as more Eastern Länder are included in Group 1, the coefficients become more statistically significant. The difference between Eastern and Western Länder thus does not seem to be hiding another more relevant divide. 


\section{Direct Evidence on the East/West Divide in Gen- der Preferences}

We interpret the contrasted behavior of German couples, according to their origin, as the mark left by four decades of socialism on gender identity norms. In order to sustain this interpretation, we present some evidence of self-stated preferences and attitudes. This complements the information produced by Bauernschuster and Rainer (2012) and Beblo and Görges (2014), who used the German General Social Survey (ALLBUS). Table 7 presents the marginal effect of the following equation:

$$
\text { Preference }_{i t}=\gamma_{1} \text { East }_{i}+\gamma_{2} \text { Female }_{i}+\gamma_{3} \text { Female }_{i} * \text { East }_{i}+\beta X_{i t}+\epsilon_{i t}
$$

where the preferences of individual i in year $t$ depend on her gender and whether she has lived in East Germany or not before 1989, controlling for the usual socio-demographic variables (household income, age, age squared, presence of children in the household, education of both spouses, year and Land fixed-effects). 
Table 7: Attitudes to Work of East versus West Germans

\begin{tabular}{|c|c|c|c|c|c|}
\hline \multicolumn{6}{|c|}{ Dependent Variable: How Important is ... for your satisfaction? } \\
\hline & $\begin{array}{c}(1) \\
\text { Work }\end{array}$ & $\begin{array}{c}(2) \\
\text { Success } \\
\text { At Work }\end{array}$ & $\begin{array}{c}(3) \\
\text { A Successful } \\
\text { Career }\end{array}$ & $\begin{array}{c}(4) \\
\text { Marriage }\end{array}$ & $\begin{array}{c}(5) \\
\text { Family }\end{array}$ \\
\hline East & $\begin{array}{c}0.139 * * * \\
(0.019)\end{array}$ & $\begin{array}{c}0.028^{* * *} \\
(0.011)\end{array}$ & $\begin{array}{c}0.029^{*} \\
(0.016)\end{array}$ & $\begin{array}{c}0.008 \\
(0.011)\end{array}$ & $\begin{array}{c}0.012 \\
(0.011)\end{array}$ \\
\hline Female & $\begin{array}{c}-0.19 * * * \\
(0.015)\end{array}$ & $\begin{array}{c}-0.121^{* * *} \\
(0.008)\end{array}$ & $\begin{array}{c}-0.144^{* * *} \\
(0.014)\end{array}$ & $\begin{array}{c}0.037^{* * *} * \\
(0.008)\end{array}$ & $\begin{array}{c}0.032^{* * *} \\
(0.008)\end{array}$ \\
\hline Female*East & $\begin{array}{c}0.119^{* * *} \\
(0.02)\end{array}$ & $\begin{array}{c}0.098^{* * *} \\
(0.015)\end{array}$ & $\begin{array}{c}0.09^{* * *} \\
(0.019)\end{array}$ & $\begin{array}{l}-0.007 \\
(0.012)\end{array}$ & $\begin{array}{c}0.022^{* *} \\
(0.011)\end{array}$ \\
\hline Observations & 11147 & 20362 & 11098 & 20611 & 11271 \\
\hline
\end{tabular}

Notes: ${ }^{*} \mathrm{p}<0.1,{ }^{* *} \mathrm{p}<0.05,{ }^{* * *} \mathrm{p}<0.01$. Probit marginal effects. The data comes from the German Socio-Economic Panel using all the waves from 1991 until 2012. The sample contains only married couples. Standard errors clustered at the individual level are given in parentheses. East is a dummy equals to 1 when both spouses lived in the former GDR before 1989. Controls: log of household income, respondent and partner's age and age squared, respondent and partner's education level, a dummy controlling for the presence of children, a dummy representing whether the woman is working, a dummy representing whether the man is working and their interaction with the East dummy, year fixed-effects and Land fixed-effects.

As expected, column 1 of Table 7 shows that the probability of considering work as being important is 18.9 percentage points lower for a West German woman than for a West German man, but only 4.8 percentage points $(-0.189+0.141)$ lower for an East German woman than for an East German man. Other outcomes, such as the importance of success at work (column 2) and a successful career (column 3) follow the same pattern. For these three columns, the negative sign of $\gamma_{2}$ and the positive sign of $\gamma_{3}$ suggest that the gender gap in work-related preferences is narrower in East Germany than in West Germany.

One may wonder whether in East Germany, work values have crowded out family values, but this is not the case. Columns 4 and 5 respectively display estimates of the self-reported importance of marriage and family. The coefficients of interests are not statistically significant for column 4 and positive for column 5 , which suggests that there was no shift in preferences concerning marriage or family in East Germany. 
Additionally, in Figure F6 and Table F1, we investigate cohort patterns and find supporting evidence that the gender gap in preferences is particularly small among cohorts who lived in the GDR and were aged between 20 to 40 at the time of reunification. For older and younger cohorts, who were less exposed to socialist institutions, the gender gap seems closer to what is observed among West Germans.

\section{Conclusions}

During the four decades of the socialist episode in East Germany, institutions provided strong incentives for women's participation in the labor market, which, in turn, instilled more equal gender norms concerning the division of tasks between spouses. We show that these institutions created a culture that has undone the male breadwinner norm and its consequences. In particular, East German women can earn more than their husband without having to increase their number of housework hours, put their marriage at risk or withdraw from the labor market. By contrast the traditional norm of higher male earnings, and its consequences, are still prevalent in West Germany. These attitudes are mirrored by subjective preferences, as East German women attach almost as much value to paid work as men, contrarily to West German women.

We showed that these results are directly attributable to the cultural legacy created by the different institutions that prevailed during the division. To rule out alternative explanations, we first showed that the East-West differences did not preexist before the 1949 division, using first-hand statistical data pertaining to 1933, and exploiting Prussian data from the 19th century. We also provided evidence of the different behavior of women currently living in Berlin, according to which side of the iron curtain they used to live before reunification, and showed a similar pattern among East German couples who migrated to West Germany. Additionally, we replicated our results in a small geographical area surrounding the East/West border in order to rule out the role of historical differences in unobservables. We also analyzed the potential role of wage structure differentials and 
ran placebo exercises of alternative divides. Finally, we established that it is the focal point of equal incomes that triggers doing gender behaviors, as opposed to any other cut-off point.

Admittedly, this paper uses a reduced-form model in order to distinguish the cultural drivers of the East-West difference from other potential structural factors, such as local labor markets, marriage markets, income distribution, infrastructure, or other contextual features. The aforementioned robustness tests attempt to rule out the role of such alternative mechanisms. However, they do not measure the respective weight of these different factors. Future research using structural models of household behavior could fill that gap.

From a public policy perspective, one can wonder which of the many institutional differences that opposed the East and the West had the largest influence on gender norms. It would be difficult not to recognize that the root of the change was the full-time employment norm that became prevalent in the East during the Socialist era. This, in turn, was made possible by the work-family balance policy that was implemented in East Germany. In Western countries, the male breadwinner norm is likely to progressively vanish with the current extension of female education and labor market participation. How much time it will take is an open question but what this paper shows is that a large part of the answer is in the hands of policy-makers.

\author{
PARIS SCHOOL OF ECONOMICS \\ ORGANISATION FOR ECONOMIC CO-OPERATION AND DEVELOPMENT \\ PARIS SCHOOL OF ECONOMICS and SORBONNE UNIVERSITE
}




\section{References}

Akerlof, G.A. and Kranton, R.E. (2000). 'Economics and identity', The Quarterly Journal of Economics, vol. 115(3), pp. 715-753.

Akerlof, G.A. and Kranton, R.E. (2013). Identity economics: How our identities shape our work, wages, and well-being, Princeton University Press.

Alesina, A. and Fuchs-Schündeln, N. (2007). 'Good-bye lenin (or not?): The effect of communism on people's preferences', The American Economic Review, vol. 97(4), pp. $1507-1528$.

Alesina, A. and Giuliano, P. (2015). 'Culture and institutions', Journal of Economic Literature, vol. 53(4), pp. 898-944.

Alesina, A., Giuliano, P. and Nunn, N. (2013). 'On the origins of gender roles: Women and the plough', The Quarterly Journal of Economics, vol. 128(2), pp. 469-530.

Alessandra, F. and Laura, V. (2011). 'Nature or nurture? learning and the geography of female labor force participation', Econometrica, vol. 79(4), pp. 1103-1138.

Autor, D.H., Levy, F. and Murnane, R.J. (2003). 'The skill content of recent technological change: An empirical exploration', The Quarterly journal of economics, vol. 118(4), pp. 1279-1333.

Bauernschuster, S. and Rainer, H. (2012). 'Political regimes and the family: how sex-role attitudes continue to differ in reunified germany', Journal of Population Economics, vol. $25(1)$, pp. $5-27$.

Beaudry, P. and Lewis, E. (2014). 'Do male-female wage differentials reflect differences in the return to skill? cross-city evidence from 1980-2000', American Economic Journal: Applied Economics, vol. 6(2), pp. 178-194. 
Beblo, M. and Görges, L. (2014). 'Breaking down the wall between nature and nurture: An exploration of gendered work preferences in east and west germany', .

Becker, G.S. (1973). 'A theory of marriage: Part 1', Journal of Political economy, vol. 81(4), pp. 813-846.

Becker, G.S. (1974). 'A theory of marriage: Part 2', Journal of political Economy, vol. 82(2, Part 2), pp. S11-S26.

Becker, S., Cinnirella, F., Hornung, E. and Wöbmann, L. (2012). 'ipehd - the ifo prussian economic history database', .

Bertrand, M., Kamenica, E. and Pan, J. (2015). 'Gender identity and relative income within households', The Quarterly Journal of Economics, vol. 130(2), pp. 571-614.

Bisin, A. and Verdier, T. (2001). 'The economics of cultural transmission and the dynamics of preferences', Journal of Economic theory, vol. 97(2), pp. 298-319.

Bisin, A. and Verdier, T. (2011). 'Chapter 9 - the economics of cultural transmission and socialization', pp. 339 - 416, vol. 1 of Handbook of Social Economics, North-Holland.

Bittman, M., England, P., Sayer, L., Folbre, N. and Matheson, G. (2003). 'When does gender trump money? bargaining and time in household work', American Journal of sociology, vol. 109(1), pp. 186-214.

Black, S.E. and Spitz-Oener, A. (2010). 'Explaining women's success: technological change and the skill content of women's work', The Review of Economics and Statistics, vol. $92(1)$, pp. 187-194.

Blau, F.D. and Kahn, L.M. (2017). 'The Gender Wage Gap: Extent, Trends, and Explanations', Journal of Economic Literature, vol. 55(3), pp. 789-865.

Breen, R. and Cooke, L.P. (2005). 'The persistence of the gendered division of domestic labour', European Sociological Review, vol. 21(1), pp. 43-57. 
Campa, P. and Serafinelli, M. (2016). 'Politico-economic regimes and attitudes: Female workers under state-socialism', .

Charness, G. and Rabin, M. (2002). 'Understanding social preferences with simple tests', The Quarterly Journal of Economics, vol. 117(3), pp. 817-869.

Chiappori, P.A. (1988). 'Rational household labor supply', Econometrica, pp. 63-90.

Chiappori, P.A. (1992). 'Collective labor supply and welfare', Journal of political Economy, vol. 100(3), pp. 437-467.

Cooke, L.P. (2007). 'Persistent policy effects on the division of domestic tasks in reunified germany', Journal of Marriage and Family, vol. 69(4), pp. 930-950.

Cornelius, W.A. and Tsuda, T. (2004). 'Controlling immigration: The limits of government intervention', Controlling immigration: A global perspective, vol. 2, pp. 3-48.

Dolan, P., Kavetsos, G., Krekel, C., Mavridis, D., Metcalfe, R., Senik, C., Szymanski, S. and Ziebarth, N.R. (2016). 'The host with the most? the effects of the olympic games on happiness', .

Esping-Andersen, G. (2009). The incomplete revolution: Adapting welfare states to women's new role, Polity.

Evertsson, M. and Nermo, M. (2004). 'Dependence within families and the division of labor: Comparing sweden and the united states', Journal of Marriage and Family, vol. 66(5), pp. 1272-1286.

Fernández, R. (2013). 'Cultural change as learning: The evolution of female labor force participation over a century', The American Economic Review, vol. 103(1), pp. 472500.

Fernandez, R. and Fogli, A. (2009). 'Culture: An empirical investigation of beliefs, work, and fertility', American Economic Journal: Macroeconomics, vol. 1(1), pp. 146-177. 
Fernández, R., Fogli, A. and Olivetti, C. (2004). 'Mothers and sons: Preference formation and female labor force dynamics', The Quarterly Journal of Economics, vol. 119(4), pp. 1249-1299.

Goebel, J., Grabka, M.M., Liebig, S., Kroh, M., Richter, D., Schroder, C. and Schupp, J. (2018). 'The german socio-economic panel (soep)', Journal of Economics and Statistics.

Goldin, C. and Katz, L.F. (2002). 'The Power of the Pill: Oral Contraceptives and Women's Career and Marriage Decisions', Journal of Political Economy, vol. 110(4), pp. $730-770$.

Goldstein, J.R. and Kreyenfeld, M. (2011). 'Has east germany overtaken west germany? recent trends in order-specific fertility', Population and Development Review, vol. 37(3), pp. $453-472$.

Greenstein, T.N. (2000). 'Economic dependence, gender, and the division of labor in the home: A replication and extension', Journal of Marriage and Family, vol. 62(2), pp. $322-335$.

Gupta, S. (2007). 'Autonomy, dependence, or display? the relationship between married women's earnings and housework', Journal of Marriage and Family, vol. 69(2), pp. $399-417$.

Heckert, D.A., Nowak, T.C. and Snyder, K.A. (1998). 'The impact of husbands' and wives' relative earnings on marital disruption', Journal of Marriage and Family, pp. 690-703.

Jalovaara, M. (2003). 'The joint effects of marriage partners' socioeconomic positions on the risk of divorce', Demography, vol. 40(1), pp. 67-81.

Lippmann, Q. and Senik, C. (2018). 'Math, girls and socialism', Journal of Comparative Economics, vol. 46(3), pp. $874-888$. 
Liu, G. and Vikat, A. (2004). 'Does divorce risk depend on spouses' relative income? a register-based study of first marriages in sweden in 1981-1998', .

Rabin, M. (1993). 'Incorporating fairness into game theory and economics', The American economic review, vol. 83(5), pp. 1281-1302.

Rheinstein, M. and Glendon, M.A. (1978). 'West german marriage and family law reform', The University of Chicago Law Review, vol. 45(3), pp. 519-552.

Rosenfeld, R.A., Trappe, H. and Gornick, J.C. (2004). 'Gender and work in germany: Before and after reunification', Annu. Rev. Sociol., vol. 30, pp. 103-124.

Schenk, S. (2003). 'Employment opportunities and labour market exclusion: towards a new pattern of gender stratification', pp. 53-77, Reinventing Gender: Women in Eastern Germany Since Unification, Psychology Press.

Schneider, D. (2011). 'Market earnings and household work: New tests of gender performance theory', Journal of Marriage and Family, vol. 73(4), pp. 845-860.

Sullivan, O. (2010). 'Changing differences by educational attainment in fathers' domestic labour and child care', Sociology, vol. 44(4), pp. 716-733.

Weiss, Y. (1997). 'The formation and dissolution of families: Why marry? who marries whom? and what happens upon divorce', Handbook of population and family economics, vol. 1, pp. 81-123.

Weiss, Y. and Willis, R.J. (1997). 'Match quality, new information, and marital dissolution', Journal of Labor Economics, vol. 15(1), pp. 293-329.

West, C. and Zimmerman, D.H. (1987). 'Doing gender', Gender $\&$ society, vol. 1(2), pp. $125-151$. 


\section{Appendix}

\section{A How to Think about "Doing Gender" in the Framework of a Structural Model?}

Consider that couples (or husbands) have a preference for situations where the man earns more than his spouse $(\mathrm{Wf}<\mathrm{Wm}$, where $\mathrm{Wf}$ is the female wage and $\mathrm{Wm}$ the male wage). Respecting this norm creates a positive psychological value for the marriage (a positive contribution to welfare), by sustaining gender identity; conversely, violating the norm generates a negative value. This preference for gender identity, in turn, produces a certain type of "traditional" allocation of tasks within the household.

In this paper, we study the consequences of an increase in the relative wage of the wife that leads to a violation of the norm, i.e. to a situation where $\mathrm{Wf}>\mathrm{Wm}$. Let us first consider that the rise in the relative wage of the wife is due to a shock. We will then examine the case where this is the outcome of a decision.

Whether in a unitary or a collective model, the transgression of the norm may reduce the value of the marriage. In this case the wife can restore the degree of gender identity of the couple by accomplishing a greater share of housework, i.e. shifting the division of tasks toward a more traditional arrangement. In the case of a collective model à la Chiappori (1992), if the violation of the norm only hurts the husband, because spouses have different preferences, this may decrease the value of the marriage for the husband, hence reducing the bargaining power of the wife. In this case, the increase in the number of housework hours on behalf of the wife can be interpreted as a transfer of utility to the husband (due to a shift in distribution factors). Naturally, a shock that decreases the value of the marriage, in the eyes of the husband or both spouses, automatically increases the likelihood of divorce (Weiss and Willis, 1997). Finally, if a shock brings the wife's potential earnings higher than her husband's, and this is threatening the gender identity of the couple, hence the strength of the marriage, she (or they) might choose not to take the risk, hence to let the wife withdraw from the labor market. 
Now, in case the rise in the female relative income is not due to a shock, it is possible to rationalize our findings as the outcomes of a joint decision. First, the couple can "decide" ex ante to let the wage of the wife rise (by working more hours or accepting a wage rise or a promotion) as long as her number of housework increases too, in order to maintain the degree of gender intensity in the couple. They can also agree, ex ante, on the non-participation of the wife to the labor market, because of the potential violation of the norm that it would create and the associated loss of value for the marriage. Finally, spouses may also be shortsighted or may wrongly expect to be able to transfer utility, or to restore the gender identity of the couple, which leads them to take labor market decisions that fragilize their couple.

We interpret our results as the outcome of a shock. This is because our main findings are robust to the inclusion of individual fixed-effects and also because they are essentially unchanged when we restrict the sample to couples where female absolute and relative paid work-time remain constant or vary marginally. This supports an interpretation in terms of shock, where the variation in income is due to a change in hourly wages. 


\section{B Pre-Division Differences in the 19th Century}

Table B1 provides descriptive statistics on differences between East and West Germany in the 19th century. To compute this table, we have used Prussian data collected by Becker et al. (2012). We are able to replicate, to some extent, the same calculations as in Table 1 about the employment structure. Unfortunately, there is little data on gender differences except the share of girls enrolled in primary schooling. 
Table B1: East and West Germany in the 19th Century. Descriptive Statistics

\begin{tabular}{|c|c|c|c|c|c|}
\hline & $\begin{array}{l}\text { East } \\
(1) \\
\end{array}$ & $\begin{array}{c}\text { West } \\
(2) \\
\end{array}$ & $\mid$ East - West $\mid$ & $\begin{array}{c}\text { Average } \\
\text { Regional } \\
\text { Differences } \\
\quad(4) \\
\end{array}$ & P-value \\
\hline \multicolumn{6}{|l|}{ Panel A: 1882/1886 } \\
\hline Industry \% & 0.383 & 0.38 & 0.003 & $\begin{array}{c}0.04 \\
(0.03)\end{array}$ & 0.95 \\
\hline Agriculture \% & 0.497 & 0.484 & 0.013 & $\begin{array}{c}0.04 \\
(0.03)\end{array}$ & 0.82 \\
\hline Retail and Transport \% & 0.054 & 0.046 & 0.008 & $\begin{array}{c}0.006 \\
(0.004)\end{array}$ & 0.28 \\
\hline Services $\%$ & 0.08 & 0.078 & 0.002 & $\begin{array}{c}0.008 \\
(0.006)\end{array}$ & 0.89 \\
\hline Share of Girls in Primary School \% & 0.501 & 0.497 & 0.002 & $\begin{array}{c}0.002 \\
(0.002) \\
\end{array}$ & 0.11 \\
\hline \multicolumn{6}{|l|}{ Panel B: 1849} \\
\hline Industry \% & 0.114 & 0.138 & 0.024 & $\begin{array}{c}0.044 \\
(0.031)\end{array}$ & 0.67 \\
\hline Agriculture \% & 0.845 & 0.831 & 0.014 & $\begin{array}{c}0.046 \\
(0.033)\end{array}$ & 0.82 \\
\hline Services \% & .04 & .03 & .01 & $\begin{array}{l}0.007 \\
(0.004)\end{array}$ & 0.23 \\
\hline Share of Girls in Primary School \% & 0.492 & 0.488 & 0.004 & $\begin{array}{c}0.003 \\
(0.002)\end{array}$ & 0.32 \\
\hline
\end{tabular}

Notes: Own calculations based on Prussian data sets (collected by Becker et al., 2012). Panel A is restricted to data from 1882 and 1886. Panel B is restricted to data from 1849. We include only Prussian districts that will be part of FRG or GDR, excluding Berlin. The divide is based on German districts (Regierungsbezirk). In 1849, East: Erfurt, Frankfurt, Magdeburg, Merseburg, Potsdam, Stettin and Stralsund. West: Aachen, Arnsberg, Dusseldörf, Koblenz, Köln, Minden, Munster and Trier. In 1882/1886, additional data is available for the following Western districts: Aurich, Hannover, Hildesheim, Kassel, Lüneburg, Osnabruck, Schleswig, Sigmaringen, Stade and Wiesbaden. Column (4) displays the average absolute value of differences between regions in all possible regional partitions, as well as the standard error of these averages in parenthesis. Column (5) displays the probability that these differences are higher than the East/West difference displayed in column (3), which corresponds to the share of these differences that is higher than the East/West difference. 


\section{Additional Descriptive Statistics}

\section{C.1 Marriage Instability Sample}

Table C1: Descriptive Statistics of the East/West Samples for the Analysis of Divorce

\begin{tabular}{lcccccccc}
\hline & \multicolumn{3}{c}{ West Germany } & \multicolumn{5}{c}{ East Germany } \\
\hline & Mean & S.D. & Min & Max & Mean & S.D. & Min & Max \\
\hline Divorce at 5 Years & 0.09 & 0.29 & 0 & 1 & 0.07 & 0.25 & 0 & 1 \\
Relative Income & 0.28 & 0.16 & 0 & 1 & 0.43 & 0.14 & 0 & 1 \\
WifeEarnsMore (1=Yes) & 0.09 & 0.29 & 0 & 1 & 0.31 & 0.46 & 0 & 1 \\
Woman's Age & 42.17 & 7.27 & 21 & 63 & 41.47 & 7.24 & 21 & 60 \\
Man's Age & 44.75 & 7.51 & 22 & 63 & 43.69 & 7.39 & 23 & 61 \\
Household Income & 3514.32 & 1896.05 & 400 & 55000 & 2645.10 & 1123.42 & 460 & 16000 \\
Income Woman & 905.55 & 715.13 & 2 & 15000 & 1075.80 & 597.69 & 37 & 9715 \\
Income Man & 2379.90 & 1865.43 & 75 & 99999 & 1452.16 & 811.59 & 102 & 13000 \\
Kids in HH (1=Yes) & 0.74 & 0.44 & 0 & 1 & 0.81 & 0.39 & 0 & 1 \\
Observations & 9054 & & & & 4919 & & & \\
\hline
\end{tabular}

Notes: The data comes from the German Socio-Economic Panel using all the waves from 1991 until 2012. Descriptive statistics are based on the main sample: married couples with positive income. Eastern (Western) couples are those in which both spouses lived in GDR (FRG) before 1989. 


\section{C.2 Labor Market Participation Sample}

Table C2: Descriptive statistics of the East/West Samples for the Analysis of Labor Market Participation

\begin{tabular}{lcccccccc}
\hline & \multicolumn{3}{c}{ West Germany } & \multicolumn{5}{c}{ East Germany } \\
\hline \hline & Mean & S.D. & Min & Max & Mean & S.D. & Min & Max \\
\hline WomanOutLaborMarket T+1 & 0.02 & 0.14 & 0 & 1 & 0.01 & 0.08 & 0 & 1 \\
Woman's Share of Income & 0.28 & 0.16 & 0 & 1 & 0.42 & 0.15 & 0 & 1 \\
WifeEarnsMore & 0.10 & 0.30 & 0 & 1 & 0.29 & 0.45 & 0 & 1 \\
Paid Work Time Woman & 26.81 & 13.22 & 1 & 80 & 37.75 & 10.35 & 1 & 80 \\
Paid Work Time Man & 44.69 & 9.74 & 1 & 80 & 45.88 & 9.74 & 2 & 80 \\
Income HH (Euros) & 3680.29 & 2350.14 & 358 & 200000 & 2691.83 & 1215.62 & 409 & 16259 \\
Income Woman (Euros) & 970.00 & 831.21 & 2 & 30170 & 1067.38 & 626.38 & 17 & 15000 \\
Income Man (Euros) & 2462.87 & 1692.49 & 50 & 99999 & 1499.65 & 906.88 & 25 & 15000 \\
Hourly Wage Woman & 8.61 & 5.62 & 0 & 199 & 6.80 & 4.05 & 0 & 96 \\
Hourly Wage Man & 13.14 & 8.68 & 0 & 392 & 7.89 & 5.01 & 0 & 157 \\
Woman's Age & 43.55 & 8.39 & 20 & 65 & 42.94 & 8.41 & 19 & 65 \\
Man's Age & 46.17 & 8.67 & 22 & 65 & 45.27 & 8.60 & 21 & 65 \\
Kids in HH (1=YES) & 0.68 & 0.47 & 0 & 1 & 0.72 & 0.45 & 0 & 1 \\
Observations & 21047 & & & & 11560 & & & \\
\hline
\end{tabular}

Notes: The data comes from the German Socio-Economic Panel using all the waves from 1991 until 2012. Descriptive statistics are based on the main sample: married couples with positive income in $\mathrm{T}$ and information on $\mathrm{T}$ and $\mathrm{T}+1$. Eastern (Western) couples are those in which both spouses lived in GDR (FRG) before 1989. Number of housework or paid-work hours per day. 


\section{C.3 Relative Income in East and West Germany}

Figure C1: Female Income Share in West and East Germany per Cohort
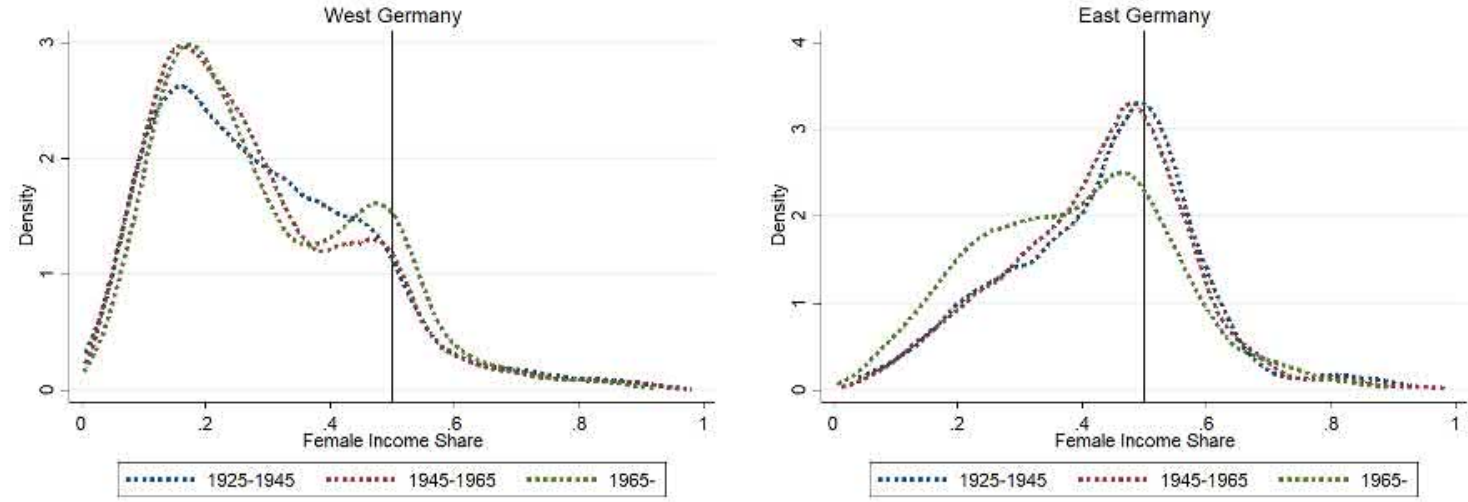

Notes: The data comes from the German Socio-Economic Panel using all the waves from 1991 until 2012. Generations are based on the year of birth. Sample: dual-earner married couples between 18 and 65 years of age. Female Income Share is defined as Female Income/(Female Income + Male Income). The vertical black line corresponds to Female Income Share $=0.5$. Eastern (Western) couples are those in which both spouses lived in GDR (FRG) before 1989. 
Figure C2: Female Income Share in West and East Germany in Different Years
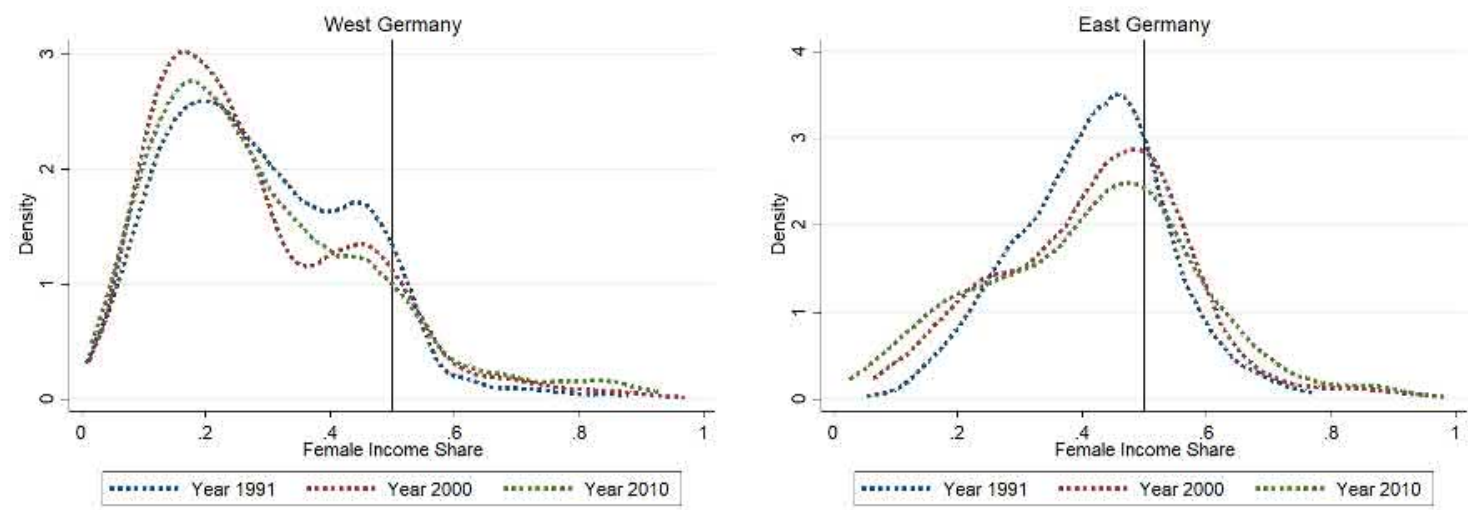

Notes: The data comes from the German Socio-Economic Panel waves in 1991, 2000 and 2010. Sample: dual-earner married couples between 18 and 65 years of age. Female Income Share is defined as Female Income/(Female Income + Male Income). The vertical black line corresponds to Female Income Share $=0.5$. Eastern (Western) couples are those in which both spouses lived in GDR (FRG) before 1989. 


\section{Additional Results}

\section{D.1 Housework - Adding Childcare}

Table D1: Woman's Housework+Childcare Time and Relative Income. Adding Childcare

\begin{tabular}{|c|c|c|c|c|c|c|}
\hline \multicolumn{7}{|c|}{ Dependent variable: Woman's Housework+Childcare Time (hours per day) } \\
\hline & $\begin{array}{l}\text { West } \\
(1)\end{array}$ & $\begin{array}{c}\text { East } \\
(2) \\
\end{array}$ & $\begin{array}{l}\text { All } \\
(3) \\
\end{array}$ & $\begin{array}{c}\text { West } \\
(4)\end{array}$ & $\begin{array}{c}\text { East } \\
(5) \\
\end{array}$ & $\begin{array}{l}\text { All } \\
(6) \\
\end{array}$ \\
\hline WifeEarnsMore & $\begin{array}{c}0.54^{* * *} \\
(0.16)\end{array}$ & $\begin{array}{c}0.12 \\
(0.11)\end{array}$ & $\begin{array}{c}0.64^{* * *} \\
(0.16)\end{array}$ & $\begin{array}{c}0.53^{* * *} \\
(0.14)\end{array}$ & $\begin{array}{c}0.18^{* *} \\
(0.08)\end{array}$ & $\begin{array}{c}0.62^{* * *} \\
(0.14)\end{array}$ \\
\hline WifeEarnsMore*East & & & $\begin{array}{c}-0.53^{* * *} \\
(0.19)\end{array}$ & & & $\begin{array}{c}-0.44^{* * *} \\
(0.16)\end{array}$ \\
\hline East & & & $\begin{array}{c}-2.08 * * * \\
(0.29)\end{array}$ & & & \\
\hline Individual fixed-effects & No & No & No & Yes & Yes & Yes \\
\hline Individuals & 4082 & 1958 & 6040 & 4082 & 1958 & 6040 \\
\hline Observations & 21292 & 11592 & 32884 & 21292 & 11592 & 32884 \\
\hline
\end{tabular}

Notes: ${ }^{*} \mathrm{p}<0.1,{ }^{*} \mathrm{p}<0.05,{ }^{* * *} \mathrm{p}<0.01$. The data comes from the German Socio-Economic Panel using all the waves from 1991 until 2012. The sample contains only dual earner couples. Standard errors clustered at the individual level are given in parentheses. East is a dummy equals to 1 when both spouses lived in the former GDR before 1989. Controls include relative income between spouses, log of household income, log of woman's income and log of man's income, respondent and partners' age and age squared, respondent and partner's education level, a dummy controlling for the presence of children, year fixed-effects, Land fixed-effects and individual fixed-effects (columns 4,5 and 6). 


\section{D.2 Housework - Analyzing the Share of Housework}

This section considers alternative outcome measures for housework. Although we could use the share of female housework instead of the time gap, we believe that the latter is more suited to an econometric analysis. We hereafter explain why.

In Figure D1, we plot the distribution of the female share of housework and of the time gap. We see that the distribution of the female share of housework is highly skewed towards 1 . This is because the time spent on housework is measured using the following question: "What is a typical weekday like for you? How many hours per normal workday do you spend on housework (washing, cooking, cleaning)?. Answers are given in the form of integers $0,1,2, \ldots$ and as such rounded to zero if the time is closer to zero than from 1 .

In Table D2, we display the results using the share of housework. Dependent variables are: for Panel A the share of female housework measured as a continuous variable, and for Panel B a dummy that equals 1 if the female share is equal to $100 \%$. The two panels deliver results that are similar to those obtained using the time gap measure, although they are less robust and less precisely estimated. In particular, columns 4 to 6 show that when a woman earns more than her husband, her share of housework time increases by about 2 p.p. in the West (column 4) but not in the East (column 5), but the interaction in column 6 is not statistically significant at conventional thresholds (the coefficient associated to WifeEarnsMore*East has a p-value equals to 0.105 in Panel A and to 0.185 in Panel B). Yet, these results are less precisely estimated, in part because of the skewness of the distribution of this new outcome.

Another potential factor explaining the results based on the time gap measure is the weight of outliers. Using the time gap necessarily gives more weight to the outliers, which could thus drive the results. To alleviate this concern, Table D3 runs the main specification excluding outliers. The results are robust to excluding progressively the top and bottom 1\% (column 1), 5\% (column 2) and 10\% (column 3).

Additionally, using the time gap could give more weight to households who spend a greater total number of housework hours because as this total increases, the time gap is likely to increase too. In Table D4, we replicate the main results controlling for the total number of housework hours. We see that the cross-sectional estimates are slightly less precise (column 1 to 3 ) but that the fixed-effects specifications remain essentially unchanged. 
Figure D1: Distribution of Housework Measures

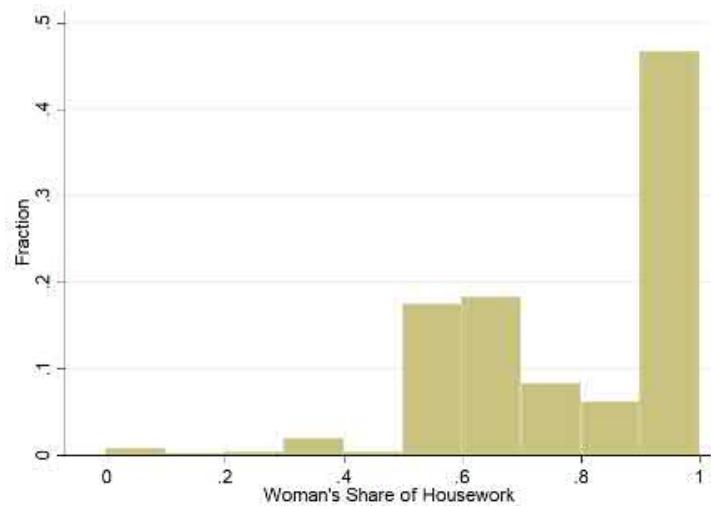

(a) Female Share of Housework

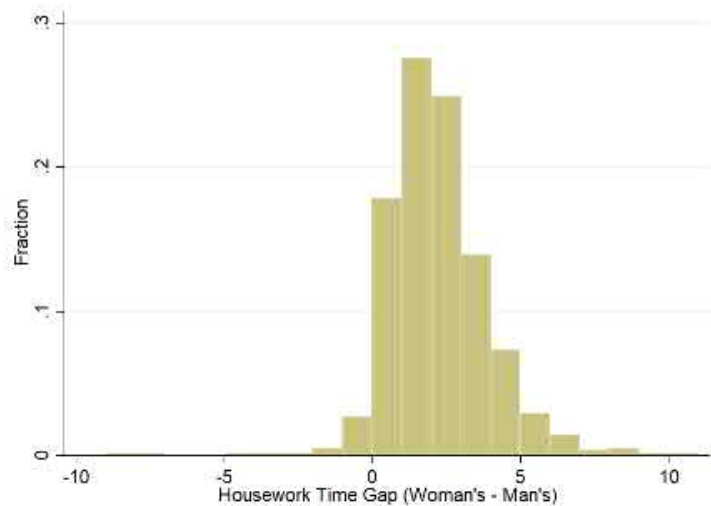

(b) Housework Time Gap

Notes: The data comes from the German Socio-Economic Panel using all the waves from 1991 until 2012. Sample: dual-earner married couples between 18 and 65 years of age. Figure (a) represents the distribution of the female share of housework (Female Housework Time/(Female+Male Housework Time)). Figure (b) represents the distribution of the housework time gap between spouses (Female Housework Time - Male Housework Time). 
Table D2: Housework Time and Relative Income. Analyzing the Share of Housework Time

\begin{tabular}{|c|c|c|c|c|c|c|}
\hline & $\begin{array}{l}\text { West } \\
(1)\end{array}$ & $\begin{array}{l}\text { East } \\
(2)\end{array}$ & $\begin{array}{l}\text { All } \\
(3)\end{array}$ & $\begin{array}{c}\text { West } \\
(4)\end{array}$ & $\begin{array}{c}\text { East } \\
(5)\end{array}$ & $\begin{array}{l}\text { All } \\
(6)\end{array}$ \\
\hline Panel A: Continuous Measure & \multicolumn{6}{|c|}{ Dep Var: Woman's Share of Housework } \\
\hline WifeEarnsMore & $\begin{array}{c}0.02 \\
(0.01)\end{array}$ & $\begin{array}{c}0.00 \\
(0.01)\end{array}$ & $\begin{array}{c}0.02 \\
(0.01)\end{array}$ & $\begin{array}{c}0.02 * * \\
(0.01)\end{array}$ & $\begin{array}{l}-0.00 \\
(0.01)\end{array}$ & $\begin{array}{c}0.02^{* *} \\
(0.01)\end{array}$ \\
\hline WifeEarnsMore*East & & & $\begin{array}{l}-0.01 \\
(0.01)\end{array}$ & & & $\begin{array}{l}-0.02 \\
(0.01)\end{array}$ \\
\hline East & & & $\begin{array}{c}-0.07^{* * *} \\
(0.02)\end{array}$ & & & \\
\hline Individual fixed-effects & No & No & No & Yes & Yes & Yes \\
\hline Individuals & 4132 & 1969 & 6101 & 4132 & 1969 & 6101 \\
\hline Observations & 21992 & 12024 & 34016 & 21992 & 12024 & 34016 \\
\hline Panel B: Dummy & \multicolumn{6}{|c|}{ Dep Var: Woman's Share of Housework $=100 \%(1=$ Yes $)$} \\
\hline WifeEarnsMore & $\begin{array}{c}0.02 \\
(0.01)\end{array}$ & $\begin{array}{c}0.00 \\
(0.01)\end{array}$ & $\begin{array}{c}0.02 \\
(0.01)\end{array}$ & $\begin{array}{c}0.02 * * \\
(0.01)\end{array}$ & $\begin{array}{l}-0.00 \\
(0.01)\end{array}$ & $\begin{array}{c}0.02^{* *} \\
(0.01)\end{array}$ \\
\hline WifeEarnsMore*East & & & $\begin{array}{l}-0.01 \\
(0.01)\end{array}$ & & & $\begin{array}{l}-0.02 \\
(0.01)\end{array}$ \\
\hline East & & & $\begin{array}{c}-0.07^{* * *} \\
(0.02)\end{array}$ & & & \\
\hline Individual fixed-effects & No & No & No & Yes & Yes & Yes \\
\hline Individuals & 4132 & 1969 & 6101 & 4132 & 1969 & 6101 \\
\hline Observations & 21992 & 12024 & 34016 & 21992 & 12024 & 34016 \\
\hline
\end{tabular}

Notes: ${ }^{*} \mathrm{p}<0.1,{ }^{* *} \mathrm{p}<0.05,{ }^{* * *} \mathrm{p}<0.01$. The data comes from the German Socio-Economic Panel using all the waves from 1991 until 2012. The sample contains only dual earner married couples. Standard errors clustered at the individual level are given in parentheses. East is a dummy equals to 1 when both spouses lived in the former GDR before 1989. Controls: relative income between spouses, log of household income, respondent and partner's log of individual income, respondent and partner's age and age squared, respondent and partner's education level, a dummy controlling for the presence of children, year fixed-effects, Land fixed-effects and individual fixed-effects (columns 4,5 and 6). 
Table D3: Housework Time and Relative Income. Removing Outliers

\begin{tabular}{lccc}
\hline Dep Var: Housework Time Gap & (Woman's - Man's) \\
\hline \hline WifeEarnsMore & $(1)$ & $(2)$ & $(3)$ \\
& $0.21^{* * *}$ & $0.17^{* * *}$ & $0.16^{* * *}$ \\
& $(0.05)$ & $(0.05)$ & $(0.05)$ \\
WifeEarnsMore*East & $-0.20^{* * *}$ & $-0.15^{* *}$ & $-0.11^{*}$ \\
& $(0.06)$ & $(0.06)$ & $(0.06)$ \\
Sample Restriction & $1 \%$ & $5 \%$ & $10 \%$ \\
Individual fixed-effects & Yes & Yes & Yes \\
Individuals & 6020 & 5537 & 5464 \\
Observations & 32680 & 26123 & 25131 \\
\hline
\end{tabular}

Notes: $* \mathrm{p}<0.1,{ }^{* *} \mathrm{p}<0.05,{ }^{* * *} \mathrm{p}<0.01$. The data comes from the German Socio-Economic Panel using all the waves from 1991 until 2012. The sample contains only dual earner married couples. Standard errors clustered at the individual level are given in parentheses. East is a dummy equals to 1 when both spouses lived in the former GDR before 1989 . Controls: relative income between spouses, $\log$ of household income, respondent and partner's log of individual income, respondent and partner's age and age squared, respondent and partner's education level, a dummy controlling for the presence of children, year fixed-effects, Land fixed-effects and individual fixed-effects (columns 4,5 and 6). 
Table D4: Housework Time and Relative Income. Controlling for Total Housework Hours.

\begin{tabular}{lcccccc}
\hline \multicolumn{6}{c}{ Dep Var: Housework Time Gap (Woman's - Man's) } \\
\hline & $\begin{array}{c}\text { West } \\
(1)\end{array}$ & $\begin{array}{c}\text { East } \\
(2)\end{array}$ & $\begin{array}{c}\text { All } \\
(3)\end{array}$ & $\begin{array}{c}\text { West } \\
(4)\end{array}$ & $\begin{array}{c}\text { East } \\
(5)\end{array}$ & $\begin{array}{c}\text { All } \\
(6)\end{array}$ \\
\hline \hline WifeEarnsMore & $0.16^{* * *}$ & 0.05 & $0.17^{* * *}$ & $0.15^{* * *}$ & 0.02 & $0.16^{* * *}$ \\
& $(0.06)$ & $(0.05)$ & $(0.06)$ & $(0.05)$ & $(0.04)$ & $(0.05)$ \\
WifeEarnsMore*East & & & $-0.13^{*}$ & & & $-0.14^{* *}$ \\
& & & $(0.07)$ & & & $(0.06)$ \\
East & & & $-0.60^{* * *}$ & & & \\
& & & $(0.10)$ & & & \\
Total Household Housework Hours & $0.55^{* * *}$ & $0.31^{* * *}$ & $0.48^{* * *}$ & $0.51^{* * *}$ & $0.27^{* * *}$ & $0.44^{* * *}$ \\
& $(0.02)$ & $(0.02)$ & $(0.01)$ & $(0.02)$ & $(0.02)$ & $(0.02)$ \\
Individual fixed-effects & No & No & No & Yes & Yes & Yes \\
Individuals & 4128 & 1976 & 6104 & 4128 & 1976 & 6104 \\
Observations & 22091 & 12114 & 34205 & 22091 & 12114 & 34205 \\
\hline
\end{tabular}

Notes: ${ }^{*} \mathrm{p}<0.1,{ }^{*} \mathrm{p}<0.05, * * * \mathrm{p}<0.01$. The data comes from the German Socio-Economic Panel using all the waves from 1991 until 2012. The sample contains only dual earner married couples. Standard errors clustered at the individual level are given in parentheses. East is a dummy equals to 1 when both spouses lived in the former GDR before 1989. Controls: relative income between spouses, log of household income, total housework hours, respondent and partner's log of individual income, respondent and partner's age and age squared, respondent and partner's education level, a dummy controlling for the presence of children, year fixed-effects, Land fixed-effects and individual fixed-effects (columns 4,5 and 6). 
D.3 Housework - Controlling for Paid Work Time 
Table D5: Housework Time and Relative Income - Controlling for PaidWork Time and Including Log Individual Incomes

\begin{tabular}{|c|c|c|c|c|c|c|}
\hline \multicolumn{7}{|c|}{ Dependent variable: Woman's Housework Time (hours per day) } \\
\hline & $\begin{array}{l}\text { West } \\
(1)\end{array}$ & $\begin{array}{c}\text { East } \\
(2)\end{array}$ & $\begin{array}{l}\text { All } \\
(3)\end{array}$ & $\begin{array}{c}\text { West } \\
(4)\end{array}$ & $\begin{array}{c}\text { East } \\
(5)\end{array}$ & $\begin{array}{l}\text { All } \\
(6)\end{array}$ \\
\hline Panel A: Women & \multicolumn{6}{|c|}{ Dep Var: Housework Time (hours per day) } \\
\hline WifeEarnsMore & $\begin{array}{c}0.03 \\
(0.05)\end{array}$ & $\begin{array}{l}-0.05 \\
(0.04)\end{array}$ & $\begin{array}{c}0.05 \\
(0.05)\end{array}$ & $\begin{array}{c}0.13^{* * *} \\
(0.04)\end{array}$ & $\begin{array}{l}-0.01 \\
(0.03)\end{array}$ & $\begin{array}{c}0.15^{* * *} \\
(0.04)\end{array}$ \\
\hline WifeEarnsMore*East & & & $\begin{array}{l}-0.11^{*} \\
(0.06)\end{array}$ & & & $\begin{array}{c}-0.18^{* * *} \\
(0.05)\end{array}$ \\
\hline East & & & $\begin{array}{c}-0.47^{* * *} \\
(0.10)\end{array}$ & & & \\
\hline Observations & 20836 & 11469 & 32305 & 20836 & 11469 & 32305 \\
\hline Panel B: Men & \multicolumn{6}{|c|}{ Dep Var: Housework Time (hours per day) } \\
\hline WifeEarnsMore & $\begin{array}{l}-0.04 \\
(0.03)\end{array}$ & $\begin{array}{l}-0.03 \\
(0.03)\end{array}$ & $\begin{array}{l}-0.05 \\
(0.03)\end{array}$ & $\begin{array}{l}-0.04 \\
(0.03)\end{array}$ & $\begin{array}{l}-0.00 \\
(0.03)\end{array}$ & $\begin{array}{l}-0.05 \\
(0.03)\end{array}$ \\
\hline WifeEarnsMore*East & & & $\begin{array}{c}0.03 \\
(0.04)\end{array}$ & & & $\begin{array}{c}0.05 \\
(0.04)\end{array}$ \\
\hline East & & & $\begin{array}{c}0.15^{* * *} \\
(0.05)\end{array}$ & & & \\
\hline Observations & 20836 & 11469 & 32305 & 20836 & 11469 & 32305 \\
\hline Panel C: Couple & \multicolumn{6}{|c|}{ Dep Var: Housework Time Gap (Woman's - Man's) } \\
\hline WifeEarnsMore & $\begin{array}{c}0.07 \\
(0.06)\end{array}$ & $\begin{array}{l}-0.02 \\
(0.05)\end{array}$ & $\begin{array}{l}0.10^{*} \\
(0.06)\end{array}$ & $\begin{array}{c}0.17^{* * *} \\
(0.05)\end{array}$ & $\begin{array}{l}-0.01 \\
(0.04)\end{array}$ & $\begin{array}{c}0.20^{* * *} \\
(0.05)\end{array}$ \\
\hline WifeEarnsMore*East & & & $\begin{array}{l}-0.15^{*} \\
(0.08)\end{array}$ & & & $\begin{array}{c}-0.23^{* * *} \\
(0.06)\end{array}$ \\
\hline East & & & $\begin{array}{c}-0.62^{* * *} \\
(0.11)\end{array}$ & & & \\
\hline Individual fixed-effects & No & No & No & Yes & Yes & Yes \\
\hline Individuals & 4043 & 1902 & 5945 & 4043 & 1902 & 5945 \\
\hline Observations & 20836 & 11469 & 32305 & 20836 & 11469 & 32305 \\
\hline
\end{tabular}

Notes: ${ }^{*} \mathrm{p}<0.1,{ }^{* *} \mathrm{p}<0.05,{ }^{* * *} \mathrm{p}<0.01$. The data comes from the German SocioEconomic Panel using all the waves from 1991 until 2012. The sample contains only dual earner married couples. Standard errors clustered at the individual level are given in parentheses. East is a dummy equals to 1 when both spouses lived in the former GDR before 1989. Controls: relative income between spouses, log of household income, respondent and partner's log of individual income, respondent and partner's age and age squared, respondent and partner's education level, a dummy controlling for the presence of children, year fixed-effects, Land fixed-effects and individual fixed-effects (columns 4,5 and 6). 
Table D6: Housework Time and Relative Income - Controlling for Paid-Work Time and Excluding Log Individual Incomes

\begin{tabular}{|c|c|c|c|c|c|c|}
\hline \multicolumn{7}{|c|}{ Dependent variable: Woman's Housework Time (hours per day) } \\
\hline & $\begin{array}{l}\text { West } \\
(1)\end{array}$ & $\begin{array}{c}\text { East } \\
(2)\end{array}$ & $\begin{array}{l}\text { All } \\
(3)\end{array}$ & $\begin{array}{c}\text { West } \\
(4)\end{array}$ & $\begin{array}{c}\text { East } \\
(5)\end{array}$ & $\begin{array}{l}\text { All } \\
\text { (6) }\end{array}$ \\
\hline Panel A: Women & \multicolumn{6}{|c|}{ Dep Var: Housework Time (hours per day) } \\
\hline WifeEarnsMore & $\begin{array}{c}0.25^{* * *} \\
(0.05)\end{array}$ & $\begin{array}{c}0.00 \\
(0.04)\end{array}$ & $\begin{array}{c}0.26^{* * *} \\
(0.05)\end{array}$ & $\begin{array}{c}0.20^{* * *} \\
(0.04)\end{array}$ & $\begin{array}{c}0.01 \\
(0.03)\end{array}$ & $\begin{array}{c}0.22^{* * *} \\
(0.04)\end{array}$ \\
\hline WifeEarnsMore*East & & & $\begin{array}{c}-0.27^{* * * *} \\
(0.06)\end{array}$ & & & $\begin{array}{c}-0.22^{* * *} \\
(0.05)\end{array}$ \\
\hline East & & & $\begin{array}{c}-0.56^{* * *} \\
(0.10)\end{array}$ & & & \\
\hline Observations & 20836 & 11469 & 32305 & 20836 & 11469 & 32305 \\
\hline Panel B: Men & \multicolumn{6}{|c|}{ Dep Var: Housework Time (hours per day) } \\
\hline WifeEarnsMore & $\begin{array}{l}-0.02 \\
(0.03)\end{array}$ & $\begin{array}{l}-0.01 \\
(0.03)\end{array}$ & $\begin{array}{l}-0.02 \\
(0.03)\end{array}$ & $\begin{array}{l}-0.03 \\
(0.03)\end{array}$ & $\begin{array}{c}0.00 \\
(0.02)\end{array}$ & $\begin{array}{l}-0.03 \\
(0.03)\end{array}$ \\
\hline WifeEarnsMore*East & & & $\begin{array}{c}0.01 \\
(0.04)\end{array}$ & & & $\begin{array}{c}0.04 \\
(0.04)\end{array}$ \\
\hline East & & & $\begin{array}{c}0.14^{* *} \\
(0.05)\end{array}$ & & & \\
\hline Observations & 20836 & 11469 & 32305 & 20836 & 11469 & 32305 \\
\hline Panel C: Couple & \multicolumn{6}{|c|}{ Dep Var: Housework Time Gap (Woman's - Man's) } \\
\hline WifeEarnsMore & $\begin{array}{c}0.27^{* * *} \\
(0.05)\end{array}$ & $\begin{array}{c}0.01 \\
(0.05)\end{array}$ & $\begin{array}{c}0.29 * * * \\
(0.05)\end{array}$ & $\begin{array}{c}0.24 * * * \\
(0.05)\end{array}$ & $\begin{array}{c}0.01 \\
(0.04)\end{array}$ & $\begin{array}{c}0.25 * * * \\
(0.05)\end{array}$ \\
\hline WifeEarnsMore*East & & & $\begin{array}{c}-0.28^{* * *} \\
(0.08)\end{array}$ & & & $\begin{array}{c}-0.26^{* * *} \\
(0.06)\end{array}$ \\
\hline East & & & $\begin{array}{c}-0.69 * * * \\
(0.11)\end{array}$ & & & \\
\hline Individual fixed-effects & No & No & No & Yes & Yes & Yes \\
\hline Individuals & 4043 & 1902 & 5945 & 4043 & 1902 & 5945 \\
\hline Observations & 20836 & 11469 & 32305 & 20836 & 11469 & 32305 \\
\hline
\end{tabular}

Notes: ${ }^{*} \mathrm{p}<0.1,{ }^{* *} \mathrm{p}<0.05,{ }^{* * *} \mathrm{p}<0.01$. The data comes from the German Socio-Economic Panel using all the waves from 1991 until 2012. The sample contains only dual earner married couples. Standard errors clustered at the individual level are given in parentheses. East is a dummy equals to 1 when both spouses lived in the former GDR before 1989. Controls: relative income between spouses, log of household income, respondent and partner's age and age squared, respondent and partner's education level, a dummy controlling for the presence of children, year fixed-effects, Land fixed-effects and individual fixed-effects (columns 4,5 and $6)$. 


\section{D.4 Marriage Instability - Additional Results}

Table D\%: Relative Income and the Risk of Divorce at Different Horizons

\begin{tabular}{lccccc}
\hline \multicolumn{6}{c}{ Dependent variable: Divorced at horizon } \\
\hline & 1 year & 2 years & 3 years & 4 years & 5 years \\
\hline \hline \multirow{2}{*}{ WifeEarnsMore } & $(1)$ & $(2)$ & $(3)$ & $(4)$ & $(5)$ \\
& 0.00 & 0.01 & $0.02^{*}$ & $0.02^{* *}$ & $0.03^{* *}$ \\
WifeEarnsMore*East & $0.01)$ & $(0.01)$ & $(0.01)$ & $(0.01)$ & $(0.02)$ \\
& $(0.01)$ & -0.01 & -0.02 & $-0.03^{* *}$ & $-0.05^{* * *}$ \\
Probability of Divorce & 0.01 & 0.03 & $0.01)$ & $(0.01)$ & $(0.02)$ \\
Couple fixed-effects & Yes & Yes & Yes & Yes & Yes \\
Couples & 4409 & 3867 & 3413 & 3032 & 2782 \\
Observations & 21551 & 18681 & 16414 & 14567 & 13973 \\
\hline
\end{tabular}

Notes: ${ }^{*} \mathrm{p}<0.1,{ }^{* *} \mathrm{p}<0.05,{ }^{* * *} \mathrm{p}<0.01$. The data comes from the German Socio-Economic Panel using all the waves from 1991 until 2012. The sample contains only dual earner married couples. Standard errors clustered at the couple level are given in parentheses. East is a dummy equals to 1 when both spouses lived in the former GDR before 1989. Controls: log of household income, respondent and partner's age and age squared, respondent and partner's education level, a dummy controlling for the presence of children, year fixed-effects, Land fixed-effects and couple fixed-effects (columns 4,5 and 6). 


\section{D.5 Labor Market Participation - Additional Results}

Table D8: Labor Market Participation and Potential Relative Income of Women - Including Marital Status in Heckman Selection

\begin{tabular}{|c|c|c|c|c|c|c|}
\hline & \multicolumn{3}{|c|}{$\begin{array}{c}\text { Women } \\
\text { Out of the labor force in } T\end{array}$} & \multicolumn{3}{|c|}{$\begin{array}{c}\text { Men } \\
\text { Out of the labor force in } T\end{array}$} \\
\hline & $\begin{array}{c}\text { West } \\
(1)\end{array}$ & $\begin{array}{c}\text { East } \\
(2) \\
\end{array}$ & $\begin{array}{c}\text { All } \\
(3) \\
\end{array}$ & $\begin{array}{c}\text { West } \\
(4) \\
\end{array}$ & $\begin{array}{c}\text { East } \\
(5) \\
\end{array}$ & $\begin{array}{c}\text { All } \\
(6) \\
\end{array}$ \\
\hline WifeEarnsMore Potentially & $\begin{array}{c}0.05 * * * \\
(0.01)\end{array}$ & $\begin{array}{c}-0.02^{* *} \\
(0.01)\end{array}$ & $\begin{array}{c}0.04^{* * *} \\
(0.01)\end{array}$ & & & \\
\hline WifeEarnsMore Potentially*East & & & $\begin{array}{c}-0.06^{* * *} \\
(0.02)\end{array}$ & & & \\
\hline ManEarnsMore Potentially & & & & $\begin{array}{c}-0.04^{* * *} \\
(0.02)\end{array}$ & $\begin{array}{l}-0.01 \\
(0.01)\end{array}$ & $\begin{array}{c}-0.04^{* * *} \\
(0.02)\end{array}$ \\
\hline ManEarnsMore Potentially*East & & & & & & $\begin{array}{c}0.03^{* *} \\
(0.02)\end{array}$ \\
\hline East & & & $\begin{array}{c}-0.14^{* *} \\
(0.05)\end{array}$ & & & $\begin{array}{c}-0.11^{* *} \\
(0.05)\end{array}$ \\
\hline Observations & 35848 & 14290 & 50138 & 32104 & 14647 & 43783 \\
\hline
\end{tabular}

Notes: ${ }^{*} \mathrm{p}<0.1,{ }^{*} \mathrm{p}<0.05,{ }^{* * *} \mathrm{p}<0.01$. The data comes from the German Socio-Economic Panel using all the waves from 1991 until 2012. Standard errors clustered at the individual level are given in parentheses. Controls include log of husband income, log of household income, respondent and partners' age and age squared, respondent and partner's education level along with year fixed-effects and Land fixed-effects. 


\section{E Robustness}

\section{E.1 Alternative Definitions of East vs West Couples- Does it Matter which Spouse is from the East/West?}

In this section, we consider whether our results are sensitive to the origin of the husband and the wife before 1989. In Table E1, we first display descriptive statistics on "purely West", "purely East" and mixed couples. We see that mixed couples are somehow in between the two other types of couples. For instance, in 18\% of mixed couples, the wife earns more than her husband whereas this figure is respectively of $10 \%$ and $29 \%$ for purely West and purely East couples. We observe a similar pattern for the other variables related to gender norms such as relative income, housework time or paid work time. Looking only at mixed couples in Table E2, we observe little difference depending on whether it is the wife or the husband who used to live in the GDR. Overall, relative income and the probability that WifeEarnsMore seem slightly higher in couples where the wife comes from the East. Yet, the small number of observations makes it difficult to draw definitive conclusions.

In Table E3, we replicate the main analysis, using female housework time as the outcome. We use this specification because it appears to be the most precisely estimated on the full sample and consequently the most likely to present interesting heterogeneous pattern. We perform this analysis for three groups: "pure couples", only husbands from the East/West and only wives from the East/West. We cannot run this analysis directly on mixed couples because of the small number of observations (726 for mixed couples against respectively 12,114 and 22,091 for Eastern and Western couples). We do not observe different patterns in Panel A ("pure" couples), Panel B (only husbands from East/West) or Panel C (only wives from East/West). In the three types of couples, we see that when a wife earns more than her husband, she increases the time she spends on housework when she lives in the West but not in the East. 
Table E1: Descriptive Statistics of Couples Depending on Where they Lived Before 1989.

\begin{tabular}{|c|c|c|c|c|c|c|}
\hline & \multicolumn{2}{|c|}{$\begin{array}{l}\text { Both Lived } \\
\text { only in FRG }\end{array}$} & \multicolumn{2}{|c|}{$\begin{array}{c}\text { Both Lived } \\
\text { only in GDR }\end{array}$} & \multicolumn{2}{|c|}{ Mixed Couple } \\
\hline & Mean & S.D. & Mean & S.D. & Mean & S.D. \\
\hline Woman From East & 0.00 & 0.00 & 1.00 & 0.00 & 0.72 & 0.45 \\
\hline Man From East & 0.00 & 0.00 & 1.00 & 0.00 & 0.28 & 0.45 \\
\hline Relative Income & 0.29 & 0.17 & 0.42 & 0.15 & 0.35 & 0.19 \\
\hline WifeEarnsMore & 0.11 & 0.31 & 0.29 & 0.45 & 0.18 & 0.38 \\
\hline Woman's Housework Time & 2.61 & 1.50 & 1.98 & 1.09 & 2.09 & 1.22 \\
\hline Man's Housework Time & 0.61 & 0.72 & 0.68 & 0.73 & 0.75 & 0.98 \\
\hline Hswk Woman - Hswk Man & 1.99 & 1.73 & 1.30 & 1.32 & 1.34 & 1.61 \\
\hline Actual Weekly Work Time & 27.03 & 13.29 & 37.72 & 10.40 & 31.59 & 13.40 \\
\hline Actual Weekly Work Time & 44.60 & 9.81 & 45.70 & 9.77 & 43.64 & 9.98 \\
\hline Income $\mathrm{HH}$ & 3679.14 & 2405.09 & 2660.94 & 1234.34 & 3216.06 & 1210.66 \\
\hline Income Woman & 973.45 & 835.55 & 1056.71 & 640.34 & 1067.98 & 739.85 \\
\hline Income Man & 2456.87 & 1703.53 & 1477.82 & 913.59 & 2016.15 & 975.10 \\
\hline Hourly Wage Woman & 8.62 & 5.43 & 6.79 & 4.11 & 8.16 & 4.59 \\
\hline Hourly Wage Man & 13.14 & 8.62 & 7.84 & 4.99 & 11.32 & 5.75 \\
\hline Woman's Age & 43.64 & 8.46 & 42.90 & 8.49 & 38.86 & 8.62 \\
\hline Man's Age & 46.26 & 8.73 & 45.23 & 8.68 & 42.83 & 8.52 \\
\hline Kids in HH $(1=$ YES $)$ & 0.68 & 0.47 & 0.72 & 0.45 & 0.62 & 0.49 \\
\hline Observations & 22091 & & 12114 & & 726 & \\
\hline
\end{tabular}

Notes: The data comes from the German Socio-Economic Panel using all the waves from 1991 until 2012. Descriptive statistics are based on the main sample: married couples with positive income. Eastern (Western) couples are those in which both spouses lived in GDR (FRG) before 1989. Number of housework or paid-work hours per day. 
Table E2: Descriptive Statistics of Mixed Couples Depending on Who is from the East.

\begin{tabular}{lcccc}
\hline & \multicolumn{2}{c}{ Woman from East } & \multicolumn{2}{c}{ Man from East } \\
\hline & Mean & S.D. & Mean & S.D. \\
Woman From East & 1.00 & 0.00 & 0.00 & 0.00 \\
Man From East & 0.00 & 0.00 & 1.00 & 0.00 \\
Relative Income & 0.35 & 0.19 & 0.34 & 0.18 \\
WifeEarnsMore & 0.18 & 0.39 & 0.17 & 0.38 \\
Woman's Housework Time & 2.11 & 1.28 & 2.04 & 1.06 \\
Man's Housework Time & 0.73 & 0.95 & 0.79 & 1.07 \\
Hswk Woman - Hswk Man & 1.38 & 1.64 & 1.25 & 1.54 \\
Actual Weekly Work Time & 32.04 & 13.33 & 30.43 & 13.56 \\
Actual Weekly Work Time & 43.19 & 10.45 & 44.82 & 8.57 \\
Income HH & 3158.21 & 1174.68 & 3368.22 & 1291.27 \\
Income Woman & 1054.47 & 757.74 & 1103.54 & 691.14 \\
Income Man & 1958.54 & 909.68 & 2167.66 & 1117.61 \\
Hourly Wage Woman & 7.81 & 4.35 & 9.06 & 5.07 \\
Hourly Wage Man & 11.26 & 5.85 & 11.49 & 5.51 \\
Woman's Age & 39.05 & 8.37 & 38.38 & 9.24 \\
Man's Age & 43.33 & 8.60 & 41.49 & 8.17 \\
Kids in HH (1=YES) & 0.61 & 0.49 & 0.64 & 0.48 \\
Observations & 526 & & 200 & \\
\hline
\end{tabular}

Notes: The data comes from the German Socio-Economic Panel using all the waves from 1991 until 2012. Descriptive statistics are based on the main sample: married couples with positive income. Eastern (Western) couples are those in which both spouses lived in GDR (FRG) before 1989. Number of housework or paid-work hours per day. 
Table E3: Housework Time and Relative Income Depending on Whether Husband or Wife Has Lived in GDR or FRG

\begin{tabular}{|c|c|c|c|c|c|c|}
\hline \multicolumn{7}{|c|}{ Dependent variable: Woman's Housework Time (hours per day) } \\
\hline & $\begin{array}{c}\text { West } \\
(1)\end{array}$ & $\begin{array}{c}\text { East } \\
(2)\end{array}$ & $\begin{array}{l}\text { All } \\
(3) \\
\end{array}$ & $\begin{array}{c}\text { West } \\
(4) \\
\end{array}$ & $\begin{array}{c}\text { East } \\
(5) \\
\end{array}$ & $\begin{array}{l}\text { All } \\
(6) \\
\end{array}$ \\
\hline \multicolumn{7}{|c|}{ Panel A: East $=1$ if Both from East } \\
\hline WifeEarnsMore & $\begin{array}{c}0.10^{* *} \\
(0.05)\end{array}$ & $\begin{array}{l}-0.02 \\
(0.04)\end{array}$ & $\begin{array}{c}0.12^{* *} \\
(0.05)\end{array}$ & $\begin{array}{c}0.17^{* * *} \\
(0.04)\end{array}$ & $\begin{array}{c}0.01 \\
(0.03)\end{array}$ & $\begin{array}{c}0.18^{* * *} \\
(0.04)\end{array}$ \\
\hline WifeEarnsMore*East & & & $\begin{array}{c}-0.14^{* *} \\
(0.06)\end{array}$ & & & $\begin{array}{c}-0.18^{* * *} \\
(0.05)\end{array}$ \\
\hline East & & & $\begin{array}{c}-0.67^{* * *} * \\
(0.09)\end{array}$ & & & \\
\hline Observations & 22091 & 12114 & 34205 & 22091 & 12114 & 34205 \\
\hline \multicolumn{7}{|c|}{ Panel B: East $=1$ if Man from East } \\
\hline WifeEarnsMore & $\begin{array}{c}0.11^{* *} \\
(0.05)\end{array}$ & $\begin{array}{l}-0.01 \\
(0.04)\end{array}$ & $\begin{array}{c}0.13^{* * *} \\
(0.05)\end{array}$ & $\begin{array}{c}0.18^{* * *} \\
(0.04)\end{array}$ & $\begin{array}{c}0.01 \\
(0.03)\end{array}$ & $\begin{array}{c}0.19^{* * *} \\
(0.04)\end{array}$ \\
\hline WifeEarnsMore*East & & & $\begin{array}{c}-0.15^{* *} \\
(0.06)\end{array}$ & & & $\begin{array}{c}-0.19^{* * *} \\
(0.05)\end{array}$ \\
\hline East & & & $\begin{array}{c}-0.64^{* * *} \\
(0.09)\end{array}$ & & & \\
\hline Observations & 22617 & 12314 & 34931 & 22617 & 12314 & 34931 \\
\hline \multicolumn{7}{|c|}{ Panel C: East $=1$ if Woman from East } \\
\hline WifeEarnsMore & $\begin{array}{c}0.11^{* *} \\
(0.05)\end{array}$ & $\begin{array}{l}-0.01 \\
(0.04)\end{array}$ & $\begin{array}{c}0.13^{* * *} \\
(0.05)\end{array}$ & $\begin{array}{c}0.18^{* * *} \\
(0.04)\end{array}$ & $\begin{array}{c}0.01 \\
(0.03)\end{array}$ & $\begin{array}{c}0.19^{* * *} \\
(0.04)\end{array}$ \\
\hline WifeEarnsMore*East & & & $\begin{array}{c}-0.15^{* *} \\
(0.06)\end{array}$ & & & $\begin{array}{c}-0.19^{* * *} \\
(0.05)\end{array}$ \\
\hline East & & & $\begin{array}{c}-0.64^{* * *} \\
(0.09)\end{array}$ & & & \\
\hline Observations & 22617 & 12314 & 34931 & 22617 & 12314 & 34931 \\
\hline
\end{tabular}

Notes: $* \mathrm{p}<0.1,{ }^{* *} \mathrm{p}<0.05,{ }^{* * *} \mathrm{p}<0.01$. The data comes from the German SocioEconomic Panel using all the waves from 1991 until 2012. The sample contains only dual earner married couples. Standard errors clustered at the individual level are given in parentheses. East is a dummy equals to 1 when both spouses (Panel A), the man (Panel B) or the woman (Panel C) lived in the former GDR before 1989. Controls: relative income between spouses, log of household income, respondent and partner's log of individual income, respondent and partner's age and age squared, respondent and partner's education level, a dummy controlling for the presence of children, year fixed-effects, Land fixed-effects and individual fixed-effects (columns 4,5 and 6). 


\section{E.2 Replication of Results Based on the Geographical Divide Between East and West Länder}

This section replicates the results with a definition of East based on the geographical divide between Eastern and Western Länder. Here, the dummy East equals 1 if the individual/couple currently lives in the former regions of the GDR (and 0 otherwise).

Table E4 provides descriptive statistics of the sample. Similarly to the sample used in the "biographic" definition, we see that women living in East Germany earn a higher share of the household income (42\% vs 15\%) and are more likely to earn more than their husband (30\% vs 11\%). These households are also poorer on average and of similar age.

Table E5 displays the results obtained with the geographical definition. They are very similar to those obtained with the biographical definition. When a woman earns more than her husband, she is more likely to increase the time spent on housework (Panel A), the couple is more likely to divorce (Panel B) and she is more likely to withdraw from the labor market (Panel C), in the West but not in the East. In column 6, using individual fixed-effects specification, we see that the coefficient WifeEarnsMore and WifeEarnsMore * East always offset each other. 
Table E4: Descriptive Statistics of the East/West Samples: Geographical Divide

\begin{tabular}{lcccccccc}
\hline & \multicolumn{3}{c}{ West Germany } & \multicolumn{5}{c}{ East Germany } \\
\hline & Mean & S.D. & Min & Max & Mean & S.D. & Min & Max \\
\hline Woman's Share of Income & 0.29 & 0.17 & 0 & 1 & 0.42 & 0.15 & 0 & 1 \\
WifeEarnsMore & 0.11 & 0.31 & 0 & 1 & 0.30 & 0.46 & 0 & 1 \\
Woman's Housework Time & 2.58 & 1.48 & 0 & 14 & 1.99 & 1.08 & 0 & 12 \\
Man's Housework Time & 0.62 & 0.73 & 0 & 16 & 0.66 & 0.73 & 0 & 10 \\
Hswk Woman - Hswk Man & 1.96 & 1.72 & -15 & 13 & 1.33 & 1.32 & -9 & 12 \\
Paid Work Time Woman & 27.28 & 13.26 & 1 & 80 & 38.01 & 10.25 & 1 & 80 \\
Paid Work Time Man & 44.56 & 9.80 & 1 & 80 & 45.79 & 9.83 & 1 & 80 \\
Income HH (Euros) & 3608.42 & 2336.48 & 10 & 200000 & 2653.50 & 1284.20 & 102 & 16259 \\
Income Woman (Euros) & 964.69 & 808.57 & 2 & 30170 & 1055.89 & 658.23 & 17 & 15000 \\
Income Man (Euros) & 2403.01 & 1656.72 & 46 & 99999 & 1461.53 & 941.68 & 25 & 20452 \\
Hourly Wage Woman & 8.49 & 5.31 & 0 & 129 & 6.74 & 4.18 & 0 & 96 \\
Hourly Wage Man & 12.87 & 8.41 & 0 & 392 & 7.74 & 5.11 & 0 & 138 \\
Woman's Age & 43.13 & 8.64 & 20 & 65 & 42.97 & 8.49 & 19 & 65 \\
Man's Age & 45.77 & 8.87 & 20 & 65 & 45.29 & 8.64 & 22 & 65 \\
Kids in HH (1=YES) & 0.67 & 0.47 & 0 & 1 & 0.73 & 0.45 & 0 & 1 \\
Observations & 23662 & & & & 10897 & & & \\
\hline
\end{tabular}

Notes: The data comes from the German Socio-Economic Panel, using all the waves from 1991 until 2012. Descriptive statistics are based on the main sample: married couples with positive income. People are in the East (resp. West) sample if they currently live in Länder that used to be part of the former GDR (resp. FRG) and have the German nationality. 
Table E5: The Consequences of Violating the Male Breadwinner norm in Eastern versus Western Länder. Geographical Divide

\begin{tabular}{|c|c|c|c|c|c|c|}
\hline & $\begin{array}{l}\text { West } \\
(1)\end{array}$ & $\begin{array}{c}\text { East } \\
(2)\end{array}$ & $\begin{array}{l}\text { All } \\
(3)\end{array}$ & $\begin{array}{c}\text { West } \\
(4)\end{array}$ & $\begin{array}{c}\text { East } \\
(5)\end{array}$ & $\begin{array}{l}\text { All } \\
(6)\end{array}$ \\
\hline Panel $A$ & \multicolumn{6}{|c|}{ Dep. Var.: Female Housework Time (Hours per day) } \\
\hline WifeEarnsMore & $\begin{array}{c}0.14^{* * *} \\
(0.05)\end{array}$ & $\begin{array}{l}-0.04 \\
(0.04)\end{array}$ & $\begin{array}{c}0.16^{* * *} \\
(0.05)\end{array}$ & $\begin{array}{c}0.17^{* * *} \\
(0.04)\end{array}$ & $\begin{array}{c}0.02 \\
(0.03)\end{array}$ & $\begin{array}{c}0.19^{* * *} \\
(0.04)\end{array}$ \\
\hline WifeEarnsMore*EastGeo & & & $\begin{array}{c}-0.19 * * * \\
(0.06)\end{array}$ & & & $\begin{array}{c}-0.18^{* * *} \\
(0.05)\end{array}$ \\
\hline EastGeo & & & $\begin{array}{c}-0.90^{* * *} \\
(0.10)\end{array}$ & & & $\begin{array}{l}-0.49 \\
(0.32)\end{array}$ \\
\hline Individual fixed-effects & No & No & No & Yes & Yes & Yes \\
\hline Individuals & 4642 & 1888 & 6479 & 4642 & 1888 & 6479 \\
\hline Observations & 23662 & 10897 & 34559 & 23662 & 10897 & 34559 \\
\hline Panel B & \multicolumn{6}{|c|}{ Dep. Var.: Divorced within a 5-year time horizon (1=Yes) } \\
\hline WifeEarnsMore & $\begin{array}{c}0.02 \\
(0.02)\end{array}$ & $\begin{array}{l}0.02^{*} \\
(0.01)\end{array}$ & $\begin{array}{c}0.02 \\
(0.02)\end{array}$ & $\begin{array}{c}0.03^{* *} \\
(0.01)\end{array}$ & $\begin{array}{l}-0.01 \\
(0.01)\end{array}$ & $\begin{array}{c}0.03^{* *} \\
(0.01)\end{array}$ \\
\hline WifeEarnsMore*EastGeo & & & $\begin{array}{c}0.01 \\
(0.02)\end{array}$ & & & $\begin{array}{c}-0.03^{* *} \\
(0.01)\end{array}$ \\
\hline EastGeo & & & $\begin{array}{l}-0.03 \\
(0.02)\end{array}$ & & & \\
\hline Couple fixed-effects & No & No & No & Yes & Yes & Yes \\
\hline Couples & 1798 & 676 & 2460 & 1798 & 676 & 2460 \\
\hline Observations & 9946 & 4219 & 14165 & 9946 & 4219 & 14165 \\
\hline Panel $C$ & \multicolumn{6}{|c|}{ Dep. Var.: Woman out of the labor market in $T+1$ (1=Yes) } \\
\hline WifeEarnsMore & $\begin{array}{c}0.02^{* * *} \\
(0.00)\end{array}$ & $\begin{array}{c}0.00 \\
(0.00)\end{array}$ & $\begin{array}{c}0.02^{* * *} \\
(0.00)\end{array}$ & $\begin{array}{c}0.01^{* *} \\
(0.00)\end{array}$ & $\begin{array}{l}-0.00 \\
(0.00)\end{array}$ & $\begin{array}{c}0.01^{* *} \\
(0.00)\end{array}$ \\
\hline WifeEarnsMore*EastGeo & & & $\begin{array}{c}-0.02^{* * *} \\
(0.00)\end{array}$ & & & $\begin{array}{c}-0.01^{* *} \\
(0.01)\end{array}$ \\
\hline EastGeo & & & $\begin{array}{c}-0.03^{* * *} \\
(0.01)\end{array}$ & & & \\
\hline Individual fixed-effects & No & No & No & Yes & Yes & Yes \\
\hline Individuals & 4132 & 1647 & 5728 & 4132 & 1647 & 5728 \\
\hline Observations & 24574 & 11259 & 35833 & 24574 & 11259 & 35833 \\
\hline
\end{tabular}

Notes: ${ }^{*} \mathrm{p}<0.1,{ }^{* *} \mathrm{p}<0.05,{ }^{* * *} \mathrm{p}<0.01$. The data comes from the German Socio-Economic Panel using all the waves from 1991 until 2012. The sample contains only dual earner married couples. Standard errors clustered at the individual level are given in parentheses. East is a dummy equals to 1 (resp. 0) if the individual currently lives in Länder that used to be part of the former GDR (resp. FRG) and have the German nationality. Controls include log of household income, respondent and partners' age and age squared, respondent and partner's education level, a dummy controlling for the presence of children, year fixed-effects, Land fixed-effects and individual fixed-effects (column 4,5 and 6). Panel A and C further control for relative 20 rome and Panel A and B for respondent and partner's $\log$ of individual income. 
Table E6: Attitudes to Work in Eastern Versus Western Länder. Geographical Divide

\begin{tabular}{lccccc}
\hline \multicolumn{5}{c}{ Dependent Variable: } & How Important is ... for your satisfaction ? \\
\hline & $(1)$ & $(2)$ & $(3)$ & $(4)$ & $(5)$ \\
& Work & Success at Work & A Successful Career & Marriage & Family \\
\hline \multirow{4}{*}{ EastGeo } & & & & & \\
& $0.106^{* * *}$ & $0.026^{* *}$ & $0.026^{*}$ & 0.009 & 0.012 \\
Female & $(0.018)$ & $(0.011)$ & $(0.015)$ & $(0.011)$ & $(0.010)$ \\
& $-0.178^{* * *}$ & $-0.112^{* * *}$ & $-0.123^{* * *}$ & $0.038^{* * *}$ & $0.038^{* * *}$ \\
Female*EastGeo & $(0.014)$ & $(0.008)$ & $(0.012)$ & $(0.007)$ & $(0.002)$ \\
& $0.115^{* * *}$ & $0.085^{* * *}$ & $0.061^{* * *}$ & -0.014 & $0.017^{*}$ \\
& $(0.019)$ & $(0.014)$ & $(0.018)$ & $(0.012)$ & $(0.010)$ \\
Observations & 12,762 & 22,906 & & & \\
\hline
\end{tabular}

Notes: ${ }^{*} \mathrm{p}<0.1,{ }^{* *} \mathrm{p}<0.05,{ }^{* * *} \mathrm{p}<0.01$. The data comes from the German Socio-Economic Panel using all the waves from 1991 until 2012. The sample contains only married couples. Standard errors clustered at the individual level are given in parentheses. East is a dummy equals to 1 (resp. 0) if the individual currently lives in Länder that used to be part of the former GDR (resp. FRG) and has the German nationality. Controls: respondent and partner's age and age squared, respondent and partner's education level, a dummy controlling for the presence of children, a dummy representing whether the woman is working, a dummy representing whether the man is working and their interaction with the East (Geographical) dummy, year fixed-effects and Land fixed-effects. 
E.3 Alternative Samples - Unmarried and Single-Earner Couples 
Table E7: Consequences of Violating the Male Breadwinner Norm. Alternative Samples

\begin{tabular}{|c|c|c|c|c|}
\hline & $(1)$ & $(2)$ & $(3)$ & $(4)$ \\
\hline & \multicolumn{4}{|c|}{ Dep Var: Woman's Housework Time (hours per day) } \\
\hline WifeEarnsMore & $\begin{array}{c}0.18^{* * *} \\
(0.04)\end{array}$ & $\begin{array}{c}0.14^{* * *} \\
(0.04)\end{array}$ & $\begin{array}{c}0.18^{* * *} \\
(0.04)\end{array}$ & $\begin{array}{c}0.16^{* * *} \\
(0.04)\end{array}$ \\
\hline WifeEarnsMore*East & $\begin{array}{c}-0.18^{* * *} \\
(0.05)\end{array}$ & $\begin{array}{c}-0.15^{* * *} \\
(0.05)\end{array}$ & $\begin{array}{c}-0.18^{* * *} \\
(0.05)\end{array}$ & $\begin{array}{c}-0.17^{* * *} \\
(0.05)\end{array}$ \\
\hline Marital Status & Only Married & Only Married & All couples & All couples \\
\hline Only Dual Earner & Yes & No & Yes & No \\
\hline Individual fixed-effects & Yes & Yes & Yes & Yes \\
\hline Individuals & 6104 & 7490 & 7228 & 8660 \\
\hline \multirow{2}{*}{ Observations } & 34205 & 44834 & 40226 & 51233 \\
\hline & \multicolumn{4}{|c|}{ Dep Var: Divorced within a 5-year time horizon (1=Yes) } \\
\hline WifeEarnsMore & $\begin{array}{c}0.03^{* *} \\
(0.02)\end{array}$ & $\begin{array}{c}0.04^{* *} \\
(0.02)\end{array}$ & & \\
\hline WifeEarnsMore*East & $\begin{array}{c}-0.05^{* * *} \\
(0.02)\end{array}$ & $\begin{array}{c}-0.05^{* * *} \\
(0.02)\end{array}$ & & \\
\hline Marital Status & Only Married & Only Married & & \\
\hline Only Dual Earner & Yes & No & & \\
\hline Individual fixed-effects & Yes & Yes & & \\
\hline Individuals & 2782 & 3284 & & \\
\hline \multirow[t]{2}{*}{ Observations } & 13973 & 16221 & & \\
\hline & \multicolumn{4}{|c|}{ Dep Var: Woman's Out of the Labor Market T+1 (1=Yes, } \\
\hline WifeEarnsMore & $\begin{array}{l}0.01^{*} \\
(0.00)\end{array}$ & $\begin{array}{c}0.01 \\
(0.01)\end{array}$ & $\begin{array}{c}0.01^{* *} \\
(0.00)\end{array}$ & $\begin{array}{c}0.01^{* *} \\
(0.00)\end{array}$ \\
\hline WifeEarnsMore*East & $\begin{array}{l}-0.01 \\
(0.01)\end{array}$ & $\begin{array}{l}-0.00 \\
(0.01)\end{array}$ & $\begin{array}{c}-0.01^{*} \\
(0.00)\end{array}$ & $\begin{array}{l}-0.01 \\
(0.01)\end{array}$ \\
\hline Marital Status & Only Married & Only Married & All couples & All couples \\
\hline Only Dual Earner & Yes & No & Yes & No \\
\hline Individual fixed-effects & Yes & Yes & Yes & Yes \\
\hline Individuals & 4765 & 5507 & 5335 & 6073 \\
\hline Observations & 34274 & 44793 & 39722 & 50562 \\
\hline
\end{tabular}

Notes: ${ }^{*} \mathrm{p}<0.1,{ }^{* *} \mathrm{p}<0.05,{ }^{* * *} \mathrm{p}<0.01$. The data comes from the German Socio-Economic Panel using all the waves from 1991 until 2012. Standard errors clustered at the individual level are given in parentheses. East is a dummy equals to 1 when both spouses lived in the former GDR before 1989. Income controls include log of household income, respondent and partners' age and age squared, respondent and partner's education level, a dummy controlling for the presence of children, a dummy controlling for whether only the woman is working and a dummy controlling for whether only the man is working, both alone and interacted with East, year fixed-effects, Land fixed-effects and individual fixed-effects. Panel $\mathrm{A}$ and $\mathrm{C}$ further control for relative income and Panel A and B for respondent and partner's log of individual income. 
Table E8: Consequences of Violating the Male Breadwinner Norm. Alternative Samples - Sensitivity to Excluding Outliers

\begin{tabular}{|c|c|c|c|}
\hline & $(1)$ & $(2)$ & (3) \\
\hline & \multicolumn{3}{|c|}{ Dep Var: Woman's Housework Time (hours per day) } \\
\hline WifeEarnsMore & $\begin{array}{l}0.17^{* * *} \\
(0.04)\end{array}$ & $\begin{array}{l}0.19^{* * *} \\
(0.04)\end{array}$ & $\begin{array}{l}0.17^{* * *} \\
(0.04)\end{array}$ \\
\hline WifeEarnsMore*East & $\begin{array}{l}-0.15^{* * *} \\
(0.05)\end{array}$ & $\begin{array}{l}-0.19 * * * \\
(0.05)\end{array}$ & $\begin{array}{l}-0.16^{* * *} \\
(0.05)\end{array}$ \\
\hline Outlier's Excluded Sex & Woman & Man & Both \\
\hline Individual fixed-effects & Yes & Yes & Yes \\
\hline Individuals & 6063 & 6048 & 6008 \\
\hline \multirow[t]{2}{*}{ Observations } & 33604 & 33584 & 33029 \\
\hline & \multicolumn{3}{|c|}{ Dep Var: Divorced within a 5-year time horizon $(1=Y e s)$} \\
\hline WifeEarnsMore & $\begin{array}{l}0.03^{* *} \\
(0.02)\end{array}$ & $\begin{array}{l}0.03^{*} \\
(0.02)\end{array}$ & $\begin{array}{l}0.03^{* *} \\
(0.02)\end{array}$ \\
\hline WifeEarnsMore*East & $\begin{array}{l}-0.05^{* * *} \\
(0.02)\end{array}$ & $\begin{array}{l}-0.05^{* * *} \\
(0.02)\end{array}$ & $\begin{array}{l}-0.05^{* * *} \\
(0.02)\end{array}$ \\
\hline Outlier's Excluded Sex & Woman & Man & Both \\
\hline Individual fixed-effects & Yes & Yes & Yes \\
\hline Individuals & 2759 & 2761 & 2739 \\
\hline \multirow[t]{2}{*}{ Observations } & 13766 & 13754 & 13567 \\
\hline & \multicolumn{3}{|c|}{ Dep Var: Woman's Out of the Labor Market T+1 (1=Yes) } \\
\hline WifeEarnsMore & $\begin{array}{l}0.01^{*} \\
(0.00)\end{array}$ & $\begin{array}{l}0.01^{*} \\
(0.00)\end{array}$ & $\begin{array}{l}0.01^{*} \\
(0.00)\end{array}$ \\
\hline WifeEarnsMore*East & $\begin{array}{l}-0.01 \\
(0.01)\end{array}$ & $\begin{array}{l}-0.01 \\
(0.01)\end{array}$ & $\begin{array}{l}-0.01 \\
(0.01)\end{array}$ \\
\hline Outlier's Excluded Sex & Woman & Man & Both \\
\hline Individual fixed-effects & Yes & Yes & Yes \\
\hline Individuals & 4746 & 4750 & 4730 \\
\hline Observations & 33664 & 33669 & 33107 \\
\hline
\end{tabular}

Notes: ${ }^{*} \mathrm{p}<0.1,{ }^{*} \mathrm{p}<0.05,{ }^{* * *} \mathrm{p}<0.01$. The data comes from the German Socio-Economic Panel using all the waves from 1991 until 2012. The sample excludes couples where the woman (column 1), the man (column 2) and at least one of them (column 3) has an hourly wage in the top or the bottom $1 \%$ of the distribution. Standard errors clustered at the individual level are given in parentheses. East is a dummy equals to 1 when both spouses lived in the former GDR before 1989. Income controls include log of household income, respondent and partners' age and age squared, respondent and partner's education level, a dummy controlling for the presence of children, a dummy controlling for whether only the woman is working and a dummy controlling for whether only the man is working, both alone and interacted with East, year fixed-effects, Land fixed-effects and individual fixed-effects. Panel A and $\mathrm{C}$ further control for relative income and Panel A and B for respondent and partner's log of individual income. 


\section{E.4 Alternative Specifications - Housework}

Table E9: Woman's Housework Time and Relative Income. Alternative Specifications

\begin{tabular}{|c|c|c|c|c|c|c|c|}
\hline & \multicolumn{6}{|c|}{ Dependent variable: Woman's Housework Time (hours per day) } & \multirow[b]{2}{*}{$(7)$} \\
\hline & $(1)$ & $(2)$ & $(3)$ & $(4)$ & $(5)$ & $(6)$ & \\
\hline WifeEarnsMore & $\begin{array}{c}0.32^{* * *} \\
(0.04)\end{array}$ & $\begin{array}{c}0.32^{* * *} \\
(0.04)\end{array}$ & $\begin{array}{c}0.18^{* * *} \\
(0.04)\end{array}$ & $\begin{array}{c}0.18^{* * *} \\
(0.04)\end{array}$ & $\begin{array}{c}0.19^{* * *} \\
(0.04)\end{array}$ & $\begin{array}{c}0.32^{* * *} \\
(0.04)\end{array}$ & $\begin{array}{c}0.33^{* * *} \\
(0.04)\end{array}$ \\
\hline WifeEarnsMore*East & $\begin{array}{c}-0.26^{* * *} \\
(0.05)\end{array}$ & $\begin{array}{c}-0.26^{* * *} \\
(0.05)\end{array}$ & $\begin{array}{c}-0.17^{* * *} \\
(0.05)\end{array}$ & $\begin{array}{c}-0.18^{* * *} \\
(0.05)\end{array}$ & $\begin{array}{c}-0.18^{* * *} \\
(0.05)\end{array}$ & $\begin{array}{c}-0.27^{* * *} \\
(0.05)\end{array}$ & $\begin{array}{c}-0.28^{* * *} \\
(0.05)\end{array}$ \\
\hline LogIncomeHH & $\begin{array}{c}-0.24^{* * *} \\
(0.03)\end{array}$ & $\begin{array}{l}-0.47 \\
(0.29)\end{array}$ & & $\begin{array}{l}-0.03 \\
(0.04)\end{array}$ & $\begin{array}{l}-0.04 \\
(0.04)\end{array}$ & $\begin{array}{c}-0.26^{* * *} \\
(0.04)\end{array}$ & $\begin{array}{c}-0.28^{* * *} \\
(0.04)\end{array}$ \\
\hline LogIncomeHH_sq & & $\begin{array}{c}0.01 \\
(0.02)\end{array}$ & & & & & \\
\hline LogIncomeW & & & $\begin{array}{c}-0.31^{* * *} \\
(0.07)\end{array}$ & $\begin{array}{c}-0.36^{* * *} \\
(0.07)\end{array}$ & $\begin{array}{c}-0.61^{* *} \\
(0.25)\end{array}$ & & \\
\hline LogIncomeM & & & $\begin{array}{c}-0.16^{* *} \\
(0.08)\end{array}$ & $\begin{array}{l}-0.12 \\
(0.08)\end{array}$ & $\begin{array}{l}-0.42^{*} \\
(0.24)\end{array}$ & & \\
\hline LogIncomeW_sq & & & & & $\begin{array}{c}0.02 \\
(0.02)\end{array}$ & & \\
\hline LogIncomeM_sq & & & & & $\begin{array}{c}0.02 \\
(0.02)\end{array}$ & & \\
\hline HourlyWageW & & & & & & $\begin{array}{c}0.02^{* * *} \\
(0.00)\end{array}$ & $\begin{array}{c}0.05^{* * *} \\
(0.01)\end{array}$ \\
\hline HourlyWageM & & & & & & $\begin{array}{c}-0.00^{* * *} \\
(0.00)\end{array}$ & $\begin{array}{c}-0.01^{* * *} \\
(0.00)\end{array}$ \\
\hline HourlyWageW_sq & & & & & & & $\begin{array}{c}-0.00^{* * *} \\
(0.00)\end{array}$ \\
\hline HourlyWageM_sq & & & & & & & $\begin{array}{l}0.00^{*} \\
(0.00)\end{array}$ \\
\hline Individual fixed-effects & Yes & Yes & Yes & Yes & Yes & Yes & Yes \\
\hline Individuals & 6104 & 6104 & 6274 & 6104 & 6104 & 5945 & 5945 \\
\hline Observations & 34205 & 34205 & 36020 & 34205 & 34205 & 32305 & 32305 \\
\hline
\end{tabular}

Notes: ${ }^{*} \mathrm{p}<0.1,{ }^{* *} \mathrm{p}<0.05,{ }^{* * *} \mathrm{p}<0.01$. The data comes from the German Socio-Economic Panel using all the waves from 1991 until 2012. The sample contains only dual earner married couples. Standard errors clustered at the individual level are given in parentheses. East is a dummy equals to 1 when both spouses lived in the former GDR before 1989. Controls include respondent and partner's age and age squared, respondent and partner's education level, a dummy controlling for the presence of children, year fixed-effects, Land fixed-effects and individual fixed-effects. 


\section{E.5 Alternative Specifications - Marriage Instability}

Table E10: Risk of Divorce and Relative Income. Alternative Specifications

\begin{tabular}{|c|c|c|c|c|c|c|c|}
\hline & \multicolumn{7}{|c|}{ Dependent variable: Divorced within a 5-year time horizon $(1=$ Yes) } \\
\hline & $(1)$ & $(2)$ & $(3)$ & $(4)$ & (5) & $(6)$ & $(7)$ \\
\hline WifeEarnsMore & $\begin{array}{c}0.04^{* * *} \\
(0.01)\end{array}$ & $\begin{array}{c}0.04^{* * *} \\
(0.01)\end{array}$ & $\begin{array}{c}0.03^{* *} \\
(0.02)\end{array}$ & $\begin{array}{c}0.03^{* *} \\
(0.02)\end{array}$ & $\begin{array}{l}0.03^{*} \\
(0.02)\end{array}$ & $\begin{array}{c}0.04^{* *} \\
(0.02)\end{array}$ & $\begin{array}{c}0.04^{* *} \\
(0.02)\end{array}$ \\
\hline WifeEarnsMore*East & $\begin{array}{c}-0.05^{* * *} \\
(0.02)\end{array}$ & $\begin{array}{c}-0.05^{* * *} \\
(0.02)\end{array}$ & $\begin{array}{c}-0.05^{* * *} \\
(0.02)\end{array}$ & $\begin{array}{c}-0.05^{* * *} \\
(0.02)\end{array}$ & $\begin{array}{c}-0.04^{* *} \\
(0.02)\end{array}$ & $\begin{array}{c}-0.05^{* * *} \\
(0.02)\end{array}$ & $\begin{array}{c}-0.05^{* * *} \\
(0.02)\end{array}$ \\
\hline LogIncomeHH & $\begin{array}{l}-0.02^{*} \\
(0.01)\end{array}$ & $\begin{array}{c}-0.22^{* *} \\
(0.09)\end{array}$ & & $\begin{array}{c}-0.02^{* *} \\
(0.01)\end{array}$ & $\begin{array}{c}-0.02^{* * *} \\
(0.01)\end{array}$ & $\begin{array}{l}-0.01 \\
(0.01)\end{array}$ & $\begin{array}{l}-0.01 \\
(0.01)\end{array}$ \\
\hline LogIncomeHH_sq & & $\begin{array}{c}0.01^{* *} \\
(0.01)\end{array}$ & & & & & \\
\hline LogIncomeW & & & $\begin{array}{c}0.01 \\
(0.01)\end{array}$ & $\begin{array}{l}0.02^{*} \\
(0.01)\end{array}$ & $\begin{array}{l}-0.05 \\
(0.06)\end{array}$ & & \\
\hline LogIncomeM & & & $\begin{array}{l}-0.01 \\
(0.01)\end{array}$ & $\begin{array}{l}-0.00 \\
(0.01)\end{array}$ & $\begin{array}{l}-0.06 \\
(0.06)\end{array}$ & & \\
\hline LogIncomeW_sq & & & & & $\begin{array}{c}0.01 \\
(0.00)\end{array}$ & & \\
\hline LogIncomeM_sq & & & & & $\begin{array}{c}0.00 \\
(0.00)\end{array}$ & & \\
\hline HourlyWageW & & & & & & $\begin{array}{c}0.00 \\
(0.00)\end{array}$ & $\begin{array}{c}0.00 \\
(0.00)\end{array}$ \\
\hline HourlyWageM & & & & & & $\begin{array}{c}0.00 \\
(0.00)\end{array}$ & $\begin{array}{c}0.00 \\
(0.00)\end{array}$ \\
\hline HourlyWageW_sq & & & & & & & $\begin{array}{l}-0.00 \\
(0.00)\end{array}$ \\
\hline HourlyWageM_sq & & & & & & & $\begin{array}{l}-0.00 \\
(0.00)\end{array}$ \\
\hline Individual fixed-effects & Yes & Yes & Yes & Yes & Yes & Yes & Yes \\
\hline Individuals & 2782 & 2782 & 2782 & 2782 & 2782 & 2727 & 2727 \\
\hline Observations & 13973 & 13973 & 13973 & 13973 & 13973 & 13215 & 13215 \\
\hline
\end{tabular}

Notes: ${ }^{*} \mathrm{p}<0.1,{ }^{* *} \mathrm{p}<0.05,{ }^{* * *} \mathrm{p}<0.01$. The data comes from the German Socio-Economic Panel using all the waves from 1991 until 2012. The sample contains only dual earner married couples. Standard errors clustered at the couple level are given in parentheses. East is a dummy equals to 1 when both spouses lived in the former GDR before 1989. Controls include respondent and partner's age and age squared, respondent and partner's education level, a dummy controlling for the presence of children, year fixed-effects, Land fixed-effects and couple fixed-effects. 


\section{E.6 Alternative Specifications - Labor Force Participation}

Table E11: Labor Force Participation and Relative Income. Alternative Specifications

\begin{tabular}{|c|c|c|c|c|c|}
\hline & \multicolumn{5}{|c|}{ Dep Var: Woman out of the labor force in $T+1$} \\
\hline & (1) & $(2)$ & $(3)$ & $(4)$ & $(5)$ \\
\hline WifeEarnsMore & $\begin{array}{l}0.01^{*} \\
(0.00)\end{array}$ & $\begin{array}{c}0.01^{*} \\
(0.00)\end{array}$ & $\begin{array}{c}0.01^{* *} \\
(0.00)\end{array}$ & $\begin{array}{l}0.01^{*} \\
(0.00)\end{array}$ & $\begin{array}{l}0.01^{*} \\
(0.00)\end{array}$ \\
\hline WifeEarnsMore*East & $\begin{array}{l}-0.01 \\
(0.01)\end{array}$ & $\begin{array}{l}-0.01 \\
(0.01)\end{array}$ & $\begin{array}{c}-0.01^{*} \\
(0.01)\end{array}$ & $\begin{array}{c}-0.01 \\
(0.01)\end{array}$ & $\begin{array}{l}-0.01 \\
(0.01)\end{array}$ \\
\hline LogIncomeHH & $\begin{array}{c}-0.01^{* * *} \\
(0.00)\end{array}$ & $\begin{array}{l}-0.02 \\
(0.03)\end{array}$ & & $\begin{array}{c}-0.01^{* * *} \\
(0.00)\end{array}$ & $\begin{array}{c}-0.01^{* * *} \\
(0.00)\end{array}$ \\
\hline LogIncomeHH_sq & & $\begin{array}{c}0.00 \\
(0.00)\end{array}$ & & & \\
\hline HourlyWageW & & & $\begin{array}{c}0.00 * * \\
(0.00)\end{array}$ & $\begin{array}{l}0.00^{*} \\
(0.00)\end{array}$ & $\begin{array}{l}-0.00 \\
(0.00)\end{array}$ \\
\hline HourlyWageM & & & $\begin{array}{c}-0.00^{* * *} \\
(0.00)\end{array}$ & $\begin{array}{c}-0.00^{* * *} \\
(0.00)\end{array}$ & $\begin{array}{c}-0.00^{* * *} \\
(0.00)\end{array}$ \\
\hline HourlyWageW_sq & & & & & $\begin{array}{c}0.00 \\
(0.00)\end{array}$ \\
\hline HourlyWageM_sq & & & & & $\begin{array}{c}0.00^{* *} \\
(0.00)\end{array}$ \\
\hline Individual fixed-effects & Yes & Yes & Yes & Yes & Yes \\
\hline Individuals & 5566 & 5566 & 5587 & 5459 & 5459 \\
\hline Observations & 35688 & 35688 & 35306 & 33589 & 33589 \\
\hline
\end{tabular}

Notes: ${ }^{*} \mathrm{p}<0.1,{ }^{* *} \mathrm{p}<0.05,{ }^{* * *} \mathrm{p}<0.01$. The data comes from the German Socio-Economic Panel using all the waves from 1991 until 2012. Standard errors clustered at the individual level are given in parentheses. East is a dummy equals to 1 when both spouses lived in the former GDR before 1989 . Controls include respondent and partners' age and age squared, respondent and partner's education level, a dummy controlling for the presence of children, year fixed-effects, Land fixed-effects and individual fixed-effects. 


\section{E.7 Alternative Clusters}

The main results display estimations which cluster standard errors at the household level. This section tests the robustness of the main results by using larger clusters at the regional level. Table E12 displays the results obtained by clustering the standard errors at the Land level $(n=16)$. Given the small number of Länder, we also present results obtained by clustering the standard errors at the district level $(n=404)$ in Table E13. In both tables, the precision of the estimation is generally similar to the results obtained by clustering standard errors at the household level. In Table E13, which is our preferred estimation given the number of clusters available, we actually obtain smaller standard errors for the outcomes related to housework and labor market participation. Only for divorce, the results are slightly less precise with a p-value of 0.069 for the coefficient related to WifeEarnsMore in column 3. 
Table E12: Consequences of Violating the Male Breadwinner Norm. Clustering at the Land Level

\begin{tabular}{|c|c|c|c|c|c|c|}
\hline & $\begin{array}{l}\text { West } \\
(1)\end{array}$ & $\begin{array}{c}\text { East } \\
(2)\end{array}$ & $\begin{array}{l}\text { All } \\
(3)\end{array}$ & $\begin{array}{c}\text { West } \\
(4)\end{array}$ & $\begin{array}{c}\text { East } \\
(5)\end{array}$ & $\begin{array}{l}\text { All } \\
(6)\end{array}$ \\
\hline Panel $A$ & \multicolumn{6}{|c|}{ Dep. Var.: Female Housework Time (Hours per day) } \\
\hline WifeEarnsMore & $\begin{array}{c}0.10^{* *} \\
(0.04)\end{array}$ & $\begin{array}{l}-0.02 \\
(0.03)\end{array}$ & $\begin{array}{c}0.12^{* * *} \\
(0.04)\end{array}$ & $\begin{array}{c}0.17 * * * \\
(0.05)\end{array}$ & $\begin{array}{c}0.01 \\
(0.02)\end{array}$ & $\begin{array}{c}0.18^{* * *} \\
(0.06)\end{array}$ \\
\hline WifeEarnsMore*East & \multicolumn{5}{|c|}{$\begin{array}{c}-0.14^{* * *} \\
(0.04)\end{array}$} & $\begin{array}{c}-0.18^{* * *} \\
(0.05)\end{array}$ \\
\hline East & \multicolumn{6}{|c|}{$\begin{array}{c}-0.67^{* * *} \\
(0.07)\end{array}$} \\
\hline Individual fixed-effects & No & No & No & Yes & Yes & Yes \\
\hline Individuals & & & & 4128 & 1976 & 6104 \\
\hline Observations & 22091 & 12114 & 34205 & 22091 & 12114 & 34205 \\
\hline Panel $B$ & \multicolumn{6}{|c|}{ Dep. Var.: Divorced within a 5-year time horizon (1=Yes) } \\
\hline WifeEarnsMore & $\begin{array}{c}0.01 \\
(0.02)\end{array}$ & $\begin{array}{c}0.00 \\
(0.01)\end{array}$ & $\begin{array}{c}0.02 \\
(0.02)\end{array}$ & $\begin{array}{l}0.03^{*} \\
(0.02)\end{array}$ & $\begin{array}{c}-0.01^{* *} \\
(0.01)\end{array}$ & $\begin{array}{l}0.03^{*} \\
(0.02)\end{array}$ \\
\hline WifeEarnsMore*East & & & $\begin{array}{l}-0.01 \\
(0.03)\end{array}$ & & & $\begin{array}{c}-0.05^{* *} \\
(0.02)\end{array}$ \\
\hline East & & & $\begin{array}{l}-0.01 \\
(0.04)\end{array}$ & & & \\
\hline Couple fixed-effects & No & No & No & Yes & Yes & Yes \\
\hline Couples & & & & 1900 & 882 & 2782 \\
\hline Observations & 9054 & 4919 & 13973 & 9054 & 4919 & 13973 \\
\hline Panel $C$ & \multicolumn{6}{|c|}{ Dep. Var.: Woman Out of the labor market in $T+1$ (1=Yes) } \\
\hline WifeEarnsMore & $\begin{array}{c}0.02^{* * *} \\
(0.00)\end{array}$ & $\begin{array}{c}0.00 \\
(0.00)\end{array}$ & $\begin{array}{c}0.02^{* * *} \\
(0.00)\end{array}$ & $\begin{array}{c}0.01 \\
(0.00)\end{array}$ & $\begin{array}{l}-0.00 \\
(0.00)\end{array}$ & $\begin{array}{c}0.01 \\
(0.00)\end{array}$ \\
\hline WifeEarnsMore*East & & & $\begin{array}{c}-0.02^{* * *} \\
(0.00)\end{array}$ & & & $\begin{array}{l}-0.01 \\
(0.01)\end{array}$ \\
\hline East & & & $\begin{array}{c}-0.03^{* * *} \\
(0.01)\end{array}$ & & & \\
\hline $\begin{array}{l}\text { Individual fixed-effects } \\
\text { Individuals }\end{array}$ & No & No & No & $\begin{array}{c}\text { Yes } \\
3255\end{array}$ & $\begin{array}{c}\text { Yes } \\
1510\end{array}$ & $\begin{array}{l}\text { Yes } \\
4765\end{array}$ \\
\hline Observations & 22159 & 12115 & 34274 & 22159 & 12115 & 34274 \\
\hline
\end{tabular}

Notes: ${ }^{*} \mathrm{p}<0.1,{ }^{*} \mathrm{p}<0.05,{ }^{* * *} \mathrm{p}<0.01$. The data comes from the German SocioEconomic Panel using all the waves from 1991 until 2012. The sample contains only dual earner married couples. Standard errors clustered at the Land level $(n=16)$ level are given in parentheses. East is a dummy equals to 1 when both spouses lived in the former GDR before 1989. Controls include log of household income, respondent and partners' age and age squared, respondent and partner's education level, a dummy controlling for the presence of children, year fixed-effects, Land fixed-effects and individual fixedeffects (columns 4,5 and 6). Panel $\mathrm{A}$ and $\mathrm{C}$ further control for relative income and Panel A and B for respondent and partner's log of individual income. 
Table E13: Consequences of Violating the Male Breadwinner Norm. Clustering at the District Level

\begin{tabular}{|c|c|c|c|c|c|c|}
\hline & $\begin{array}{l}\text { West } \\
(1) \\
\end{array}$ & $\begin{array}{c}\text { East } \\
(2) \\
\end{array}$ & $\begin{array}{l}\text { All } \\
(3) \\
\end{array}$ & $\begin{array}{c}\text { West } \\
(4) \\
\end{array}$ & $\begin{array}{c}\text { East } \\
(5) \\
\end{array}$ & $\begin{array}{l}\text { All } \\
(6) \\
\end{array}$ \\
\hline Panel $A$ & \multicolumn{6}{|c|}{ Dep. Var.: Female Housework Time (Hours per day) } \\
\hline Wife Earns More & $\begin{array}{c}0.1^{*} \\
(0.05)\end{array}$ & $\begin{array}{l}-0.02 \\
(0.04)\end{array}$ & $\begin{array}{c}0.12^{* *} \\
(0.05)\end{array}$ & $\begin{array}{c}0.17^{* * *} \\
(0.04)\end{array}$ & $\begin{array}{c}0.01 \\
(0.03)\end{array}$ & $\begin{array}{c}0.18^{* * *} \\
(0.04)\end{array}$ \\
\hline WifeEarnsMore*East & & & $\begin{array}{c}-0.14^{* *} \\
(0.06)\end{array}$ & & & $\begin{array}{c}-0.18^{* * *} \\
(0.05)\end{array}$ \\
\hline East & & & $\begin{array}{c}-0.67^{* * *} \\
(0.10)\end{array}$ & & & \\
\hline Individual fixed-effects & No & No & No & Yes & Yes & Yes \\
\hline Individuals & & & & 4128 & 1976 & 6104 \\
\hline Observations & 22091 & 12114 & 34559 & 22091 & 12114 & 34205 \\
\hline Panel $B$ & \multicolumn{6}{|c|}{ Dep. Var.: Divorced within a 5-year time horizon (1=Yes) } \\
\hline WifeEarnsMore & $\begin{array}{c}0.01 \\
(0.03)\end{array}$ & $\begin{array}{c}0.00 \\
(0.01)\end{array}$ & $\begin{array}{c}0.02 \\
(0.02)\end{array}$ & $\begin{array}{l}0.03^{*} \\
(0.02)\end{array}$ & $\begin{array}{l}-0.01 \\
(0.01)\end{array}$ & $\begin{array}{l}0.03^{*} \\
(0.02)\end{array}$ \\
\hline WifeEarnsMore*East & & & $\begin{array}{l}-0.01 \\
(0.02)\end{array}$ & & & $\begin{array}{c}-0.05^{* *} \\
(0.02)\end{array}$ \\
\hline East & & & $\begin{array}{l}-0.01 \\
(0.03)\end{array}$ & & & \\
\hline Couple fixed-effects & No & No & No & Yes & Yes & Yes \\
\hline Couples & & & & 1900 & 882 & 2782 \\
\hline Observations & 9054 & 4919 & 13973 & 9054 & 4919 & 13973 \\
\hline Panel $C$ & \multicolumn{6}{|c|}{ Dep. Var.: Woman Out of the labor market in $T+1(1=Y e s)$} \\
\hline WifeEarnsMore & $\begin{array}{c}0.02^{* * * *} \\
(0.00)\end{array}$ & $\begin{array}{c}0.00 \\
(0.00)\end{array}$ & $\begin{array}{c}0.02^{* * * *} \\
(0.00)\end{array}$ & $\begin{array}{l}0.01^{*} \\
(0.00)\end{array}$ & $\begin{array}{l}-0.00 \\
(0.00)\end{array}$ & $\begin{array}{l}0.01^{*} \\
(0.00)\end{array}$ \\
\hline WifeEarnsMore*East & & & $\begin{array}{c}-0.02^{* * *} \\
(0.00)\end{array}$ & & & $\begin{array}{l}-0.01 \\
(0.01)\end{array}$ \\
\hline East & & & $\begin{array}{c}-0.03^{* * *} \\
(0.01)\end{array}$ & & & \\
\hline Individual fixed-effects & No & No & No & Yes & Yes & Yes \\
\hline Individuals & & & & 3255 & 1510 & 4765 \\
\hline Observations & 22159 & 12115 & 34274 & 22159 & 12115 & 34274 \\
\hline
\end{tabular}

Notes: ${ }^{*} \mathrm{p}<0.1,{ }^{* *} \mathrm{p}<0.05,{ }^{* * *} \mathrm{p}<0.01$. The data comes from the German SocioEconomic Panel using all the waves from 1991 until 2012. The sample contains only dual earner married couples. Standard errors clustered at the district level $(n=404)$ are given in parentheses. East is a dummy equals to 1 when both spouses lived in the former GDR before 1989. Controls include log of household income, respondent and partners' age and age squared, respondent and partner's education level, a dummy controlling for the presence of children, year fixed-effects, Land fixed-effects and individual fixedeffects (columns 4,5 and 6). Panel $\mathrm{A}$ and $\mathrm{C}$ further control for relative income and Panel A and B for respondent and partner's log of individual income. 


\section{E.8 Accounting for the Variation in Paid-Work Time}

This section investigates the role of paid-work time variations on doing gender behaviors. It shows that our results hold even when the female relative and absolute paid-work time remain stable or vary marginally.

Figure E1 presents the main estimates of the relationship between women's housework time and relative income restricting the sample to couples where the variation of relative female paid-work time between two successive periods is within the bandwidths on the X-axis (0, 1 p.p., 2 p.p.,...). ${ }^{18}$ As we can see, the coefficient related to WifeEarnsMore is essentially stable at around 0.2-0.25 and always offset by the one associated with WifeEarnsMore * East, which is negative. In terms of precision, the results become statistically significant at the $5 \%$ level from a 2 p.p. variation of female relative paidwork time. Below this threshold, the coefficients are less precisely estimated but similar in terms of magnitude.

Figure E2 replicates the same exercise using the variation of absolute female paid-work time. It thus restricts the sample to couples where the number of paid-work time of the wife is within a set of bandwith (stable, 1 hour, 2 hours, ...). ${ }^{19}$ As we can see, the results hold across the entire set of bandwidths with a magnitude of about 0.25 for the coefficient related to WifeEarnsMore, always offset by the one on WifeEarnsMore * East.

\footnotetext{
${ }^{18}$ For instance, if $\mathrm{x}=2$, it means that the difference of female relative paid-work time (Female PaidWorkTime/Female+Male PaidWorkTime) between 2 successive periods must be within the $[-0.02 ; 0.02]$ interval. Assuming that the share was initially at $50 \%$, it means that the sample is restricted to couples where the wife's relative paid-work time will remain between $48 \%$ and $52 \%$.

${ }^{19}$ For instance, if $\mathrm{x}=2$, it means that the difference of female paid work time between 2 successive periods must be within the $[-2 ; 2]$ interval. Assuming that the wife was initially working 40 hours per week, it means that the sample is restricted to couples where the wife's absolute paid-work time will remain between 38 and 42 hours.
} 
Figure E1: Woman's Housework Time and Relative Income depending on the Variation of Relative Female Paid-Work Time.

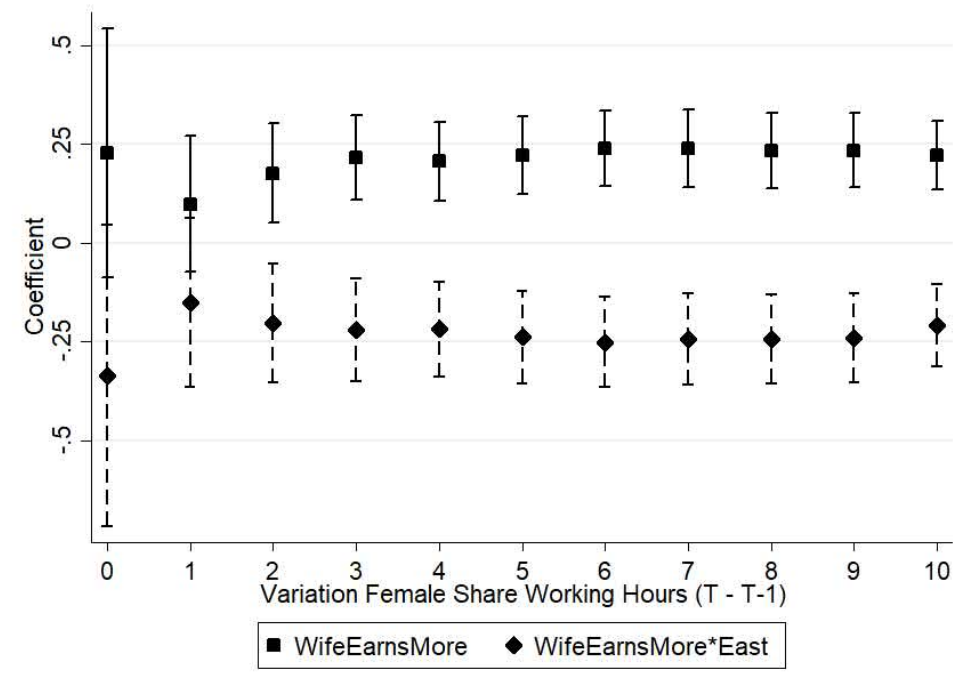

Notes: The data comes from the German Socio-Economic Panel using all the waves from 1991 until 2012. Each dot represents the coefficient from the main regression using female housework time as an outcome variable. The $\mathrm{x}$-axis represents the bandwidth of the variation of the relative female paid-work time within 2 successive years. Square dots represent the coefficient related to WifeEarnsMore (solid confidence intervals are represented at the $95 \%$ level) and diamond dots represent the coefficient related to WifeEarnsMore * East (dashed confidence intervals are represented at the $95 \%$ level). Standard errors clustered at the individual level are given in parentheses. Controls include relative income between spouses, $\log$ of household income, log of woman's income and log of man's income, respondent and partners' age and age squared, respondent and partner's education level, a dummy controlling for the presence of children, year fixed-effects, Land fixed-effects and individual fixed-effects. 
Figure E2: Woman's Housework Time and Relative Income depending on the Variation of Absolute Female Paid-Work Time.

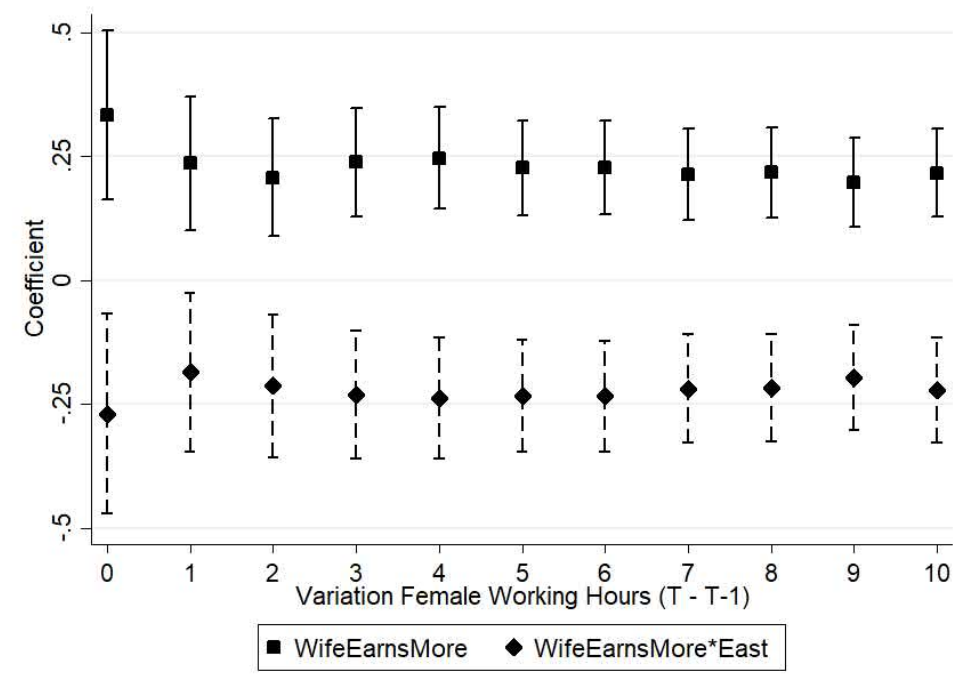

Notes: The data comes from the German Socio-Economic Panel using all the waves from 1991 until 2012. Each dot represents the coefficient from the main regression using female housework time as an outcome variable. The $\mathrm{x}$-axis represents the bandwidth of the variation of the absolute female paid-work time within 2 successive years. Square dots represent the coefficient related to WifeEarnsMore (solid confidence intervals are represented at the $95 \%$ level) and diamond dots represent the coefficient related to WifeEarnsMore * East (dashed confidence intervals are represented at the $95 \%$ level). Standard errors clustered at the individual level are given in parentheses. Controls include relative income between spouses, $\log$ of household income, log of woman's income and log of man's income, respondent and partners' age and age squared, respondent and partner's education level, a dummy controlling for the presence of children, year fixed-effects, Land fixed-effects and individual fixed-effects. 


\section{E.9 Dropping the First Years Post-Reunification}

Table E14: Woman's Housework Time and Relative Income. Dropping the First Years Post-Reunification

\begin{tabular}{|c|c|c|c|c|c|}
\hline & \multicolumn{5}{|c|}{ Dependent Variable: Woman's Housework Time } \\
\hline & $\begin{array}{c}1992- \\
(1)\end{array}$ & $\begin{array}{c}1993- \\
(2)\end{array}$ & $\begin{array}{c}1994- \\
(3)\end{array}$ & $\begin{array}{c}1995- \\
(4)\end{array}$ & $\begin{array}{c}1996- \\
(5)\end{array}$ \\
\hline WifeEarnsMore & $\begin{array}{c}0.19^{* * *} \\
(0.04)\end{array}$ & $\begin{array}{c}0.19^{* * *} \\
(0.04)\end{array}$ & $\begin{array}{c}0.19^{* * *} \\
(0.04)\end{array}$ & $\begin{array}{c}0.18^{* * *} \\
(0.04)\end{array}$ & $\begin{array}{c}0.17^{* * * *} \\
(0.04)\end{array}$ \\
\hline WifeEarnsMore*East & $\begin{array}{c}-0.20^{* * *} \\
(0.05)\end{array}$ & $\begin{array}{c}-0.20^{* * *} \\
(0.05)\end{array}$ & $\begin{array}{c}-0.19^{* * *} \\
(0.05)\end{array}$ & $\begin{array}{c}-0.18^{* * *} \\
(0.06)\end{array}$ & $\begin{array}{c}-0.16^{* * *} \\
(0.06)\end{array}$ \\
\hline Individual fixed-effects & Yes & Yes & Yes & Yes & Yes \\
\hline Individuals & 5911 & 5744 & 5605 & 5504 & 5393 \\
\hline Observations & 32843 & 31605 & 30401 & 29265 & 28130 \\
\hline
\end{tabular}

Notes: ${ }^{*} \mathrm{p}<0.1,{ }^{* *} \mathrm{p}<0.05,{ }^{* * *} \mathrm{p}<0.01$. The data comes from the German Socio-Economic Panel using all the waves from 1991 until 2012. Standard errors clustered at the individual level are given in parentheses. East is a dummy equals to 1 when both spouses lived in the former GDR before 1989 . Controls include relative income between spouses, log of household income, $\log$ of woman's income and log of man's income, respondent and partners' age and age squared, respondent and partner's education level, a dummy controlling for the presence of children, year fixed-effects, Land fixed-effects and individual fixed-effects. 


\section{E.10 Alternative Mechanisms - Historical Differences in Unobservables}

Table E15 shows that there is a sharp jump in the female share of household income at the border between East and West Germany.

Table E15: Regression discontinuity of the Female Income Share in Household Income depending on the Distance to the East/West Border

\begin{tabular}{|c|c|c|c|c|}
\hline & $\begin{array}{c}50 \mathrm{~km} \\
(1)\end{array}$ & $\begin{array}{c}100 \mathrm{~km} \\
(2)\end{array}$ & $\begin{array}{c}150 \mathrm{~km} \\
(3)\end{array}$ & $\begin{array}{c}200 \mathrm{~km} \\
(4)\end{array}$ \\
\hline \multirow[b]{2}{*}{ East } & \multicolumn{4}{|c|}{ Model A: Local linear polynomial } \\
\hline & $\begin{array}{l}0.104^{* * *} \\
(0.0 .022)\end{array}$ & $\begin{array}{c}0.115^{* * *} \\
(0.016)\end{array}$ & $\begin{array}{c}0.122^{* * *} \\
(0.013)\end{array}$ & $\begin{array}{c}0.117^{* * *} \\
(0.012)\end{array}$ \\
\hline Observations & 7684 & 15122 & 25185 & 35406 \\
\hline & \multicolumn{4}{|c|}{ Model B: Third order polynomial } \\
\hline East & $\begin{array}{c}0.102^{* * *} \\
(0.037)\end{array}$ & $\begin{array}{c}0.101^{* * *} \\
(0.02)\end{array}$ & $\begin{array}{c}0.119^{* * *} \\
(0.017)\end{array}$ & $\begin{array}{c}0.124^{* * *} \\
(0.015)\end{array}$ \\
\hline \multirow[t]{2}{*}{ Observations } & 7684 & 15122 & 25185 & 35406 \\
\hline & \multicolumn{4}{|c|}{ Model C: Local linear polynomial with control } \\
\hline East & $\begin{array}{l}0.1 * * * \\
(0.025)\end{array}$ & $\begin{array}{c}0.101 * * * \\
(0.016)\end{array}$ & $\begin{array}{c}0.108^{* * *} \\
(0.014)\end{array}$ & $\begin{array}{c}0.099 * * * \\
(0.011)\end{array}$ \\
\hline Observations & 7684 & 15122 & 25185 & 35406 \\
\hline
\end{tabular}

Notes: ${ }^{*} \mathrm{p}<0.1,{ }^{* *} \mathrm{p}<0.05,{ }^{* * *} \mathrm{p}<0.01$. The data comes from the German Socio-Economic Panel using all the waves from 1991 until 2012. The sample contains only dual earner married couples. Standard errors clustered at the household level are given in parentheses. East is a dummy equals to 1 when the household is located in East Germany. Model A includes a local linear polynomial in distance from the border and model $\mathrm{B}$ includes a third order polynomial in distance from the border. Model C includes the following controls: $\log$ of the household income, respondent's and partner's age, age squared and educational level and a dummy controlling for the presence of children. Observations are weighted by proximity to the border using a triangular kernel.

We also replicated our main result concerning the relationship between women's housework time and WifeEarnsMore in the vicinity of the East/West Border. This provides supporting evidence that our results are not driven by historical differences in unobservables or by other structural differences.

Table E16 displays regression estimates using four different bandwidths. Doing gender is taking place on the western side of the border. West German women increase the time spent on housework by 0.23-0.31 hours per day while East German women do not. As we 
move towards the border, the sample size and the precision of the estimations diminish. At the $50 \mathrm{~km}$ threshold, the p-value is 0.11 for the coefficient related to WifeEarnsMore* East and its magnitude is in line with the coefficients at different bandwidths.

In the same vein, Figure E3 displays the estimates at every $10 \mathrm{~km}$ bin from 50 to 200 $\mathrm{km}$ around the border. Importantly, the coefficients remain stable in magnitude across the territory while historical and persisting differences are expected to grow as we move away from the East/West border. This suggests that our results are driven by the lasting cultural consequences of the division of Germany, rather than by some structural features of these territories.

Table E16: Woman's Housework Time and Relative Income. Restricting the Sample Around the East/West Border

\begin{tabular}{lcccc}
\hline \multicolumn{5}{c}{ Dependent Variable: Woman's Housework Time } \\
\hline & $50 \mathrm{~km}$ & $100 \mathrm{~km}$ & $150 \mathrm{~km}$ & $200 \mathrm{~km}$ \\
& $(1)$ & $(2)$ & $(3)$ & $(4)$ \\
\hline \hline WifeEarnsMore & $0.23^{* *}$ & $0.31^{* * *}$ & $0.26^{* * *}$ & $0.23^{* * *}$ \\
& $(0.11)$ & $(0.09)$ & $(0.07)$ & $(0.05)$ \\
WifeEarnsMore*East & -0.19 & $-0.27^{* * *}$ & $-0.24^{* * *}$ & $-0.23^{* * *}$ \\
& $(0.12)$ & $(0.1)$ & $(0.07)$ & $(0.06)$ \\
Individual fixed-effects & Yes & Yes & Yes & Yes \\
Individuals & 1093 & 2054 & 3373 & 4646 \\
Observations & 6222 & 11824 & 19612 & 26378 \\
\hline
\end{tabular}

Notes: $* \mathrm{p}<0.1, * * \mathrm{p}<0.05, * * * \mathrm{p}<0.01$. The data comes from the German Socio-Economic Panel using all the waves from 1991 until 2012. Standard errors clustered at the individual level are given in parentheses. East is a dummy equals to 1 if the household lives in East Germany. Controls include relative income between spouses, log of household income, log of woman's income and log of man's income, respondent and partners' age and age squared, respondent and partner's education level, a dummy controlling for the presence of children, year fixed-effects, Land fixed-effects and individual fixed-effects. 
Figure E3: Woman's Housework Time and Relative Income around the East/West Border. Different Bandwidths

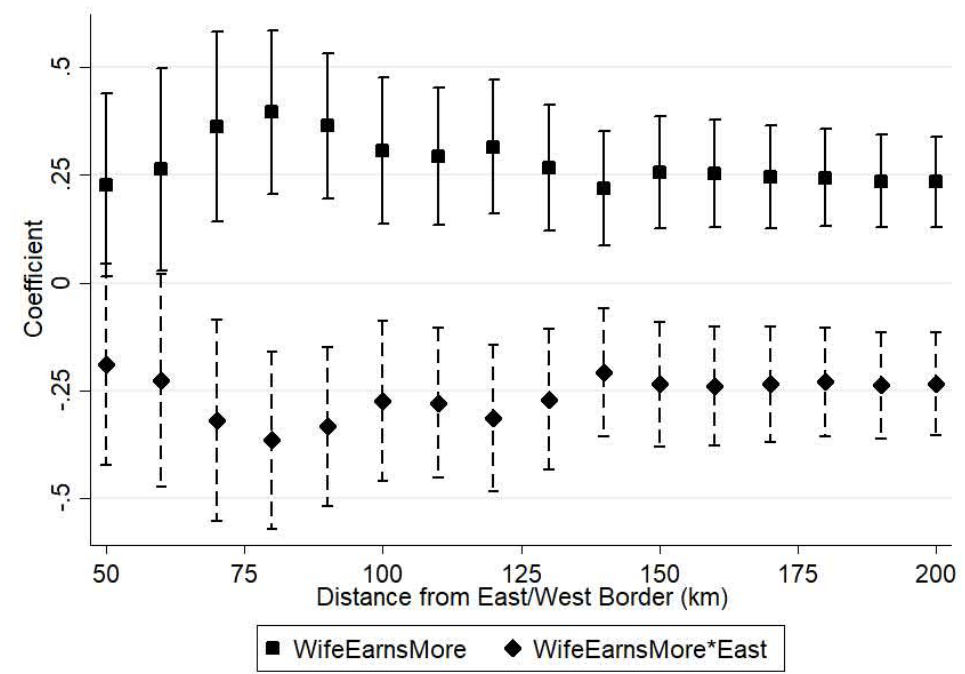

Notes: The data comes from the German Socio-Economic Panel using all the waves from 1991 until 2012. Square dots represent the coefficient related to WifeEarnsMore (solid confidence intervals are represented at the $95 \%$ level) and diamond dots represent the coefficient related to WifeEarnsMore * East (dashed confidence intervals are represented at the 95\% level). Standard errors clustered at the individual level are given in parentheses. Controls include relative income between spouses, $\log$ of household income, log of woman's income and log of man's income, respondent and partners' age and age squared, respondent and partner's education level, a dummy controlling for the presence of children, year fixed-effects, Land fixed-effects and individual fixed-effects. 


\section{E.11 Alternative Mechanisms- Do the East/West Income Level Differences Matter?}

This section investigates the potential role of household income level in explaining the occurence of doing gender behaviors. The suspicion is that East German couples are obviously poorer, which could explain why they do not engage in doing gender behaviors. To investigate, we exploit the heterogeneity within West Germany to contrast the behavior of households depending on their income. We use two measures: one regional measure based on the average household income of the Land (macro definition) and one individual measure based on the relative position of a household in the distribution of household income across the entire West Germany (micro definition).

Table E17 provides descriptive statistics on the income of households in the three categories: within West Germany above the median, within West Germany below the median and in East Germany. In Panel A, using a micro measure, we see that the bottom half of the distribution of West German couples earn on average 2418 euros, whereas the upper half earns 4879 euros. East German households earn on average 2661 euros. Thus, East German households are on average in between the average of below and above the median household income within West Germany. In Panel B, using a regional (macro) measure of household income, we see that East German couples lag behind the couples living in the poorest West German Länder and we obtain less heterogeneity within West Germany.

Table E18 replicates the main result contrasting the behavior of West German households living in poor households in columns 1 to 3 (and alternatively poor Länder in columns 4 to 6) against those living in households (Länder) whose income is above the median. We see that in both groups, West German women keep increasing their housework time when they earn more than their husband. In column 1 to 3, which uses an individual definition displaying larger levels of heterogeneity, there is very little difference among the two groups. 
Table E1\%: Descriptive Statistics on the Income Level

\begin{tabular}{llll}
\hline & \multicolumn{2}{c}{ West Germany } & East Germany \\
& $\begin{array}{l}\text { Above } \\
\text { Median } \\
(1)\end{array}$ & $\begin{array}{l}\text { Below } \\
\text { Median } \\
(2)\end{array}$ & $(3)$ \\
\hline Panel A: Individual (Micro) Level & & & \\
Household Income & 4879 & 2418 & 2661 \\
& $(2874)$ & $(490)$ & $(1234)$ \\
\hline Panel B: Regional (Macro) Level & & & \\
Household Income & 3625 & 3232 & 2568 \\
& $(214)$ & $(150)$ & $(97)$ \\
\hline
\end{tabular}

Notes: ${ }^{*} \mathrm{p}<0.1,{ }^{* *} \mathrm{p}<0.05,{ }^{* * *} \mathrm{p}<0.01$. The data comes from the German Socio-Economic Panel using all the waves from 1991 until 2012. This table displays the mean and standard deviations (in parentheses) of household incomes based on the definitions at the individual (micro) level or at the regional (macro) level.

Table E18: Housework Time and Relative Income Depending on the Household Income Level

\begin{tabular}{|c|c|c|c|c|c|c|}
\hline \multicolumn{7}{|c|}{ Dependent variable: Woman's Housework Time (hours per day) } \\
\hline & $\begin{array}{c}\text { Referenc } \\
(1)\end{array}$ & $\begin{array}{c}e: \text { Individ } \\
(2) \\
\end{array}$ & $\begin{array}{c}\text { Lal Level } \\
(3) \\
\end{array}$ & $\begin{array}{c}\text { Reference } \\
(4) \\
\end{array}$ & $\begin{array}{c}\text { e: Region } \\
(5) \\
\end{array}$ & $\begin{array}{c}\text { al Level } \\
(6) \\
\end{array}$ \\
\hline WifeEarnsMore & $\begin{array}{c}0.18^{* * *} \\
(0.06)\end{array}$ & $\begin{array}{c}0.19 * * * \\
(0.07)\end{array}$ & $\begin{array}{c}0.18^{* * *} \\
(0.05)\end{array}$ & $\begin{array}{c}0.18 * * * \\
(0.06)\end{array}$ & $\begin{array}{c}0.16^{* *} \\
(0.07)\end{array}$ & $\begin{array}{c}0.16^{* * *} \\
(0.06)\end{array}$ \\
\hline WifeEarnsMore*Below Median & & & $\begin{array}{l}-0.02 \\
(0.07)\end{array}$ & & & \\
\hline WifeEarnsMore*Below Median & & & & & & $\begin{array}{c}0.04 \\
(0.09)\end{array}$ \\
\hline Sample & $\begin{array}{l}\text { Above } \\
\text { Median }\end{array}$ & $\begin{array}{l}\text { Below } \\
\text { Median }\end{array}$ & All & $\begin{array}{l}\text { Above } \\
\text { Median }\end{array}$ & $\begin{array}{l}\text { Below } \\
\text { Median }\end{array}$ & All \\
\hline Couples & 2583 & 2643 & 4010 & 2235 & 1807 & 4010 \\
\hline Observations & 10807 & 10652 & 21459 & 11804 & 9655 & 21459 \\
\hline
\end{tabular}

Notes: $* \mathrm{p}<0.1,{ }^{*} \mathrm{p}<0.05, * * * \mathrm{p}<0.01$. The data comes from the German Socio-Economic Panel using all the waves from 1991 until 2012. The sample contains only West German dual earner married couples. The sample is restricted to households above the median in columns 1 and 4 , below the median in columns 2 and 5 and includes all the households in columns 3 and 6 . Standard errors clustered at the individual level are given in parentheses. Controls: relative income between spouses, log of household income, respondent and partner's log of individual income, respondent and partner's age and age squared, respondent and partner's education level, a dummy controlling for the presence of children, year fixedeffects, Land fixed-effects and individual fixed-effects. 


\section{E.12 Alternative Mechanisms - Do the East/West Male Hourly Wages Dif- ferences Matter?}

In this section, we replicate the same exercise as in the previous section using the male hourly wage. The suspicion is that in a context of low male hourly wage, women may have a larger household bargaining power and refuse to engage in doing gender behaviors. This could potentially explain why these behaviors are not observed in East Germany. To investigate this channel, we exploit the heterogeneity within West Germany to contrast the behavior of households depending on the male hourly wage. We use two measures: one regional measure based on the average male hourly wage of the Land (macro definition) and one individual measure based on the relative position of one household in the distribution of male hourly wages across the entire West Germany (micro definition).

Table E19 provides descriptive statistics about male and female hourly wages as well as the gender gap in hourly wages (male - female) of households in the three categories: within West Germany above the median, within West Germany below the median, and in East Germany. In Panel A, we see that within the bottom half of the distribution of West Germans, the male hourly wage is about 8.4 euros, whereas in the upper half, it is about 17.7 euros. East German men are close but below the bottom half of West German men, as they earn on average 7.84 euros per hour. In terms of gender gap between men and women, in the upper half of West German couples, we observe a gender gap of about 8.1 euros per hour whereas it is about 0.8 euros for the bottom half. East German households are in between with a gender gap of about 1.05 euros per hour. In Panel B, using a regional (macro) measure of male hourly wage, we obtain much less variation. West German men living in Länder where the male hourly wage is above the median earn on average 13.45 euros per hour, whereas those living in the bottom half earn about 12.17 euros per hour.

Table E20 replicates the main result contrasting the behavior of West Germans living in households where the male hourly wage is below the Western median against those living in households (Länder) whose male hourly wages is above the median. We see that in both groups, West German women spend more time on housework when they earn more than their husband. In column 1 to 3, which uses the micro definition, with a higher level of heterogeneity, there is little difference between the two types of households. Point estimates are slightly lower in households whose male hourly wage is below the median but the estimation coefficients remain unambiguously positive and significant at the $1 \%$ level. In columns 4 to 6 , which use the macro definition, the pattern is similar. 
Table E19: Descriptive Statistics on Hourly Wages

\begin{tabular}{llll}
\hline & \multicolumn{2}{c}{ West Germany } & East Germany \\
& $\begin{array}{l}\text { Above } \\
\text { Median } \\
(1)\end{array}$ & $\begin{array}{l}\text { Below } \\
\text { Median } \\
(2)\end{array}$ & $(3)$ \\
\hline Panel A: Individual (Micro) Level & & & \\
Male Hourly Wage & 17.7 & 8.41 & 7.84 \\
& $(10.09)$ & $(2.09)$ & $(4.99)$ \\
Female Hourly Wage & 9.6 & 7.6 & 6.79 \\
& $(6.27)$ & $(5.2)$ & $(4.11)$ \\
Gender Gap Hourly Wage & 8.1 & .81 & 1.05 \\
& $(11.1)$ & $(5.63)$ & $(5.52)$ \\
\hline Panel B: Regional (Macro) Level & & & \\
Male Hourly Wage & 13.45 & 12.17 & 7.72 \\
& $(1.04)$ & $(0.37)$ & $(0.45)$ \\
Female Hourly Wage & 8.97 & 8.21 & 6.76 \\
Gender Gap Hourly Wage & $(0.82)$ & $(0.33)$ & $(0.32)$ \\
& 4.36 & 3.73 & 0.97 \\
& $(2.07)$ & $(0.19)$ & $(0.22)$ \\
\hline
\end{tabular}

Notes: ${ }^{*} \mathrm{p}<0.1,{ }^{* *} \mathrm{p}<0.05,{ }^{* * *} \mathrm{p}<0.01$. The data comes from the German Socio-Economic Panel using all the waves from 1991 until 2012. This table displays the mean and standard deviations (in parentheses) of household incomes based on the definitions at the individual level or at the regional level. 
Table E20: Housework Time and Relative Income Depending on the Male Hourly Wage Level

\begin{tabular}{|c|c|c|c|c|c|c|}
\hline \multicolumn{7}{|c|}{ Dependent variable: Woman's Housework Time (Hours per Day) } \\
\hline & $\begin{array}{c}\text { Reference } \\
(1)\end{array}$ & $\begin{array}{c}\text { e: Individ } \\
(2) \\
\end{array}$ & $\begin{array}{c}\text { ual Level } \\
(3)\end{array}$ & $\begin{array}{l}\text { Reference } \\
(4)\end{array}$ & $\begin{array}{c}e: \text { Region } \\
(5)\end{array}$ & $\begin{array}{c}\text { al Level } \\
(6) \\
\end{array}$ \\
\hline WifeEarnsMore & $\begin{array}{c}0.25^{* * *} \\
(0.08)\end{array}$ & $\begin{array}{c}0.16^{* * *} \\
(0.06)\end{array}$ & $\begin{array}{c}0.24^{* * *} \\
(0.07)\end{array}$ & $\begin{array}{c}0.19 * * * \\
(0.07)\end{array}$ & $\begin{array}{c}0.18^{* * *} \\
(0.06)\end{array}$ & $\begin{array}{c}0.18^{* * * *} \\
(0.07)\end{array}$ \\
\hline WifeEarnsMore*Below Median & & & $\begin{array}{l}-0.06 \\
(0.08)\end{array}$ & & & \\
\hline WifeEarnsMore*Below Median & & & & & & $\begin{array}{c}0.02 \\
(0.09)\end{array}$ \\
\hline Sample & $\begin{array}{l}\text { Above } \\
\text { Median }\end{array}$ & $\begin{array}{l}\text { Below } \\
\text { Median }\end{array}$ & All & $\begin{array}{l}\text { Above } \\
\text { Median }\end{array}$ & $\begin{array}{l}\text { Below } \\
\text { Median }\end{array}$ & All \\
\hline $\begin{array}{l}\text { Couples } \\
\text { Observations }\end{array}$ & $\begin{array}{c}2570 \\
10514\end{array}$ & $\begin{array}{c}2605 \\
10335\end{array}$ & $\begin{array}{c}3981 \\
20849\end{array}$ & $\begin{array}{l}1940 \\
9824\end{array}$ & $\begin{array}{c}2072 \\
11025\end{array}$ & $\begin{array}{c}3981 \\
20849\end{array}$ \\
\hline
\end{tabular}

Notes: ${ }^{*} \mathrm{p}<0.1,{ }^{*} \mathrm{p}<0.05, * * * \mathrm{p}<0.01$. The data comes from the German Socio-Economic Panel using all the waves from 1991 until 2012. The sample contains only West German dual earner married couples. The sample is restricted to households above the median in columns 1 and 4 , below the median in columns 2 and 5 and includes all the households in columns 3 and 6 . Standard errors clustered at the individual level are given in parentheses. Controls: relative income between spouses, log of household income, respondent and partner's log of individual income, respondent and partner's age and age squared, respondent and partner's education level, a dummy controlling for the presence of children, year fixedeffects, Land fixed-effects and individual fixed-effects.

\section{E.13 Alternative Mechanisms- Do the East/West Wage Dispersion Differ- ences Matter?}

This section investigates the potential role of the dispersion of wages in explaining the occurence of doing gender. As explained in Section 5.2, we exploit the heterogeneity within West Germany and contrast the behavior of couples in places where the dispersion of wages is high versus low.

Table E21 provides descriptive statistics about income dispersion. We use two of the most commonly used measures: Gini index and variance of logs. The two measures deliver a similar picture. In West German Länder, the Gini index of the female income, male income and household income in Länder where it is above the median is of respectively $0.4,0.34$ and 0.28 whereas it is of $0.37,0.26$ and 0.23 in places where it is below the median. The dispersion level of the male income and household income (but not female income) in East German Länder is in between the average of the dispersion found in Western Länder above and below the median. In Panel B, using the variance of log as a 
measure of dispersion, we obtain a similar picture.

In Table E22, E23 and E24, we exploit the heterogeneity in the dispersion level of respectively the household income, the male income and the female income, within West Germany. We contrast the behavior of households living in high dispersion versus low dispersion Western Länder (compared to the median). The three tables yield a similar picture: whether the dispersion level is high or low (in which case it is similar to Eastern Länder), West German woman keep increasing the time spent on housework when they earn more than their husband. As such, this doing gender behavior does not seem to be driven by the degree of income dispersion.

Table E21: Descriptive Statistics on the Income Dispersion Level

\begin{tabular}{llll}
\hline & \multicolumn{2}{c}{ West Germany } & East Germany \\
& $\begin{array}{l}\text { Above } \\
\text { Median } \\
(1)\end{array}$ & $\begin{array}{l}\text { Melow } \\
\text { Median } \\
(2)\end{array}$ & $(3)$ \\
\hline \hline Panel A: Gini Index & & & \\
Income Woman & 0.4 & 0.37 & 0.3 \\
Income Man & 0.34 & 0.26 & 0.29 \\
Household Income & 0.28 & 0.23 & 0.24 \\
\hline Panel B: Variance of Log & & & \\
Income Woman & 0.63 & 0.5 & 0.37 \\
Income Man & 0.22 & 0.16 & 0.19 \\
Household Income & 0.38 & 0.26 & 0.31 \\
\hline
\end{tabular}

Notes: ${ }^{*} \mathrm{p}<0.1,{ }^{* *} \mathrm{p}<0.05,{ }^{* * *} \mathrm{p}<0.01$. The data comes from the German SocioEconomic Panel using all the waves from 1991 until 2012. This table descriptes the measures of dispersion based on the indicator used (Gini index for Panel A and Variance of $\log$ for Panel B). 
Table E22: Housework Time and Relative Income Depending on the Regional Level of Inequality in Household Income

\begin{tabular}{|c|c|c|c|c|c|c|}
\hline \multicolumn{7}{|c|}{ Dependent variable: Woman's Housework Time (hours per day) } \\
\hline \multirow[t]{2}{*}{ Dispersion Measure } & \multicolumn{3}{|c|}{ Gini } & \multicolumn{3}{|c|}{ Variance of Log } \\
\hline & $(1)$ & $(2)$ & $(3)$ & $(4)$ & $(5)$ & $(6)$ \\
\hline WifeEarnsMore & $\begin{array}{c}0.19^{* * *} \\
(0.06)\end{array}$ & $\begin{array}{l}0.14^{*} \\
(0.07)\end{array}$ & $\begin{array}{c}0.19^{* * *} \\
(0.06)\end{array}$ & $\begin{array}{c}0.19^{* * *} \\
(0.06)\end{array}$ & $\begin{array}{l}0.14^{*} \\
(0.07)\end{array}$ & $\begin{array}{c}0.19^{* * * *} \\
(0.06)\end{array}$ \\
\hline WifeEarnsMore*Below Median & & & & & & $\begin{array}{l}-0.05 \\
(0.09)\end{array}$ \\
\hline WifeEarnsMore*Below Median & & & $\begin{array}{l}-0.05 \\
(0.09)\end{array}$ & & & \\
\hline Sample & Above & Below & & Above & Below & \\
\hline & Median & Median & & Median & Median & \\
\hline Couples & 2112 & 1922 & 4010 & 2112 & 1922 & 4010 \\
\hline Observations & 11428 & 10031 & 21459 & 11428 & 10031 & 21459 \\
\hline
\end{tabular}

Notes: $* \mathrm{p}<0.1,{ }^{* *} \mathrm{p}<0.05,{ }^{* * *} \mathrm{p}<0.01$. The data comes from the German Socio-Economic Panel using all the waves from 1991 until 2012. The sample contains only West German dual earner married couples. The sample is restricted to households above the median in columns 1 and 4, below the median in columns 2 and 5 and includes all the households in columns 3 and 6 . Standard errors clustered at the individual level are given in parentheses. Controls: relative income between spouses, log of household income, respondent and partner's log of individual income, respondent and partner's age and age squared, respondent and partner's education level, a dummy controlling for the presence of children, year fixedeffects, Land fixed-effects and individual fixed-effects. 
Table E23: Housework Time and Relative Income Depending on the Regional Level of Inequality in Man's Income

\begin{tabular}{|c|c|c|c|c|c|c|}
\hline \multicolumn{7}{|c|}{ Dependent variable: Woman's Housework Time (hours per day) } \\
\hline \multirow[t]{2}{*}{ Dispersion Measure } & \multicolumn{3}{|c|}{ Gini } & \multicolumn{3}{|c|}{ Variance of $\log$} \\
\hline & $(1)$ & $(2)$ & $(3)$ & $(4)$ & $(5)$ & $(6)$ \\
\hline WifeEarnsMore & $\begin{array}{c}0.18^{* * *} \\
(0.06)\end{array}$ & $\begin{array}{c}0.16^{* *} \\
(0.07)\end{array}$ & $\begin{array}{c}0.16^{* * *} \\
(0.06)\end{array}$ & $\begin{array}{c}0.14^{* *} \\
(0.06)\end{array}$ & $\begin{array}{c}0.19^{* * *} \\
(0.07)\end{array}$ & $\begin{array}{c}0.14^{* *} \\
(0.06)\end{array}$ \\
\hline WifeEarnsMore*Below Median & & & & & & $\begin{array}{c}0.06 \\
(0.09)\end{array}$ \\
\hline WifeEarnsMore*Below Median & & & $\begin{array}{c}0.04 \\
(0.09)\end{array}$ & & & \\
\hline Sample & Above & Below & & Above & Below & \\
\hline & Median & Median & & Median & Median & \\
\hline Couples & 2235 & 1807 & 4010 & 1764 & 2271 & 4010 \\
\hline Observations & 11804 & 9655 & 21459 & 9603 & 11856 & 21459 \\
\hline
\end{tabular}

Notes: ${ }^{*} \mathrm{p}<0.1,{ }^{* *} \mathrm{p}<0.05,{ }^{* *} \mathrm{p}<0.01$. The data comes from the German Socio-Economic Panel using all the waves from 1991 until 2012. The sample contains only West German dual earner married couples. The sample is restricted to households above the median in columns 1 and 4 , below the median in columns 2 and 5 and includes all the households in columns 3 and 6. Standard errors clustered at the individual level are given in parentheses. Controls: relative income between spouses, $\log$ of household income, respondent and partner's log of individual income, respondent and partner's age and age squared, respondent and partner's education level, a dummy controlling for the presence of children, year fixed-effects, Land fixed-effects and individual fixed-effects. 
Table E24: Housework Time and Relative Income Depending on the Regional Level of Inequality in Female Income

\begin{tabular}{|c|c|c|c|c|c|c|}
\hline \multicolumn{7}{|c|}{ Dependent variable: Woman's Housework Time (hours per day) } \\
\hline \multirow[t]{2}{*}{ Dispersion Measure } & \multicolumn{3}{|c|}{ Gini } & \multicolumn{3}{|c|}{ Variance of Log } \\
\hline & $(1)$ & $(2)$ & $(3)$ & $(4)$ & $(5)$ & $(6)$ \\
\hline WifeEarnsMore & $\begin{array}{c}0.18^{* * *} \\
(0.06)\end{array}$ & $\begin{array}{c}0.16^{* *} \\
(0.07)\end{array}$ & $\begin{array}{c}0.16^{* * *} \\
(0.06)\end{array}$ & $\begin{array}{c}0.18^{* * *} \\
(0.06)\end{array}$ & $\begin{array}{c}0.16^{* *} \\
(0.07)\end{array}$ & $\begin{array}{c}0.16^{* * * *} \\
(0.06)\end{array}$ \\
\hline WifeEarnsMore*Below Median & & & & & & $\begin{array}{c}0.04 \\
(0.09)\end{array}$ \\
\hline WifeEarnsMore*Below Median & & & $\begin{array}{c}0.04 \\
(0.09)\end{array}$ & & & \\
\hline Sample & Above & Below & & Above & Below & \\
\hline & Median & Median & & Median & Median & \\
\hline Couples & 2235 & 1807 & 4010 & 2235 & 1807 & 4010 \\
\hline Observations & 11804 & 9655 & 21459 & 11804 & 9655 & 21459 \\
\hline
\end{tabular}

Notes: $* \mathrm{p}<0.1,{ }^{* *} \mathrm{p}<0.05,{ }^{* * *} \mathrm{p}<0.01$. The data comes from the German Socio-Economic Panel using all the waves from 1991 until 2012. The sample contains only West German dual earner married couples. SThe sample is restricted to households above the median in columns 1 and 4 , below the median in columns 2 and 5 and includes all the households in columns 3 and 6 . Standard errors clustered at the individual level are given in parentheses. Controls: relative income between spouses, log of household income, respondent and partner's log of individual income, respondent and partner's age and age squared, respondent and partner's education level, a dummy controlling for the presence of children, year fixedeffects, Land fixed-effects and individual fixed-effects.

\section{E.14 Alternative Mechanisms - Other Institutional Differences}

Table E25 provides descriptive statistics about Eastern couples who have migrated to the West. It shows that these couples seem more gender egalitarian, i.e. the woman earns a higher share of income and is more likely to earn more than her husband than in "pure" Western couples. 
Table E25: Descriptive Statistics of Couples Living in Western Länder: Movers versus Stayers

\begin{tabular}{lcccccc}
\hline & \multicolumn{2}{c}{ Lived in FRG } & \multicolumn{2}{c}{ Lived in FRG } \\
& Mean & S.D. & Mean & S.D. & Mean & S.D. \\
\hline & 0.28 & 0.17 & 0.30 & 0.16 & 0.35 & 0.16 \\
Woman's Share of Income & 0.10 & 0.31 & 0.13 & 0.33 & 0.16 & 0.36 \\
WifeEarnsMore & 2.64 & 1.50 & 2.24 & 1.36 & 2.05 & 1.21 \\
Woman's Housework Time & 0.61 & 0.72 & 0.65 & 0.65 & 0.79 & 0.76 \\
Man's Housework Time & 2.03 & 1.73 & 1.59 & 1.53 & 1.27 & 1.45 \\
Hswk Woman - Hswk Man & 26.74 & 13.21 & 28.85 & 13.72 & 33.17 & 11.53 \\
Paid Work Time Woman & 44.55 & 9.86 & 44.87 & 8.45 & 45.65 & 9.74 \\
Paid Work Time Man & 3660.03 & 2394.77 & 3651.71 & 2868.22 & 3166.87 & 1388.25 \\
Income HH (Euros) & 957.33 & 822.85 & 1017.75 & 800.17 & 1060.04 & 676.18 \\
Income Woman (Euros) & 2445.41 & 1709.47 & 2490.26 & 1527.27 & 1981.45 & 1063.96 \\
Income Man (Euros) & 8.58 & 5.39 & 8.61 & 5.52 & 7.51 & 4.29 \\
Hourly Wage Woman & 13.09 & 8.61 & 13.47 & 9.76 & 10.33 & 5.01 \\
Hourly Wage Man & 43.69 & 8.47 & 39.80 & 7.99 & 41.35 & 8.96 \\
Woman's Age & 46.33 & 8.70 & 41.96 & 8.62 & 43.45 & 9.25 \\
Man's Age & 0.68 & 0.47 & 0.65 & 0.48 & 0.61 & 0.49 \\
Kids in HH (1=YES) & 20732 & & 727 & & 896 & \\
Observations & & & & & \\
\hline
\end{tabular}

Notes: The data comes from the German Socio-Economic Panel using all the waves from 1991 until 2012. Descriptive statistics are based on the main sample: married couples with positive income. 
Although the sample of East German Migrants is small, it can still be useful to replicate the main analysis on housework and look at the point estimates. We thus replicated the main analysis on housework (which is the most robust result) restricting the sample to couples living in West German Länder and contrasting the behaviour of East German Migrants to West German natives.

The results are displayed in Table E26. Reassuringly, in our preferred specification, which includes individual fixed-effects, the coefficient related to WifeEarnsMore among East migrants (column 5) is negative. Therefore, in the interaction specification (column 6 ), the two coefficients totally offset each other (the coefficients are respectively 0.17 for WifeEarnsMore and -0.23 for WifeEarnsMore*East). Nevertheless, given the small sample size, the confidence intervals are too large and it is difficult to draw definitive conclusions. Also, the picture is different in the cross-sectional analysis where the coefficient is positive, but again not statistically significant.

Table E26: Housework Time and Relative Income - East German Migrants vs Movers within West Germany

\begin{tabular}{|c|c|c|c|c|c|c|}
\hline \multicolumn{7}{|c|}{ Dependent variable: Woman's Housework Time (hours per day) } \\
\hline & $\begin{array}{c}\text { West } \\
(1) \\
\end{array}$ & $\begin{array}{c}\text { East } \\
\text { Migr } \\
(2) \\
\end{array}$ & $\begin{array}{l}\text { All } \\
\text { (3) }\end{array}$ & $\begin{array}{c}\text { West } \\
(4) \\
\end{array}$ & $\begin{array}{c}\text { East } \\
\text { Migr } \\
(5)\end{array}$ & $\begin{array}{l}\text { All } \\
(6) \\
\end{array}$ \\
\hline WifeEarnsMore & $\begin{array}{c}0.10^{* *} \\
(0.05)\end{array}$ & $\begin{array}{c}0.29 \\
(0.19)\end{array}$ & $\begin{array}{l}0.10^{* *} \\
(0.05)\end{array}$ & $\begin{array}{c}0.17^{* * *} \\
(0.04)\end{array}$ & $\begin{array}{l}-0.11 \\
(0.23)\end{array}$ & $\begin{array}{c}0.17^{* * * *} \\
(0.04)\end{array}$ \\
\hline WifeEarnsMore*East Migr & & & $\begin{array}{c}0.02 \\
(0.15)\end{array}$ & & & $\begin{array}{l}-0.23 \\
(0.21)\end{array}$ \\
\hline East Migr & & & $\begin{array}{c}-0.54^{* * *} \\
(0.20)\end{array}$ & & & \\
\hline Individual fixed-effects & No & No & No & Yes & Yes & Yes \\
\hline Individuals & 4128 & 162 & 4290 & 4128 & 162 & 4290 \\
\hline Observations & 22091 & 896 & 22987 & 22091 & 896 & 22987 \\
\hline
\end{tabular}

Notes: ${ }^{*} \mathrm{p}<0.1,{ }^{* *} \mathrm{p}<0.05,{ }^{* * *} \mathrm{p}<0.01$. The data comes from the German Socio-Economic Panel using all the waves from 1991 until 2012. The sample contains only dual earner married couples. Standard errors clustered at the individual level are given in parentheses. EastMigr is a dummy equals to 1 when both spouses lived in the former GDR before 1989 and are now living in West Germany. Controls: relative income between spouses, log of household income, respondent and partner's log of individual income, respondent and partner's age and age squared, respondent and partner's education level, a dummy controlling for the presence of children, year fixed-effects, Land fixed-effects and individual fixed-effects (columns 4,5 and 6).

Finally, Figure E4 shows that within Berlin, women who used to live (or whose mother used to live) in the GDR are more likely to be in paid-work than those who used to live 
in the FRG. The precise formulation of the aforementioned question was: "where have you lived before the German reunification (or, if you were born after, where has your mother lived)?". There are 914 women under 30 years old; 440 live in West Berlin and 474 in East Berlin. Among women over 29 years old, 1226 live in West Berlin and 1007 in East Berlin.

Figure E4: Female Participation in the Labor Market in Berlin
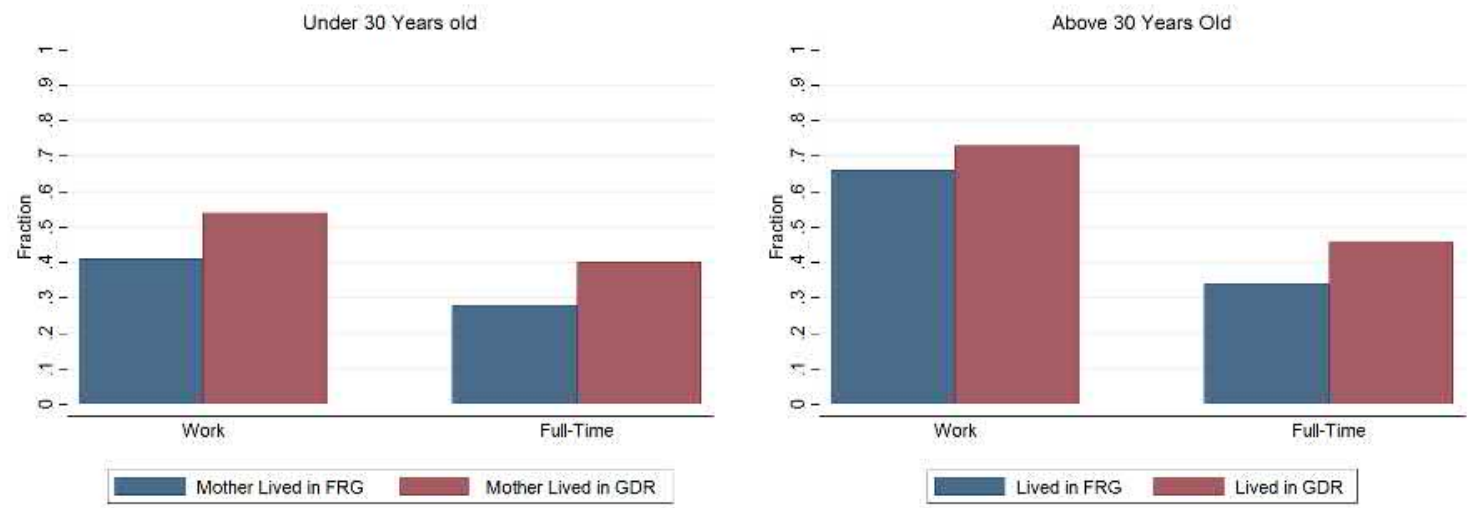

Notes: The left graph is restricted to women under 30 years old. The right graph is restricted to women above 30 years old. 


\section{E.15 Placebo Tests - Other Possible Focal Points}

This section displays placebo tests using alternative focal points rather than the point of equal income at $50 \%$. We use the most restrictive specification with individual fixedeffects for the three main outcomes. As we can see in Table E27, E28 and E29, the only focal point which triggers doing gender behaviors is at $50 \%$ for the three outcomes.

Table E27: Housework Time and Female Relative Income. Placebo Alternative Thresholds

Dependent variable: Woman's Housework Time (hours per day)
(1)
$(2)$
(3)
(4)

Wife Earns More than 10\%

$-0.03$

$(0.06)$

Wife Earns More than $10 \% *$ East $\quad 0.05$

Wife Earns More than 30\%

$-0.05$

$(0.04)$

Wife Earns More than $30 \% *$ East

Wife Earns More than 50\%

Wife Earns More than $50 \%$ *East

Wife Earns More than 70\% $0.24^{* * *}$

Wife Earns More than 90\%

0.16

Individual Fixed Effects

Individuals

Yes Yes

61046104

Yes

6104

Yes

6104

Yes $34205 \quad 34205 \quad 34205$ 34205

Notes: $* \mathrm{p}<0.1, * * \mathrm{p}<0.05, * * * \mathrm{p}<0.01$. The data comes from the German Socio-Economic Panel using all the waves from 1991 until 2012. The sample contains only dual earner married couples. Standard errors clustered at the individual level are given in parentheses. East is a dummy equals to 1 when both spouses lived in the former GDR before 1989. Controls: relative income, respondent and partner's log of individual income, log of household income, respondent and partner's age and age squared, respondent and partner's education level, a dummy controlling for the presence of children, year fixed-effects, Land fixed-effects and individual fixed-effects. 
Table E28: Marital Instability and Relative Income. Placebo Alternative Thresholds

Dependent Variable: Divorced within a 5-year time horizon

(2)

(3)

(4)

Wife Earns More than 10\%

$-0.01$

$(0.01)$

Wife Earns More than $10 \% *$ East $\quad-0.03$

Wife Earns More than 30\% $-0.01$

(0.01)

Wife Earns More than 30\%*East

0.00

(0.02)

Wife Earns More than 50\% $0.03^{* *}$

Wife Earns More than 50\%*East $-0.05^{* * *}$ (0.02)

Wife Earns More than 70\% 0.06 (0.05) $-0.05$ (0.05)

Wife Earns More than 90\%

Wife Earns More than 90\%*East

Individual Fixed Effects

Yes Yes Yes Yes Yes

Individuals

$2782 \quad 2782$

2782

2782

$13973 \quad 13973$

13973 13973

2782

Observations

Notes: $* \mathrm{p}<0.1,{ }^{*} \mathrm{p}<0.05, * * * \mathrm{p}<0.01$. The data comes from the German Socio- Economic Panel using all the waves from 1991 until 2012. The sample contains only dual earner married couples who divorced during the panel. Standard errors clustered at the couple level are given in parentheses. East is a dummy equals to 1 when both spouses lived in the former GDR before 1989 . Controls: respondent and partner's log of individual income, log of household income, respondent and partner's age and age squared, respondent and partner's education level, a dummy controlling for the presence of children, year fixed-effects, Land fixed-effects and couple fixed-effects. 
Table E29: Labor Force Participation and Female Relative Income. Placebo Alternative Thresholds

Woman out of the labor force in $T+1$

$\begin{array}{lllll}(1) \quad(2) \quad(3) & \text { (4) }\end{array}$

Wife Earns More than 10\%

$-0.02 * * *$

(0.01)

Wife Earns More than $10 \% *$ East

$0.04 * *$

$(0.02)$

Wife Earns More than 30\%

Wife Earns More than 30\%*East

Wife Earns More than 50\%*East

Wife Earns More than 70\%

Wife Earns More than $70 \% *$ East 0.01

$(0.00)$

$-0.00$

$(0.01)$

$0.01^{*}$
$(0.00)$
-0.01
$(0.01)$

Wife Earns More than 90\%

Wife Earns More than $90 \% *$ East

Individual Fixed Effects

Yes Yes Yes Yes Yes

Individuals

Notes: ${ }^{*} \mathrm{p}<0.1,{ }^{* *} \mathrm{p}<0.05, * * * \mathrm{p}<0.01$. The data comes from the German Socio-Economic Panel using all the waves from 1991 until 2012. Standard errors clustered at the individual level are given in parentheses. East is a dummy equals to 1 when both spouses lived in the former GDR before 1989. Controls: relative income, log of household income, respondent and partner's age and age squared, respondent and partner's education level, a dummy controlling for the presence of children, year fixed-effects, Land fixed-effects and individual fixed-effects. 


\section{E.16 Placebo Tests - Other Possible Divisions of Germany}

Table E30: Placebo Exercise: Alternative Geographical Divides

\begin{tabular}{|c|c|c|c|}
\hline \multicolumn{4}{|c|}{$\begin{array}{c}\text { Dependent variable }=1 \\
\text { if the coefficients on WifeEarnsMore and WifeEarnsMore }{ }^{*} \text { Group } 1 \\
\text { are both statistically significant, } \\
\text { and } 0 \text { otherwise }\end{array}$} \\
\hline One Eastern Lander in Group 1 & $\begin{array}{c}0.01 \\
(0.02)\end{array}$ & $\begin{array}{c}0.00 \\
(0.02)\end{array}$ & $\begin{array}{l}-0.00 \\
(0.01)\end{array}$ \\
\hline Two Eastern Landers in Group 1 & $\begin{array}{c}0.13^{* * *} \\
(0.02)\end{array}$ & $\begin{array}{c}0.08 * * * \\
(0.02)\end{array}$ & $\begin{array}{c}0.02 \\
(0.02)\end{array}$ \\
\hline Three Eastern Landers in Group 1 & $\begin{array}{c}0.38^{* * *} \\
(0.02)\end{array}$ & $\begin{array}{c}0.29 * * * \\
(0.02)\end{array}$ & $\begin{array}{c}0.12^{* * *} \\
(0.02)\end{array}$ \\
\hline Four Eastern Landers in Group 1 & $\begin{array}{c}0.74^{* * *} \\
(0.05)\end{array}$ & $\begin{array}{c}0.64^{* * *} \\
(0.04)\end{array}$ & $\begin{array}{c}0.38^{* * *} \\
(0.04)\end{array}$ \\
\hline Five Eastern Landers in Group 1 & $\begin{array}{c}1.00^{* * *} \\
(0.3)\end{array}$ & $\begin{array}{c}1.00^{* * *} \\
(0.25)\end{array}$ & $\begin{array}{c}1.00^{* * *} \\
(0.17)\end{array}$ \\
\hline Observations & 3003 & 3003 & 3003 \\
\hline
\end{tabular}

Notes: ${ }^{*} \mathrm{p}<0.1,{ }^{* *} \mathrm{p}<0.05,{ }^{* * *} \mathrm{p}<0.01$. This table tests all of possible divisions of the 15 German regions (excluding Berlin) into two groups of respectively 5 (Group 1) and 10 (Group 2) regions. We estimate equation 1 as in Table 3 column 6 , with the number of female housework hours as the independent variable, but changing the composition of the "East" dummy into a dummy for belonging in Group 1 rather than Group 2. We then define a dummy that equals 1 if the coefficients associated to WifeEarnsMore and WifeEarnsMore*East are statistically significant at the relevant thresholds. We regress this dummy on the number of Eastern Länder in Group 1 as independent variable using Ordinary Least Squares. The omitted category is 0 Eastern Länder in Group 1. Column 1 displays the probability that the coefficients of interest are significant at the $10 \%$ level; column 2 at the $5 \%$ level and column 3 at the $1 \%$ level. For instance, the cell in the third column and 3rd row shows that with 3 Eastern Länder in Group 1 rather than zero, the probability that the coefficients of interest are statistically significant at the $1 \%$ level increases by 12 percentage points. 


\section{F Attitudes}

\section{F.1 Descriptive Statistics}

This section displays descriptive statistics about attitudes with respect to work, success at work, career, marriage and family. The distributions are mostly concentrated on the modalities 1 and 2, representing the categories "very important" and "important". For this reason, the outcome variables in the article are dichotomized and equal 1 if the individual has considered a topic as very important and 0 otherwise.

Figure F1: Importance of Work for Satisfaction
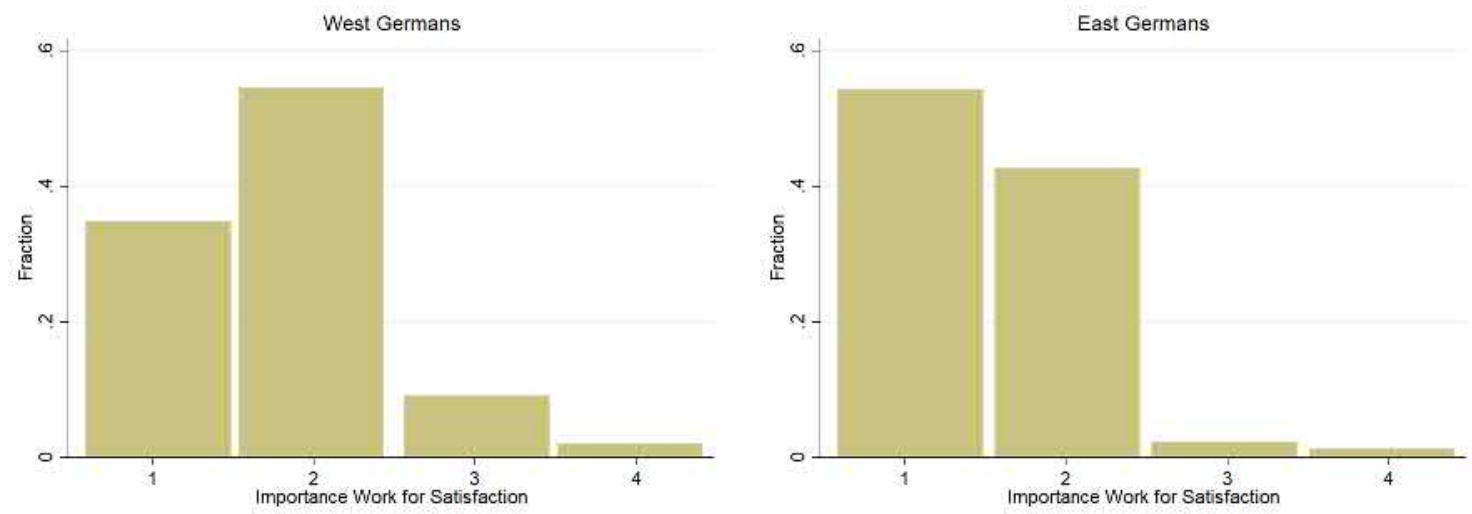

Figure F2: Importance of Success at Work for Satisfaction
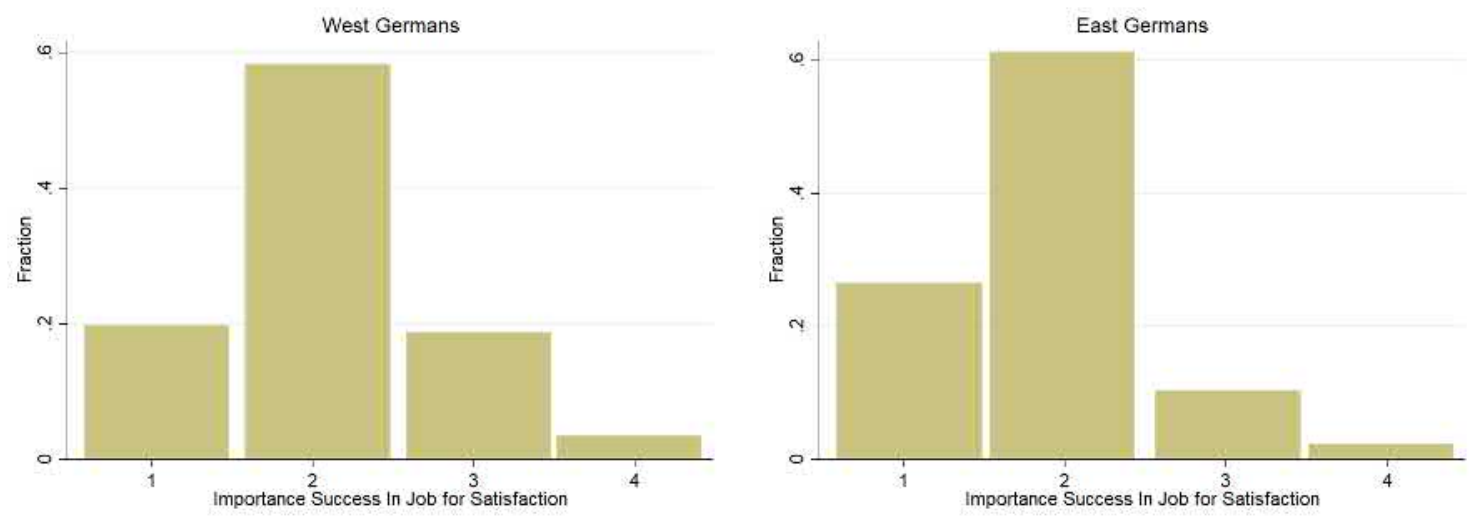
Figure F3: Importance of Career for Satisfaction
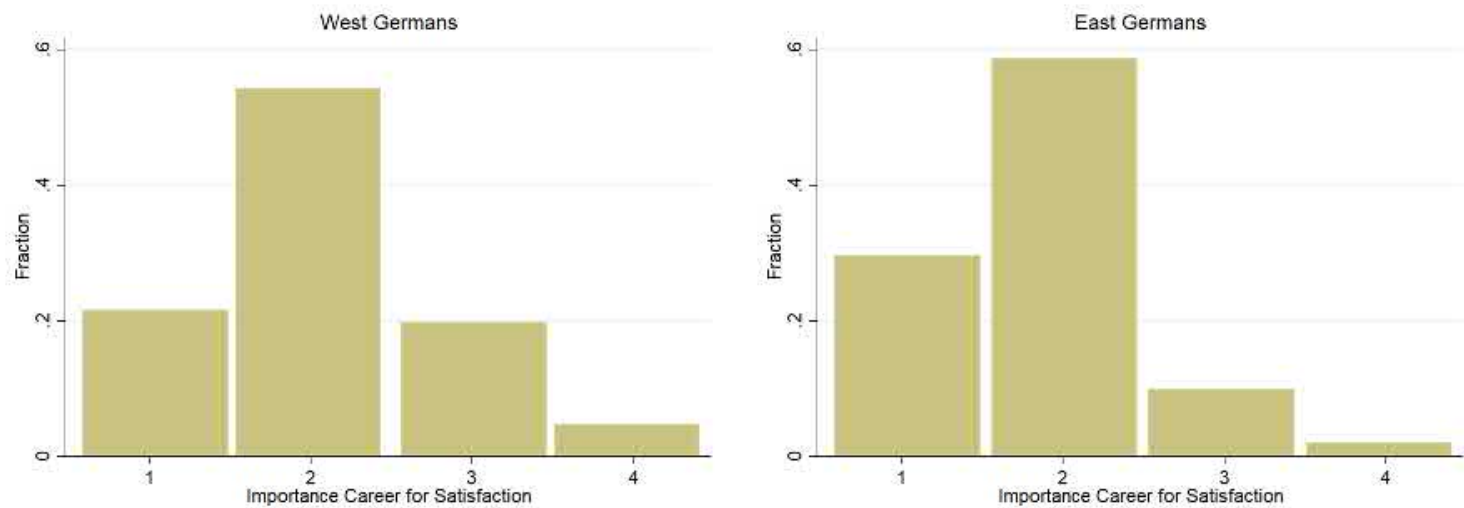

Figure F4: Importance of Marriage for Satisfaction
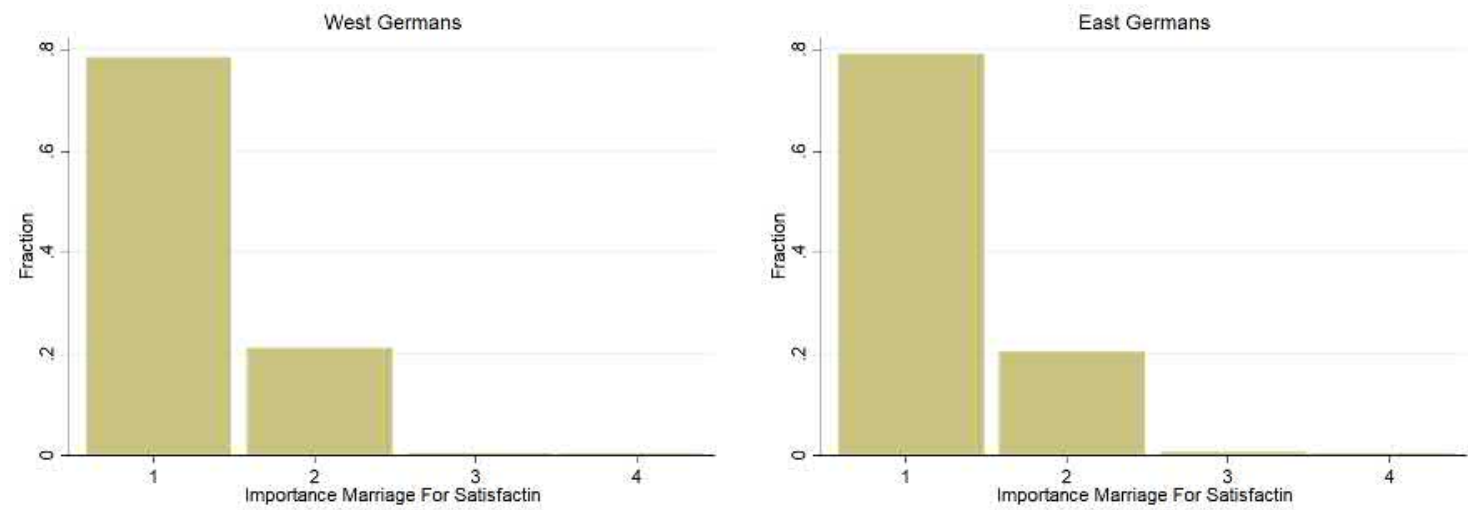

Figure F5: Importance of Family for Satisfaction
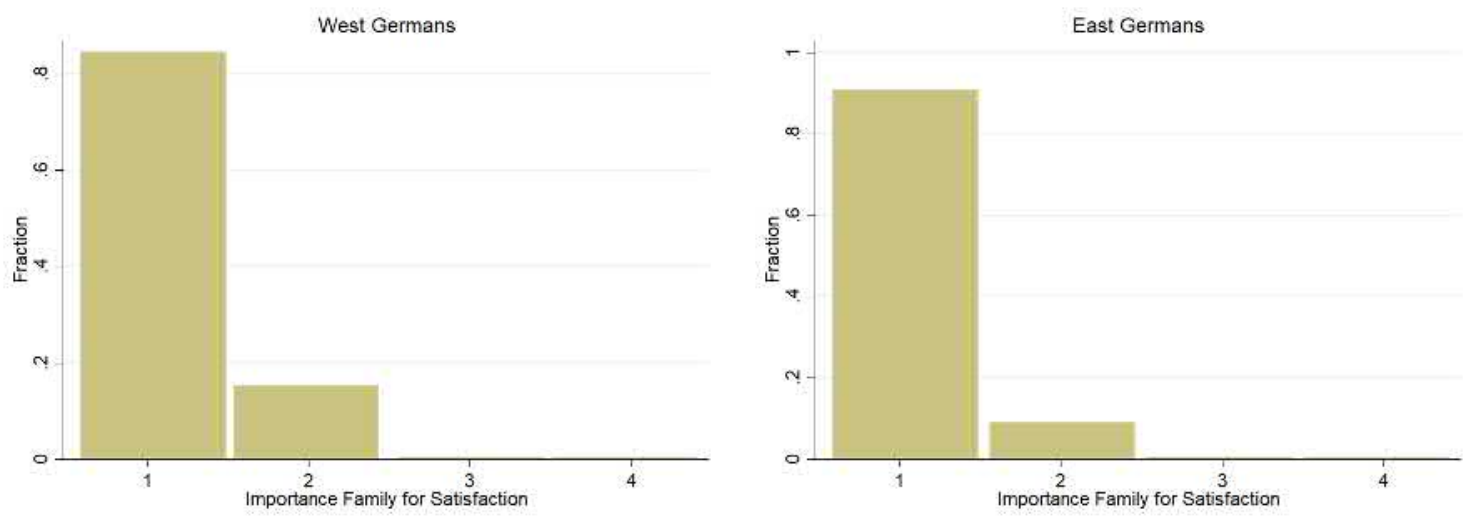

Notes: The data comes from the German Socio-Economic Panel using all the waves from 1991 until 2012. Descriptive statistics are based on the main sample: married couples with positive income. Eastern couples are those in which both spouses lived in GDR before 1989. Each bar displays the fraction of individuals who gave this answered. The answers are given on a 1-4 scale, 1 being very important, 2 important, 3 unimportant and 4 very unimportant. 


\section{F.2 Attitudes Per Cohort}

\section{Figure F6: Importance of Success at Work Per Cohort of East versus West Germans}

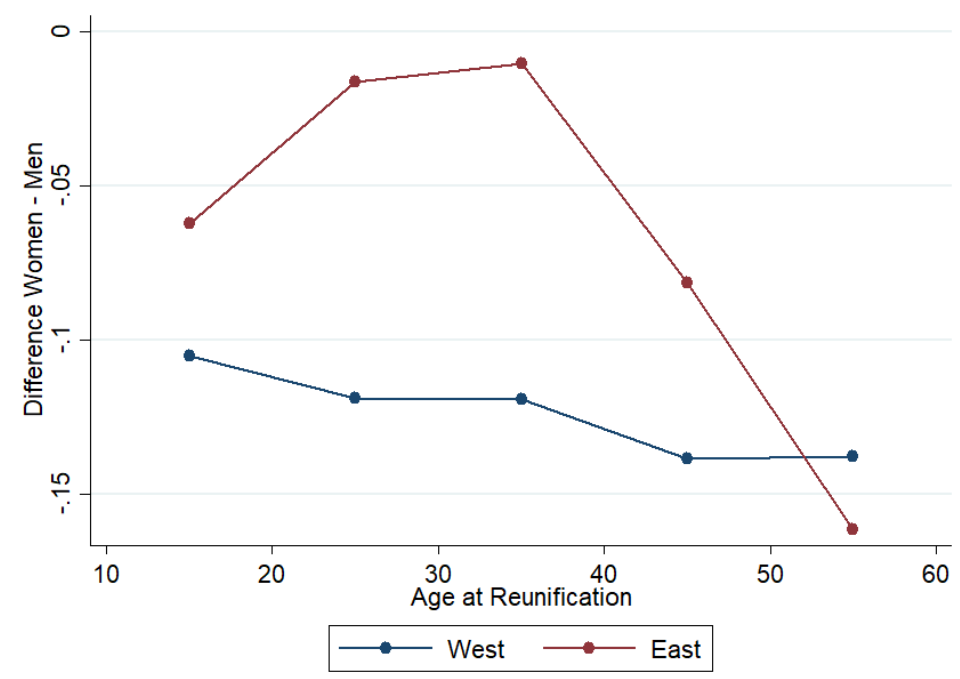

Notes: The data comes from the German Socio-Economic Panel using all the waves from 1991 until 2012. Sample: dual-earner married couples between 18 and 65 years of age. Eastern couples are those in which both spouses lived in GDR before 1989. Each bin represents the difference between men and women in importance for success at work (0-1 scale) within a window of individuals of similar age at reunification. The age windows are based on 10 years intervals.

Table F1: Attitudes to Success at Work per Cohort of East versus West Germans

Dependent Variable: How Important is Success at Work for your satisfaction?

$\begin{array}{lllll}(1) & (2) & (3) & \text { (4) }\end{array}$

\begin{tabular}{lccccc} 
Age at Reunification & $10-20$ & $20-30$ & $30-40$ & $40-50$ & $50-$ \\
\hline \multirow{2}{*}{ East } & 0.022 & 0.015 & 0.00 & $0.076^{* * *}$ & $0.155^{* * *}$ \\
& $(0.029)$ & $(0.019)$ & $(0.016)$ & $(0.027)$ & $(0.051)$ \\
Female & $-0.094^{* * *}$ & $-0.119^{* * *}$ & $-0.128^{* * *}$ & $-0.144^{* * *}$ & $-0.137^{* * *}$ \\
& $(0.025)$ & $(0.014)$ & $(0.013)$ & $(0.02)$ & $(0.035)$ \\
Female*East & 0.06 & $0.121^{* * *}$ & $0.132^{* * *}$ & $0.117^{* * *}$ & 0.0667 \\
& $(0.043)$ & $(0.028)$ & $(0.025)$ & $(0.036)$ & $(0.075)$ \\
Observations & & & & & \\
\hline
\end{tabular}

Notes: $* \mathrm{p}<0.1,{ }^{*} \mathrm{p}<0.05, * * * \mathrm{p}<0.01$. Probit marginal effects. The data comes from the German Socio-Economic Panel using all the waves from 1991 until 2012. The sample contains only married couples. Standard errors clustered at the individual level are given in parentheses. East is a dummy equals to 1 when both spouses lived in the former GDR before 1989. Controls: respondent and partner's age and age squared, respondent and partner's education level, a dummy controlling for the presence of children, a dummy representing whether the woman is working, a dummy representing whether the man is working and their interaction with the East dummy, year fixed-effects and Land fixed-effects. 